INSTITUTO DE PESQUISAS ENERGÉTICAS E NUCLEARES Autarquia associada à Universidade de São Paulo

\title{
DIRETRIZES PARA AVALIAÇÃO DO GASTO AMBIENTAL NO CICLO DO COMBUSTÍVEL NUCLEAR
}

\section{CINTIA NAGAKO KOMATSU}

Dissertação apresentada como parte dos requisitos para obtenção do Grau de Mestre em Ciências na Área de Tecnologia Nuclear Materiais.

Orientador:

Prof. Dr. Afonso Rodrigues de Aquino

São Paulo

2008 
INSTITUTO DE PESQUISAS ENERGÉTICAS E NUCLEARES Autarquia associada à Universidade de São Paulo

\title{
DIRETRIZES PARA AVALIAÇÃO DO GASTO AMBIENTAL NO CICLO DO COMBUSTÍVEL NUCLEAR
}

\author{
CINTIA NAGAKO KOMATSU
}

Dissertação apresentada como parte dos requisitos para obtenção do Grau de Mestre em Ciências na Área de Tecnologia Nuclear Materiais.

Orientador:

Prof. Dr. Afonso Rodrigues de Aquino

São Paulo

2008 
Dedico ao Sr. Munekasu, meu pai, que com sua presença espiritual me fortalece mais a cada dia 


\section{AGRADECIMENTOS}

Agradeço primeiramente a Deus, por me direcionar e iluminar o meu caminho, e jamais ter me abandonado, principalmente nos momentos mais difíceis.

Ao Professor Doutor e Orientador Afonso Rodrigues de Aquino, minha eterna gratidão pelos conselhos, sugestões, paciência e palavras de apoio durante a elaboração desse trabalho.

À Lucia Moreira, colaboradora desde o primeiro passo dessa caminhada, indicando-me ao meu Orientador.

Ao Centro Tecnológico da Marinha em São Paulo, onde sou funcionária e pude realizar minhas pesquisas e meus estudos aplicados na dissertação.

Aos colaboradores, que sempre estiveram dispostos a contribuir com suas informações: Ricardo Koji Yamamoto, Wagner Ezabella, Fábio José de Camargo Moreau, José Gonçalves Calvelo, Paulo Dias, André Luis Ferreira Marques, Paulo Queiroz, Silvia Vanni, Noriyuki Koishi, Eiko Taniguchi, Maria Euphrázia Martins, Eduardo Leitão da Silva, Abílio Benedito de Freitas, Sandra Sandoval, Sandra Mattiolo, Ângela Pereira, Ângela Cristina, Sandra Mara, Heitor Lobato Diaz Junior, llídio Marques, José Messias de Oliveira Neto, Luiz Antônio Abdalla de Moura, Lídia Xavier Lima, Claudeci Irineu e Maria Judite.

À Rosangela, que sempre me mostrou a importância da vida acadêmica e sempre esteve disposta a ajudar em qualquer situação.

À amiga Nilda Mariano, pelo companheirismo e grandes idéias na vida pessoal, profissional e acadêmica.

Aos colegas de trabalho, estudiosos e outros que, direta ou indiretamente estiveram ao meu lado nessa etapa de minha vida, em especial a Esthela Taniguchi, Ricardo Deccó e Sandra Tamura.

À minha querida mãe, meu irmão Edson e minha cunhada Néia pelo apoio incondicional.

E ao Almir Tahira pela paciência, apoio constante e pelas valiosas contribuições ao trabalho. 
"A realização não vem com a conquista dos objetivos traçados, mas sim no caminho percorrido até alcançá-lo." 


\title{
DIRETRIZES PARA AVALIAÇÃO DO GASTO AMBIENTAL NO CICLO DO COMBUSTÍVEL NUCLEAR
}

\author{
Cíntia Nagako Komatsu
}

\section{RESUMO}

Este estudo teve como objetivo estabelecer diretrizes para realização da Contabilidade Ambiental no Ciclo do Combustível Nuclear, tendo como estudo de caso a Unidade de Produção de Hexafluoreto de Urânio do Centro Tecnológico da Marinha em São Paulo. A ciência contábil, em sua vertente Contabilidade Ambiental, fornece um conjunto de ferramentas aptas a mensurar os esforços de proteção, conservação, recuperação e monitoramento do meio ambiente na etapa de Conversão, que vai do concentrado de urânio, o yellow cake, até a fabricação do hexafluoreto de urânio. Foram realizadas pesquisas, visitas, levantamento do banco de dados, entrevistas e consultas ao Relatório Preliminar de Análise de Segurança para se obter o porcentual dos gastos relativos à preservação ambiental que a unidade estudada investiu em relação ao total do gasto do empreendimento. E também foi realizada a valoração da área verde preservada, sendo possível o levantamento do Balanço Ambiental. 


\title{
GUIDELINES FOR EVALUATION OF THE ENVIRONMENTAL EXPENSE IN THE NUCLEAR FUEL CYCLE
}

\author{
Cintia Nagako Komatsu
}

\begin{abstract}
The main objective of this research is to establish guidelines to fit the Environment Account in the Nuclear Fuel Cycle, using as study of case the Uranium Hexafluoride Production Unit of Centro Tecnológico da Marinha in São Paulo. The Environment Accounting, branch of the accounting science, supply a source of tools capable to measure the protection efforts, the nature preservation, the environment monitoring and the recovering during all the Conversion phase (since the Uranium concentrated, the yellow cake, up to the Uranium hexafluoride production). It was performed several researches, visits to the Centre, databank creation, interviews and extensive consulting to the Preliminary Safety Report, in order to obtain the percentage of the total expenses related to environment protection in regarding to the total amount invested in the unit. It was also evaluated the total preserved green area making possible a preliminary environment accounting balance.
\end{abstract}




\section{SUMÁRIO}

Página

CAPA

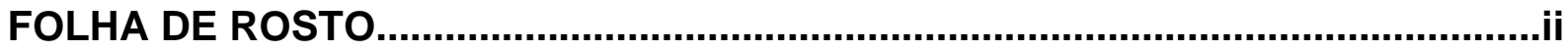

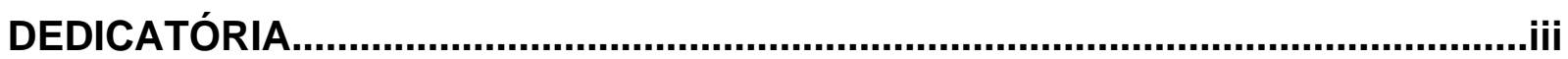

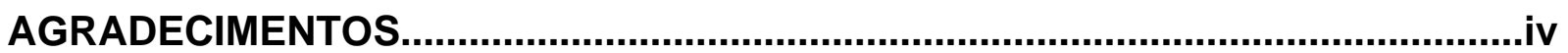

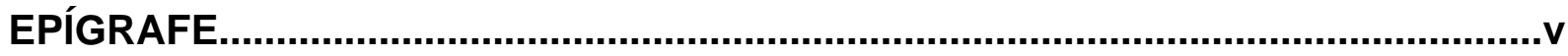

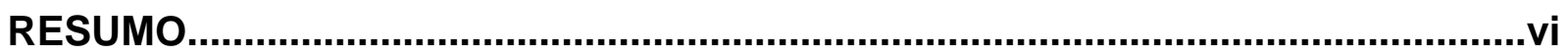

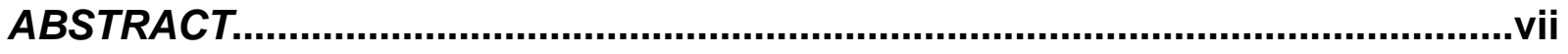

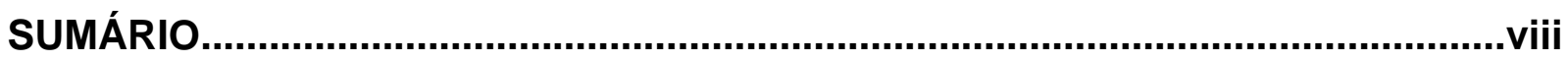

LISTA DE TABELAS

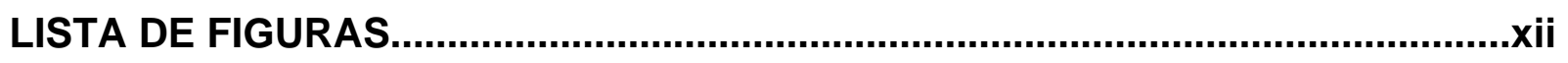

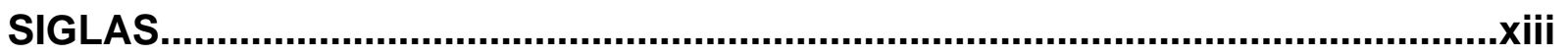

1 INTRODUÇÃO

2 OBJETIVO

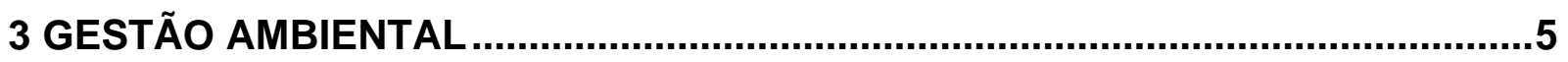

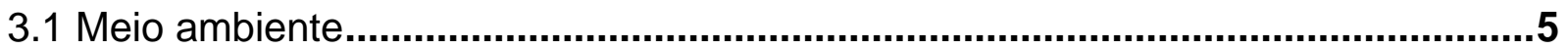

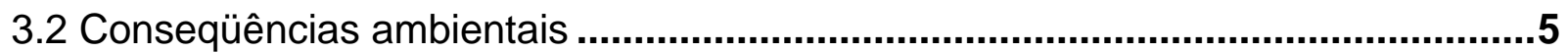

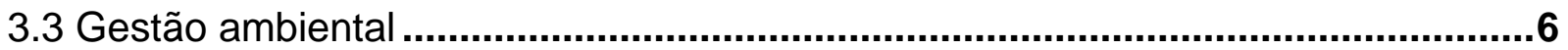

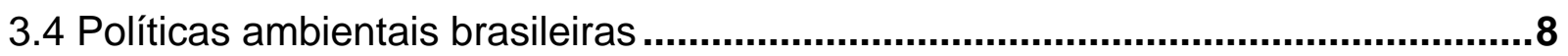

3.5 Legislação e normas ambientais na América Latina .............................................9

3.5.1 Destaque para o Brasil na América Latina .....................................................12

3.6 Gestão ambiental nas empresas.....................................................................14

3.7 A Contabilidade como ferramenta de gestão ambiental......................................15

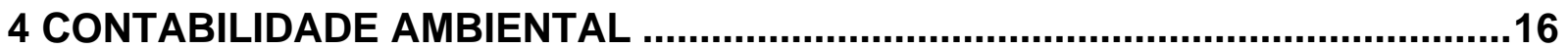

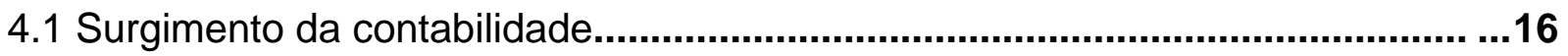

4.2 Objetivo da Contabilidade ................................................................................................17

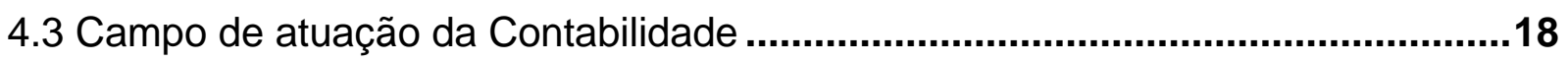

4.4 Relatórios contábeis ................................................................................................ 19

4.5 Terminologia .......................................................................................................................20

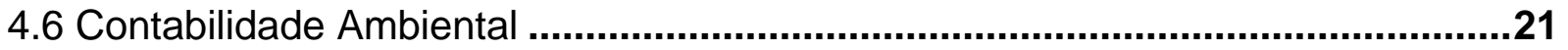

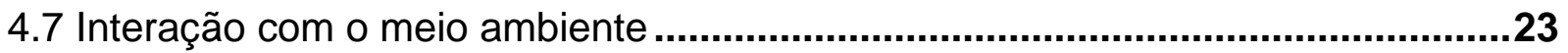

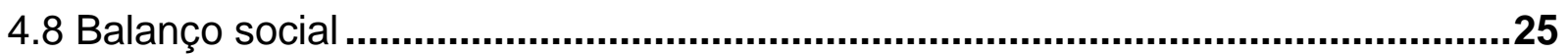




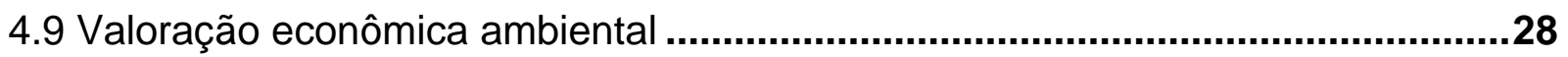

4.9.1 Métodos de valoração econômica ambiental ...................................................29

4.9.2 Externalidades e interiorização dos custos ambientais .....................................31

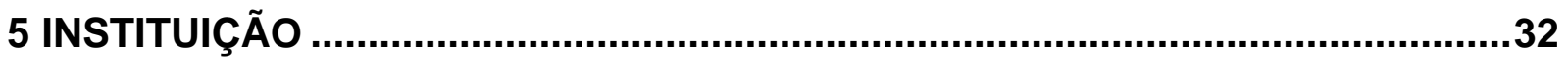

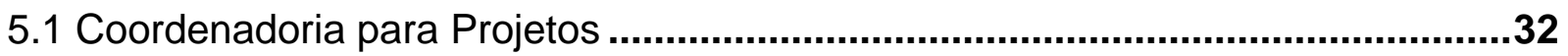

5.2 O Centro Tecnológico da Marinha em São Paulo .................................................33

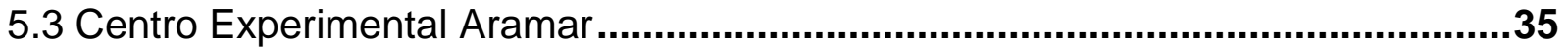

5.4 Unidade de Produção de Hexafluoreto de Urânio .................................................36

6 ENERGIA NUCLEAR

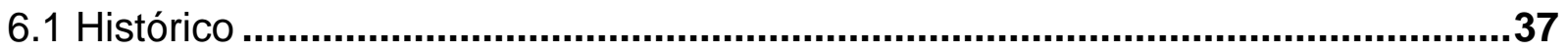

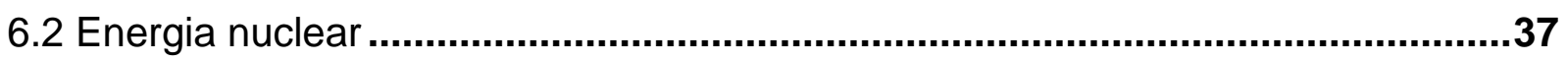

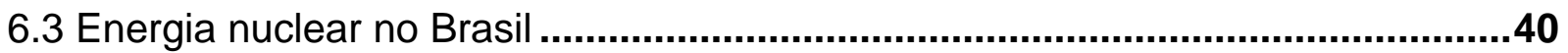

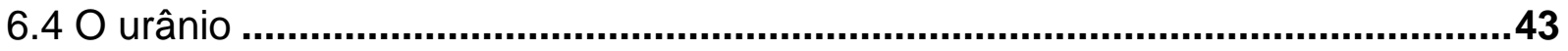

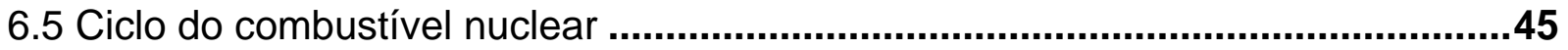

6.6 Unidade de Produção de Hexafluoreto de Urânio (USEXA) ................................51

6.7 Etapa de Conversão do ciclo do combustível nuclear........................................52

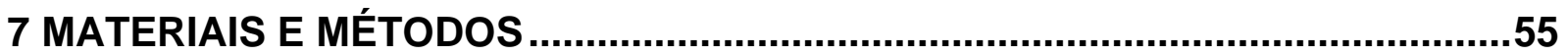

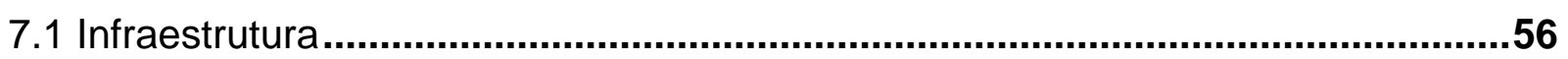

8 ESTUDO DE CASO

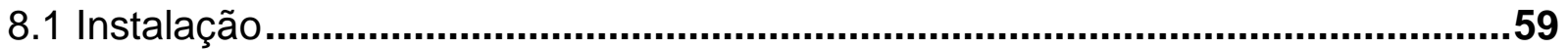

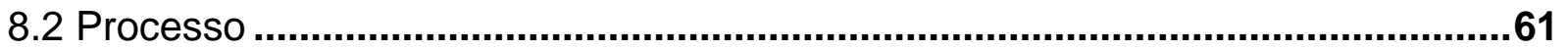

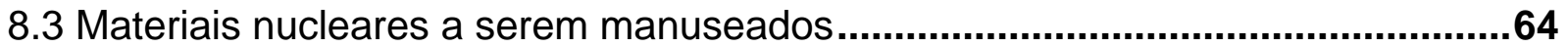

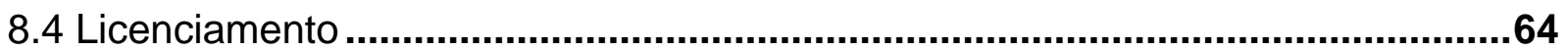

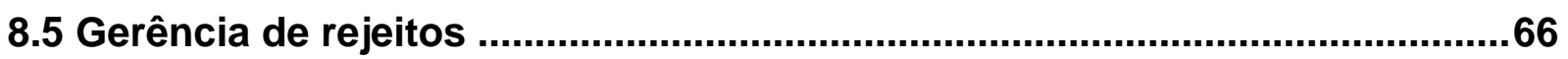

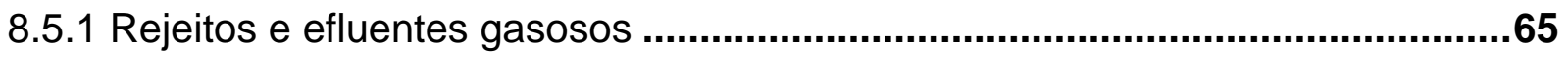

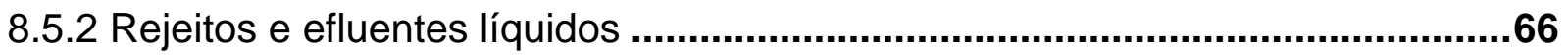

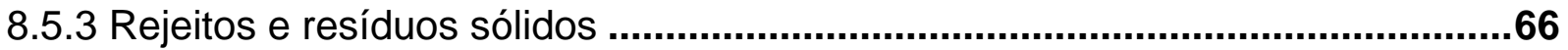

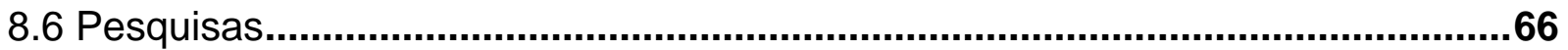

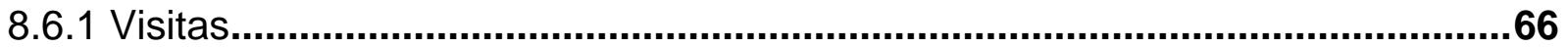

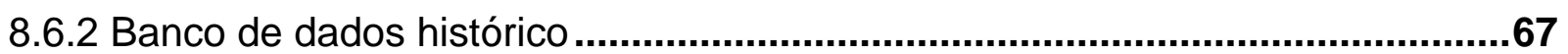

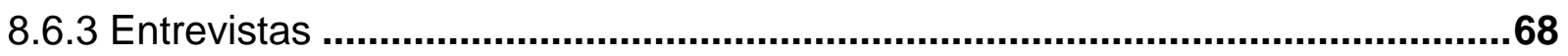

8.6.4 Relatório Preliminar de Análise de Segurança.................................................68

8.6.5 Gastos ambientais indiretos da USEXA .....................................................68

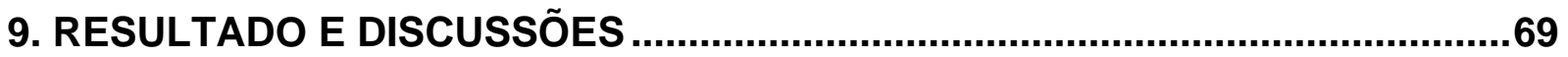




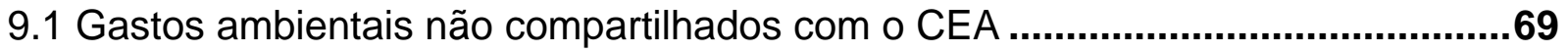

9.2 Gastos ambientais compartilhados ................................................................ 71

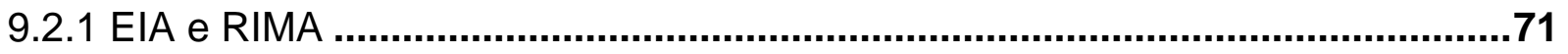

9.2.2 Sistema Integrado de Tratamento de Efluente de Aramar (SITEA) .................72

9.2.3 Lagoa de Monitoração....................................................................................73

9.2.4 Estação de tratamento de esgoto (ETE) ............................................................73

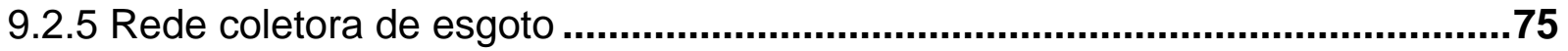

9.2.6 Obras de recuperação das áreas degradadas ...................................................75

9.2.7 Laboratório Radioecológico (LARE) ...........................................................76

9.2.8 Estação de observação meteorológica .........................................................77

9.2.9. Área Verde .....................................................................................................78

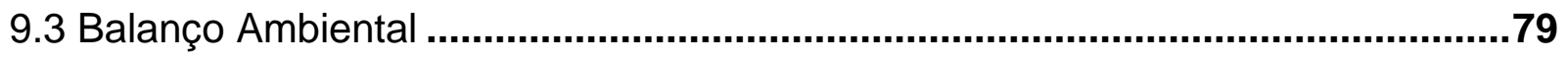

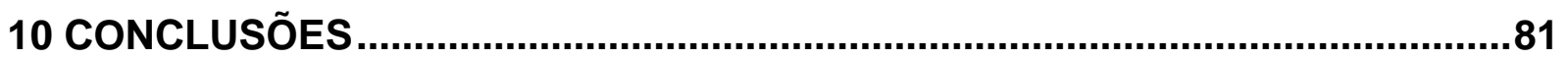

REFERÊNCIAS BIBLIOGRÁFICAS................................................................. 82

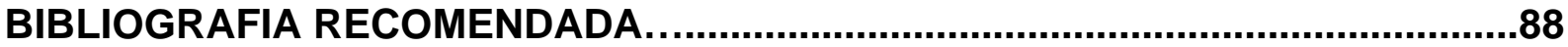




\section{LISTA DE TABELAS}

TABELA 1 - Legislação e Normas Ambientais de Países da América Latina...... 11

TABELA 2 - Informações sobre gastos com o meio ambiente .......................... 28

TABELA 3 - Comparação da produção de rejeitos de diferentes fontes de

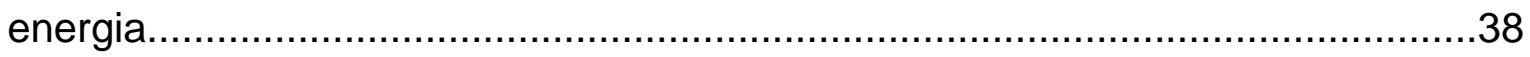

TABELA 4 - Balanço Ambiental da USEXA................................................ 80 


\section{LISTA DE FIGURAS}

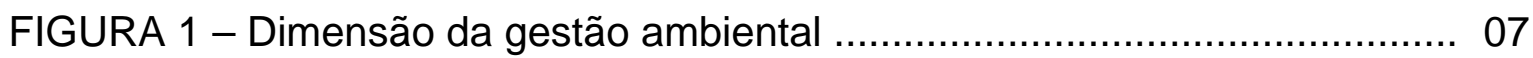

FIGURA 2 - Usuários internos e externos da Contabilidade ........................... 19

FIGURA 3 - Ramos da Contabilidade .................................................. 22

FIGURA 4 - Vertentes do Balanço Social .................................................. 26

FIGURA 5 - Vista aérea do CTMSP no campus do IPEN.............................. 33

FIGURA 6 - Principais atividades do CTMSP ......................................... 34

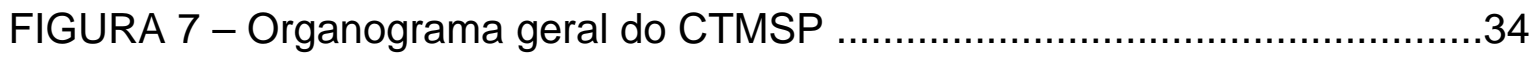

FIGURA 8 - Vista aérea do Centro Experimental Aramar................................ 35

FIGURA 9 - Vista aérea da USEXA …................................................... 36

FIGURA 10 - Comparação das fontes de energia ........................................ 39

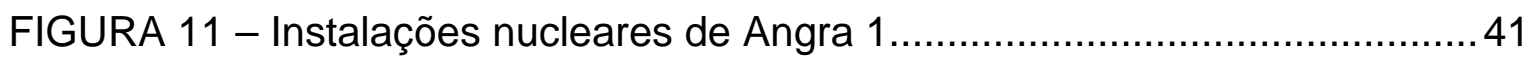

FIGURA 12 - Vista aérea das usinas nucleares de Angra dos Reis...................42

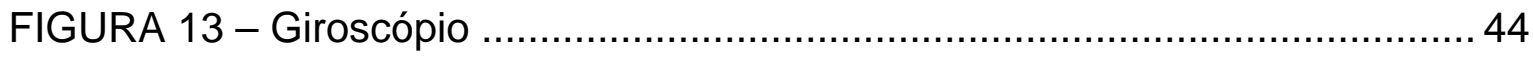

FIGURA 14 - Reservas brasileiras de urânio............................................ 44

FIGURA 15 - Diagrama esquemático do ciclo do combustível nuclear de

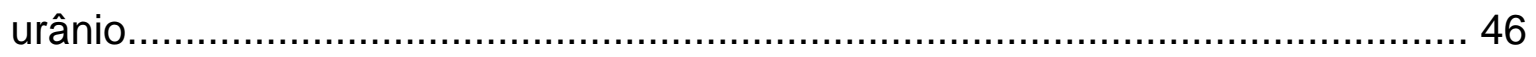

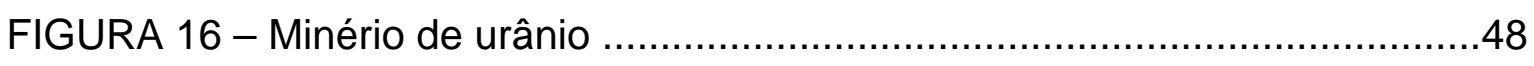

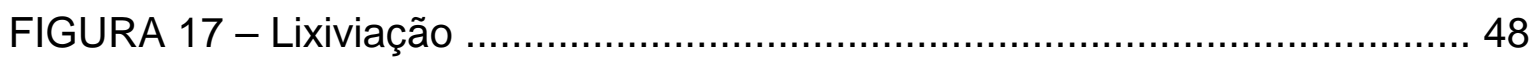

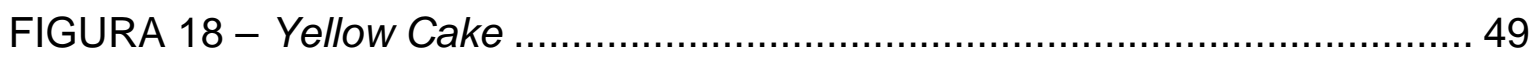

FIGURA 19 - Cilindro típico (modelo 48Y) para estocagem e transporte de UF.. 49

FIGURA 20 - Esquema de ultracentrifugação ........................................... 50

FIGURA 21 - Dióxido de urânio .......................................................... 50

FIGURA 22 - Pastilha de dióxido de urânio ............................................... 51

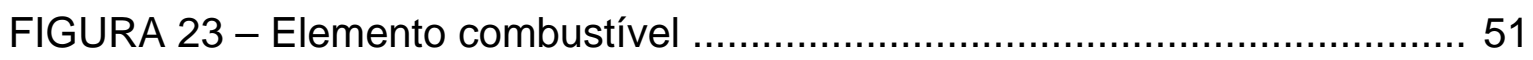

FIGURA 24 - Organograma da Coordenadoria do Ciclo do Combustível

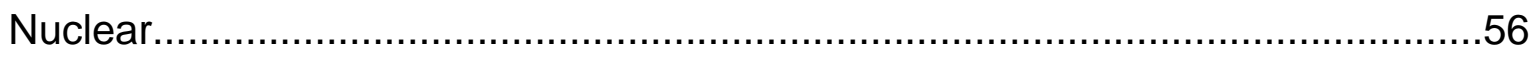

FIGURA 25 - Organograma da Superintendência Financeira ........................... 57

FIGURA 26 - Vista aérea das instalações da INB em Caetité-BA.......................58

FIGURA 27 - Diagrama simplificado de processo ......................................... 60 


\section{LISTA DE SIGLAS}

\begin{tabular}{|c|c|}
\hline CEA & Centro Experimental Aramar \\
\hline CETESB & Companhia de Tecnologia de Saneamento Ambiental \\
\hline CFC & Conselho Federal de Contabilidade \\
\hline $\mathrm{CM}$ & Comando da Marinha \\
\hline CNEN & Comissão Nacional de Energia Nuclear \\
\hline CNPE & Comissão Nacional de Política Energética \\
\hline CNPq & Conselho Nacional de Desenvolvimento Científico e Tecnológico \\
\hline $\mathrm{CO}_{2}$ & Gás Carbônico \\
\hline CONAMA & Conselho Nacional do Meio Ambiente \\
\hline COPESP & Coordenadoria para Projetos Especiais \\
\hline CTMSP & Centro Tecnológico da Marinha em São Paulo \\
\hline DAA & Disposição a Aceitar \\
\hline DAP & Disposição a Pagar \\
\hline DGMM & Diretoria Geral de Materiais da Marinha \\
\hline DUA & Diuranato de Amônio \\
\hline DVA & Demonstração do Valor Adicionado \\
\hline EIA & Estudos de Impacto Ambiental \\
\hline EPE & Empresa de Pesquisas Energéticas \\
\hline ETE & Estação de Tratamento de Esgoto \\
\hline $\mathrm{F}_{2}$ & Flúor \\
\hline FEEMA & Fundação Estadual de Engenharia do Meio Ambiente \\
\hline FINEP & Financiadora de Estudos e Projetos \\
\hline $\mathrm{HF}$ & Ácido Fluorídrico \\
\hline IBAMA & Instituto Brasileiro do Meio Ambiente e dos Recursos Naturais Renováveis \\
\hline IBOPE & Instituto Brasileiro de Opinião Pública e Estatística \\
\hline IBRACON & Instituto dos Auditores Independentes do Brasil \\
\hline INB & Indústrias Nucleares do Brasil \\
\hline IPEA & Instituto de Pesquisa Econômica Aplicada \\
\hline IPEN & Instituto de Pesquisas Energéticas Nucleares \\
\hline ISO & Organização Internacional para Padronização \\
\hline kw & Kilowatts \\
\hline LABCHOQUE & Laboratório de Choques, Vibração e Ruído \\
\hline
\end{tabular}




\begin{tabular}{|c|c|}
\hline LABGENE & Laboratório de Geração Núcleo-Elétrica \\
\hline LABMAT & Laboratório de Materiais Cerâmicos e Nucleares \\
\hline LAC & Laboratório de Aferição e Calibração \\
\hline LACEM & Laboratório de Compatibilização Eletromagnética \\
\hline LARE & Laboratório Radioecológico \\
\hline LATEP & Laboratório de Testes de Equipamento de Propulsão \\
\hline LEI & Laboratório de Enriquecimento Isotópico \\
\hline MOX & Mescla de Óxido Combustível \\
\hline MW & Megawatt \\
\hline NBC & Normas Brasileiras de Contabilidade \\
\hline NPA & Norma e Procedimento de Auditoria \\
\hline NTU & Nitrato de Uranilo \\
\hline OFCEL & Oficina de Fabricação de Componentes Eletromecânicos \\
\hline OFCESP & Oficina de montagem de Componentes Especiais \\
\hline OFCOM & Oficina de Fabricação de Componentes Mecânicos \\
\hline OFMEPRE & Oficina Mecânica de Precisão \\
\hline OFMEQ & Oficina de Montagem de Equipamento \\
\hline OFTUB & Oficina de Fabricação de Tubulação \\
\hline OM & Organização Militar \\
\hline ONU & Organização das Nações Unidas \\
\hline OPEP & Organização dos Países Exportadores de Petróleo \\
\hline $\mathrm{Pu}$ & Plutônio \\
\hline PWR & Reator de Água Pressurizada (Pressurzed Water Reactor) \\
\hline RIMA & Relatório de Estudos de Impacto Ambiental \\
\hline RPAS & Relatório Preliminar de Análise de Segurança \\
\hline SGA & Sistema de Gestão Ambiental \\
\hline SIAFI & Sistema Integrado de Administração Financeira do Governo Federal \\
\hline SICAF & Sistema de Cadastro de Fornecedores \\
\hline SISNAMA & Sistema Nacional do Meio Ambiente \\
\hline SITEA & Sistema Integrado de Tratamento de Efluentes de Aramar \\
\hline TBP & Fosfato de tri-n-butila \\
\hline$U$ & Urânio \\
\hline $\mathrm{UF}_{4}$ & Tetrafluoreto de Urânio \\
\hline $\mathrm{UF}_{6}$ & Hexafluoreto de Urânio \\
\hline
\end{tabular}


$\mathrm{UO}_{2}$

$\mathrm{UO}_{3}$

USEXA

USIDE
Dióxido de Urânio

Trióxido de Urânio

Unidade de Produção de Hexafluoreto de Urânio

Unidade Industrial para Enriquecimento de Urânio 


\section{INTRODUÇÃo}

Desde os primórdios a humanidade utilizou os recursos naturais sem a preocupação de que esses se esgotassem. Tudo era abundante e farto, e o que era descartado no meio ambiente não gerava reflexos negativos.

Mas, a partir de meados do Século XVIII, com a Revolução Industrial na Europa, foi notado o aumento da poluição:

- As indústrias começaram a produzir objetos de consumo em grande escala e a fabricar embalagens descartáveis, elevando o volume e a diversidade de resíduos;

- Naquela época, indústrias e residências queimavam carvão para produção de energia depositando na atmosfera toneladas de poluentes e, nesse mesmo contexto, favorecendo a formação da chuva ácida, a qual é composta de diferentes ácidos capazes de provocar danos nas plantas e solos;

- Com a industrialização ocorreu um aumento no volume de detritos despejados nas águas, superando a capacidade de auto-limpeza dos rios e oceanos.

De acordo com Moura, a percepção de que a degradação ambiental já estava passando a causar graves problemas de saúde pode ser evidenciada na Inglaterra, região de Londres, por um evento ocorrido em dezembro de 1952. Neste período, grande parte das indústrias, sobretudo as de geração de energia elétrica para residências, usavam carvão que, em sua queima, sem posterior tratamento dos gases, emitiam grandes quantidades de enxofre e material particulado na atmosfera, o que ocasionou um fenômeno batizado como "smog", ou seja, contração das palavras smoke e fog (Moura, 2002).

Para agravar a situação mundial, as atividades industriais, os aglomerados urbanos e a expansão da agricultura só vêm aumentando, ocasionando o crescimento exponencial do nível de poluição. O consumo de recursos naturais é cada vez maior, gerando grandes preocupações com o esgotamento das reservas. Deve ser levado em consideração o crescimento populacional, que mantido nos atuais níveis, sinaliza com a inexistência dos recursos para futuras gerações. Estudos demonstram que, há 2000 anos, a população era constituída por 300 milhões de pessoas, passaram-se 1600 anos 
para dobrar o número de habitantes e, por volta de 1800, a população atingiu o primeiro bilhão. Em 1930, já eram dois bilhões, em 1960 chegou-se ao terceiro bilhão. E, atualmente, são seis bilhões de habitantes. Previsões realizadas pela Organização das Nações Unidas (ONU) apontam que em 2050 a população mundial será de 10.9 bilhões de pessoas. Esse acréscimo acontecerá mais nos países que são afetados pela degradação do solo, pela escassez de água e por enormes dificuldades para fornecer serviços básicos a seus habitantes. Isto é motivo de graves preocupações com a própria sobrevivência, de acordo com (Tinoco \& Kraemer, 2004).

As empresas sentem a obrigação de incorporar aos seus objetivos de obtenção de lucros a responsabilidade social, a qual abrange o bem-estar da população em sua integridade, devido a crescente e assustadora degradação ambiental. A inclusão da proteção ao ambiente entre os objetivos das organizações modernas amplia substancialmente o escopo da contabilidade. Administradores, executivos e empresários introduzem os programas de reciclagem, medidas para poupar energia e outras inovações ecológicas; essas práticas se espalham e vários pioneiros de negócios desenvolvem sistemas abrangentes de contabilidade de cunho ecológico, objetivando a sustentabilidade empresarial (Tinoco \& Kraemer, 2004).

Algumas atividades operacionais de empresas que afetam o meio ambiente são destacadas a seguir e devem ser objetos de mensuração da contabilidade:

- Mineração de carvão: a disposição não adequada de rejeitos, água acidificada de drenagem das minas, água de arraste e lixiviação resultantes das fases da extração e do beneficiamento do carvão bruto provocam impactos ambientais negativos na atmosfera, no solo e nas águas de superfície e subterrânea.

- Produção de cal: contamina o meio ambiente por meio de organoclorados, composto de carbono contendo cloro, entre os quais as dioxinas, que são uma das substâncias químicas altamente tóxicas e cancerígenas, e o mercúrio que pode afetar o sistema nervoso.

- Cana-de-açúcar: as queimadas nas colheitas provocam problemas ambientais, principalmente na contaminação do ar. 
- Indústria petrolífera: impactos ambientais nas atividades de exploração de petróleo, como emissões e geração de resíduos.

A contabilização dos eventos ambientais pode ser aplicada em qualquer ramo de atividade, inclusive, na área nuclear. A energia nuclear é considerada uma forma "limpa" de energia, pois durante a sua geração para a produção de energia elétrica, não há emissão de gases na atmosfera, principalmente do gás carbônico $\left(\mathrm{CO}_{2}\right)$, ou seja, não colaborando, assim, com o efeito estufa. Por outro lado, o grande problema é a radioatividade, que não é percebida pelos órgãos dos humanos, e que, por isso, há necessidade de proteção, tais como: blindagens e cuidados especiais durante a operação da usina. Com isso, se evita acidentes que poderiam levar ao vazamento de material e contaminação do meio ambiente. O ciclo de produção do combustível nuclear requer cuidados devido a existência de elementos tóxicos. Porém, sabendo desses riscos, as instalações nucleares são projetadas com as condições de segurança exigidas. Outro problema são os rejeitos e resíduos radioativos. Existe a formação de uma quantidade maior na fase de mineração e de produção de yellow cake, embora estes sejam de baixa atividade, a preocupação está nos produtos de fissão resultantes da queima do combustível durante a operação do reator, que possuem longa vida e emitem radiação, necessitando de estocagem em condições especiais de segurança durante centenas ou milhares de anos (Moura, 2002).

A contabilidade de todos os gastos incorridos pelas usinas nucleares, para não gerar impactos negativos ao meio ambiente é demonstrada através do Balanço Social, instrumento que permite dar transparência às atividades da empresa, fornecendo indicadores de desempenho econômico, social e ambiental.

A Ciência Contábil, em sua vertente Contabilidade Ambiental, fornece um conjunto de ferramentas aptas a mensurar os esforços de proteção, conservação, recuperação e monitoração do meio ambiente no ciclo do combustível nuclear, que compreende várias etapas do processo industrial (Prospecção, Beneficiamento, Purificação, Conversão, Separação Isotópica, Fabricação do Elemento Combustível, Reprocessamento do Combustível Irradiado e Tratamento dos Rejeitos Radioativos). 


\section{OBJETIVO}

O objetivo geral deste trabalho foi estabelecer diretrizes para realização da Contabilidade Ambiental nas diferentes etapas do processamento do urânio, compreendidas entre a dissolução do concentrado de urânio (yellow cake) e a produção de hexafluoreto de urânio.

Para isto, teve como objetivo específico realizar um estudo tomando por base a Unidade de Produção de Hexafluoreto de Urânio (USEXA), do Centro Tecnológico da Marinha em São Paulo, para identificação e quantificação dos gastos ambientais. 


\section{GESTÃO AMBIENTAL}

\subsection{Meio ambiente}

O meio ambiente é o conjunto de elementos bióticos (organismos vivos) e abióticos (energia solar, solo, água e ar) que integram a camada da Terra chamada biosfera, sustentáculo e lar dos seres vivos (Tinoco \& Kraemer, 2004).

Mas é percebido que a perspectiva futura sobre o meio ambiente não é muito clara. A sociedade deve reconhecer que os recursos são finitos. O impacto do homem sobre a natureza tem sido comparado por alguns cientistas às grandes catástrofes do passado geológico da Terra. A humanidade deve reconhecer que agredir o meio ambiente coloca em perigo a sobrevivência de sua própria espécie.

\subsection{Conseqüências ambientais}

Tinoco \& Kraemer descrevem um breve histórico das conseqüências ambientais decorrentes de atividades humanas.

- Anos 30: uma espessa névoa cobriu uma área industrial na Bélgica, ocasionando às pessoas tosse, dores no peito, dificuldades de respirar, irritação na mucosa nasal e nos olhos. Ao final de cinco dias, cerca de 70 pessoas morreram e centenas de outras ficaram enfermas. As causas da grande concentração de poluentes no ar, que ocasionou as mortes e doenças, foram as emissões atmosféricas das indústrias em condições climáticas desfavoráveis.

- Anos 50: no Japão um acidente com derramamento de mercúrio contaminou a Baía de Minamata, ocasionando cerca de 700 mortos e 9.000 doentes crônicos. Com a ingestão de peixes contaminados começaram a ocorrer em pequenas comunidades locais, casos de distúrbios nervosos, convulsões, perda da coordenação motora e outros sintomas relacionados ao sistema neurológico.

- Anos 70: um grande incêndio numa indústria de pesticida em Seveso, na Itália, originou uma pequena nuvem branca que continha dioxina, que logo foi disseminada pela atmosfera na região. Cinco dias mais tarde, as crianças começaram a aparecer com pontos vermelhos e borbulhas na pele, além de sofrerem problemas renais e vômitos constantes. Por causa 
da contaminação milhares de animais morreram e outros foram sacrificados para evitar a entrada de dioxina na cadeia alimentar.

- Anos 80: Em 1984, na Índia, ocorreu um vazamento acidental de gás metil isocianato, um produto intermediário na fabricação de inseticidas, nas instalações da Union Carbide, provocando a morte de aproximadamente 4.000 pessoas. Outro acidente da década de 80 foi a de Chernobyl, em 1986, considerado o pior acidente da histórica da energia nuclear, por ter produzido uma nuvem de radioatividade que se espalhou por mais de um continente.

- Anos 90: uma grande nuvem de fumaça, misturada com uma densa neblina, que cobriu o sudeste asiático devido a incêndio nos bosques, foi a causadora da queda de um avião em setembro de 1997. Os incêndios foram provocados pela queima de enorme quantidade de turfa e pelas altas temperaturas desenvolvidas neste processo.

- Ano 2000: em janeiro deste ano, um duto avariado da Petrobrás permitiu que 1,3 milhões de litros de óleo contaminassem um dos maiores cartões postais do país, a Baía de Guanabara. O óleo se esparramou por uma faixa de três quilômetros, atingindo praias da ilha de Paquetá e a Área de Proteção Ambiental de Guapimirim, a reserva mais importante da Baía de Guanabara (Tinoco \& Kraemer, 2004).

Os danos ambientais nas gerações de hoje e seus reflexos para as gerações futuras fazem com que essas questões desconheçam fronteiras, tornando-se globalizado, e chamando cada vez mais a atenção de todos. Os problemas ambientais relativizam o tempo e o espaço ao atingir indiscriminadamente diferentes gerações de incontáveis países.

\subsection{Gestão ambiental}

O processo de gestão ambiental inicia-se, segundo Philippi Jr, quando se promovem adaptações ou modificações no ambiente natural, de maneira a adequá-lo às necessidades individuais ou coletivas (Philippi Jr et al, 2004).

Gestão ambiental é como diretrizes e atividades administrativas ou operacionais, por exemplo: planejamento, direção, controle e alocação de recursos para se obter efeitos positivos sobre o meio ambiente, com a redução ou eliminação dos problemas causados pela ação humana (Barbieri, 2007). 
A gestão ambiental pode ser considerada em três dimensões, como mostra a FIG. 1:

- Espacial: área na qual se espera que as ações tenham eficácia.

- Temática: questões às quais as ações se destinam.

- Institucional: agentes que tomaram as iniciativas de gestão.

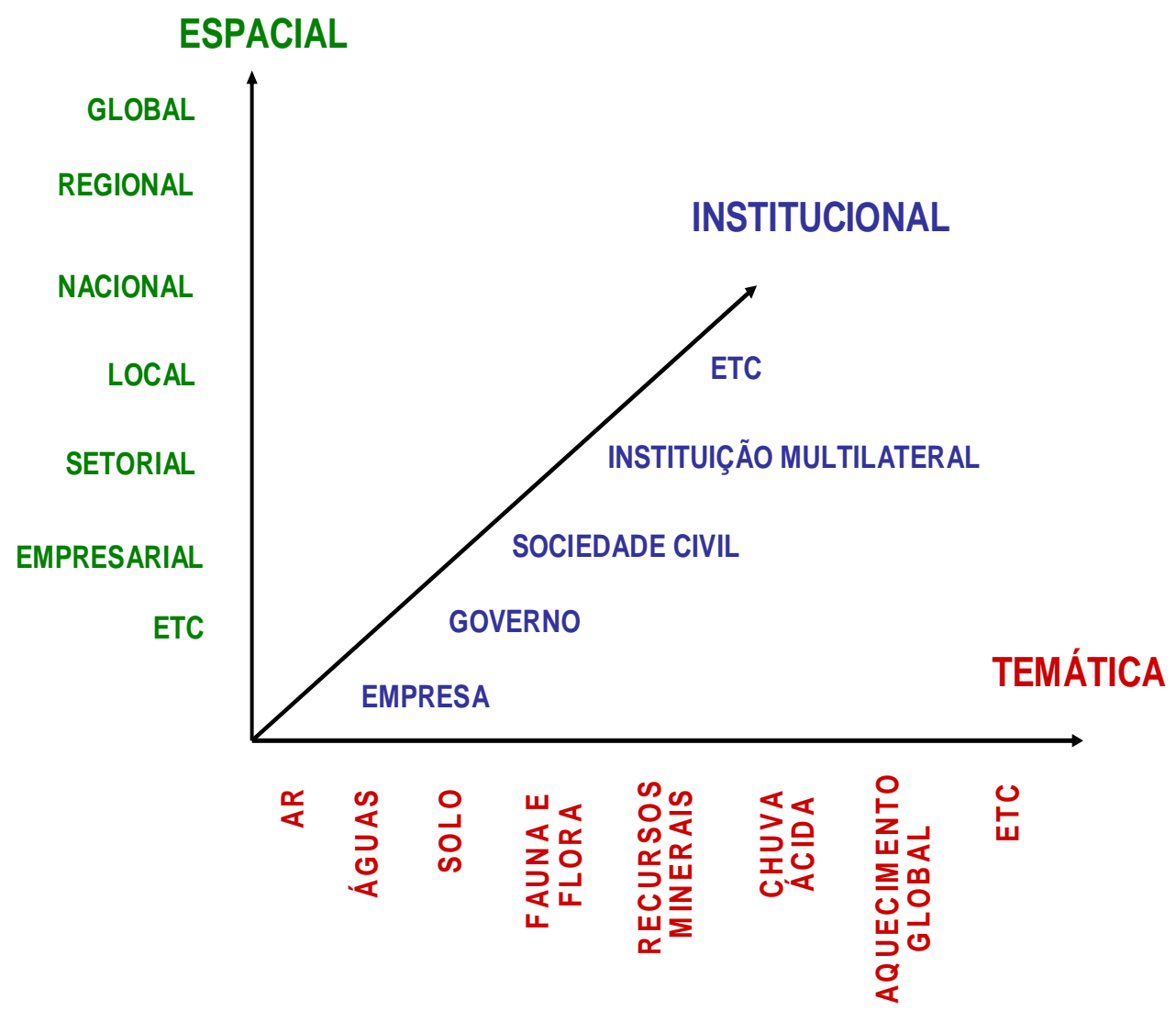

FIGURA 1 - Dimensão da gestão ambiental Fonte: Barbieri, 2007

Para Barbieri a solução dos problemas ambientais, ou sua diminuição, consiste em atitudes dos administradores, gerentes, empresários que precisam incluir o meio ambiente em suas decisões e adotar concepções administrativas e tecnológicas que colaborem para a sustentabilidade do planeta. As preocupações ambientais dos empresários são influenciadas por três forças que interagem entre si: o governo, a sociedade e o mercado. Se não existissem pressões da 
sociedade e do governo as empresas não se envolveriam nas questões ambientais. As legislações ambientais normalmente são frutos da percepção de problemas ambientais por parte de segmento da sociedade que, por sua vez, pressiona os agentes estatais para solucioná-los (Barbieri, 2007).

A gestão ambiental em qualquer nível se efetiva por meio da implementação de diversos instrumentos de políticas ambientais públicas e privadas. E o governo, como órgão máximo regulador, deve harmonizar as políticas relacionadas à proteção ambiental.

\subsection{Políticas ambientais brasileiras}

O Brasil, atualmente, possui leis ambientais muito severas para os que descuidam da questão ambiental. Existem casos de multas milionárias para empresas que causam crimes ambientais, até mesmo responsabilizando dirigentes empresarias e órgãos públicos. Percebe-se uma atuação mais rígida dos agentes governamentais na área ambiental, na forma de fiscalização, denúncia e punição de ações que influenciem de forma negativa o meio ambiente.

Observa-se uma evolução em relação aos assuntos durante a história brasileira, mais precisamente com os problemas relativos à poluição após 1960:

- Até 1970 a poluição era sinônimo de progresso;

- Após 1972 tem-se a Conferência de Estocolmo e a preocupação ambiental se torna mais intensa;

- 1973: Criação da Secretaria Especial do Meio Ambiente;

- 1973: Criação da CETESB (Companhia de Tecnologia de Saneamento Ambiental);

- 1975: Criação da FEEMA (Fundação Estadual de Engenharia do Meio Ambiente);

- Após 1980 adoções de políticas integradas;

- 1981: Criação do SISNAMA (Sistema Nacional do Meio Ambiente) e CONAMA (Conselho Nacional do Meio Ambiente);

- 1988: Constituição Federal: Art. 225 Todos têm direito ao meio ambiente ecologicamente equilibrado, bem de uso comum do povo e essencial à 
sadia qualidade de vida, impondo-se ao Poder Público e à coletividade o dever de defendê-lo e preservá-lo para as presentes e futuras gerações.

- 1998: Lei de Crimes Ambientais ou a Lei da Natureza, a maior novidade é a responsabilidade penal da empresas.

- 2003: Criação do Ministério do Meio Ambiente. Uma autarquia do governo do Brasil, criado pelo Decreto $N^{\circ}$. 4.755, de 20 de Junho, assinado pelo vice-presidente da República, José Alencar Gomes da Silva, que aprovou a Estrutura Regimental e o Quadro Demonstrativo dos Cargos em Comissão e das Funções Gratificadas do Ministério do Meio Ambiente, publicado no Diário Oficial da União de 23 de Junho de 2003.

\subsection{Legislação e normas ambientais na América Latina}

A América Latina possui regiões com muitos contrastes, tanto em assuntos sociais como econômicos. Alguns lugares já atingiram um certo grau de desenvolvimento econômico e organização social comparável a certos países europeus, mas na verdade a grande parte dos países latino-americanos vivem em condições precárias. Estas desigualdades no grau de desenvolvimento econômico influenciam no modo como as sociedades pensam sobre a questão ambiental. O Brasil, o Chile, a Argentina e o Uruguai, são exemplos de países com o grau de industrialização e conscientização maior, logo possuem uma organização com as preocupações ambientais mais desenvolvidas. Um motivo que influenciou esse contexto é o grau de organização da sociedade civil, embora a maior parte desses países tenha vivido sob ditaduras que inibiam as liberdades individuais. Os investimentos e projetos realizados pelos governos ou pelas grandes empresas nacionais ou estrangeiras não levaram seus impactos ambientais com os pontos mais importantes para serem discutidos.

A partir dos anos 80, a questão ambiental passou a ser discutida com mais ênfase porque, nesse período, os problemas ambientais aumentaram, advindos da concentração populacional nas áreas urbanas, e consequentemente assuntos como acesso à agua, tratamento de esgoto, coleta de lixo e outros tornaram-se questões de grande importância para a qualidade de vida da população.

A respeito dos recursos hídricos, que são essenciais para o desenvolvimento de várias atividades econômicas e para sobrevivência de 
animais e plantas, pode-se destacar na América Latina a bacia do rio Amazonas, considerada a maior do mundo, e outras, como as bacias dos rios Paraná e Prata, situada entre a Bolívia, Paraguai, Brasil e Argentina, e o rio Orenoco, localizado entre a Venezuela e a Colômbia possuindo uma extensão de 2061 km.

O maior aqüífero do planeta está na América do Sul, o Guarani, cobrindo parte do território do Brasil, Bolívia, Paraguai, Uruguai e Argentina. O aqüífero corresponde a um manancial de água doce subterrânea. Mas, em outras regiões da América Latina, os recursos hídricos são mais escassos, demonstrando um desequilíbrio e tornando-se um grande desafio para garantir esse precioso recurso.

O México e o Peru estão entre os países com maiores problemas de escassez de água, já que utilizam aproximadamente $15 \%$ de seu estoque de recursos hídricos por ano. Grande parte dos rios brasileiros localizados em uma faixa de até $300 \mathrm{~km}$ do oceano Atlântico, onde se localizam as maiores cidades brasileiras, estão poluídos por efluentes domésticos e industriais e, parcialmente, assoreados pelas atividades agrícolas e pecuárias (Rose, 2001).

Rose cita as maiores biodiversidades pertencentes à América Latina (Rose, 2001):

- Sete dos países com maior diversidade de vertebrados do planeta;

- Doze dos países com maior diversidade de aves;

- Doze dos países no mundo com maior variedade de anfíbios;

- Cinco dos doze países no mundo com maior variedade vegetal;

- Sete dos países no mundo com mais de 70\% de seu território ainda coberto por vegetação natural.

Há aproximadamente 30 anos, a legislação ambiental não existia. Um grande fator que contribuiu para o assentamento das preocupações ambientais foi sua inserção nas constituições da grande maioria dos países. Nos últimos anos, muitos países promulgaram novas constituições e as preocupações ambientais ganharam capítulos específicos, contemplando metas de conservação, responsabilização e uso de recursos naturais.

Apresenta-se, a seguir, na TAB. 1 um resumo da Legislação e Normas Ambientais de alguns países da América Latina: 
TABELA 1 - Legislação e Normas Ambientais de Países da América Latina

\begin{tabular}{c|c|c|c|c}
\hline País & $\begin{array}{c}\text { Lei Ambiental } \\
\text { Nacional }\end{array}$ & $\begin{array}{c}\text { Ministério do } \\
\text { Meio Ambiente }\end{array}$ & $\begin{array}{c}\text { Capítulo } \\
\text { Constitucional sobre } \\
\text { Meio Ambiente }\end{array}$ & $\begin{array}{c}\text { Órgão } \\
\text { Ambiental } \\
\text { Executivo }\end{array}$ \\
\hline Brasil & 1981 & 1991 & Sim & Sim \\
\hline Chile & 1994 & 1994 & Sim & Sim \\
\hline Colômbia & 1993 & 1993 & Sim & Sim \\
\hline Equador & Em processo & 1994 & Não & Não \\
\hline México & 1988 & 1994 & Sim & Sim \\
\hline Peru & 1990 & 1995 & Não & Não \\
\hline Venezuela & 1976 & 1976 & Sim & Sim \\
\hline
\end{tabular}

Fonte: IPEA

Os problemas ambientais deixam de ser questões somente dirigidas às atividades econômicas e às ações dos governos, e passam a ser compartilhadas com a sociedade.

Foram criadas legislações específicas regulamentando assuntos como a obrigatoriedade de execução dos Estudos de Impacto Ambiental (EIA) e Relatório de Impacto Ambiental (RIMA), o adequado gerenciamento e disposição final de resíduos perigosos, as leis de crimes ambientais e normas estabelecendo padrões para emissões atmosféricas e níveis de tratamento de efluentes. Mas, muitas vezes, as legislações não contemplam sanções administrativas ou criminais.

Entre as décadas de 80 e 90, muitos países criaram entidades com preocupações ambientais na forma de ministérios, secretarias, agências, conselhos, comissões e coordenadorias. Foram através de ministérios que o México, Honduras e Nicarágua implantaram suas políticas ambientais. Já o Chile, Equador, Guatemala e Peru preferiram conduzir as questões do meio ambiente por meio de Comissões Coordenadoras.

Os países latinos de uma forma geral, já deram seus primeiros passos para a implantação de uma legislação ambiental buscando o desenvolvimento sustentável. No entanto, não é uma tarefa fácil, pois atualmente encontra-se uma fraca e não incisiva implementação da legislação que existe. Segundo Rose, temse os seguintes exemplos: extensas áreas de floresta amazônica localizada no 
Peru, no Brasil e na Colômbia, que apesar de estarem sob proteção legal, ainda são derrubadas por falta de controle das autoridades da região; no México, grande parte dos recursos hídricos está poluída por efluentes domésticos e industriais, apesar de existir legislação que exige o tratamento destas emissões; na Nicarágua, criaram-se diversas leis referentes à descarga de efluentes domésticos, industriais e agrícolas que não são respeitadas, aumentando o nível de poluição dos lagos e cursos de água; as emissões atmosféricas de atividades mineradoras na Bolívia e no Chile ainda causam danos ao meio ambiente, apesar de existirem leis regulamentando estas atividades (Rose, 2001).

Além disso, existem outros fatores que contribuem para o impedimento de uma conservação ambiental e cumprimento das legislações locais como: falta de apoio financeiro e decisões políticas para implementação de programas e projetos específicos; falta de profissionais qualificados e poucos incentivos para treinamentos.

O próprio Programa Ambiental das Nações Unidas já diz:

A legislação não é, na verdade, o fator crítico nas melhorias ambientais. A legislação não pode garantir que o intento do legislador seja implementado na prática. Os maiores problemas resultam da dificuldade de estabelecerem-se mecanismos de controle e fiscalização para a aplicação das provisões legais.

Mas existem boas perspectivas que deverão contribuir para 0 desenvolvimento do controle e legislação ambiental: a opinião pública está cada vez mais forte; os meios de comunicação estão enfatizando os problemas ambientais; as normas técnicas internacionais estão ganhando mais importância; a implantação de sistemas de gestão ambiental nas empresas está sendo muito difundida; a certificação na norma ambiental ISO 14001 está sendo mais procurada e o crescimento de Organizações Não Governamentais com atuações nas áreas ambientais está cada vez mais presente.

\subsubsection{Destaque para o Brasil na América Latina}

Entre os países da América Latina, pode-se destacar o Brasil em assuntos relacionados ao meio ambiente. O compromisso dos brasileiros com a natureza já começa com sua participação na Conferência das Nações Unidas sobre o Meio Ambiente Humano, realizada em Estocolmo em junho de 1972. 
Na década passada, mais precisamente no período de 03 a 14 de junho de 1992, o Rio de Janeiro foi sede para a Conferência das Nações Unidas sobre Meio Ambiente e Desenvolvimento, que ficou mais conhecido como ECO-92. Este evento reuniu 175 chefes de estado e de governo e teve entre seus objetivos discutir as principais alternativas para preservação, proteção e recuperação do meio ambiente terrestre. Durante o evento foi lançado a Agenda 21, que consiste em um plano de ação para ser adotado de forma global, nacional e local.

Ribeiro comenta que dez anos depois, em Johannesburgo, na África do Sul, aconteceu um reencontro, a Conferência Mundial de Desenvolvimento Sustentável, a Rio + 10, para avaliar e analisar os pontos positivos e negativos das recomendações dos planos de sustentabilidade propostos anteriormente. No intervalo das duas conferências ECO-92 e Rio + 10, ocorreu em 1997 no Japão, a assinatura do Protocolo de Quioto, em que representantes de diversos países discutiram o compromisso de reduzir a quantidade de gases poluentes. O Brasil possui um papel importante no Protocolo de Quioto: os contratos de crédito de carbono, exemplo realizado entre Biogás Energia Ambiental S.A. e o Banco Alemão KFW para venda de 1 milhão de toneladas de crédito de carbono, serão mais tarde repassados a empresas européias que emitem gases poluentes em excesso. O comércio de créditos de carbono permite que os países comprem e vendam cotas de emissão de gases poluentes. Dos 207 projetos de créditos de carbono registrados na ONU, 45 são brasileiros, liderando o ranking, seguido da Índia, México, Chile, Honduras e China, além de possuir mais 37 programas de energia limpa (Ribeiro, 2005).

A Legislação Ambiental da maioria dos países latinos não inclui sanções administrativas ou criminais, mas uma exceção importante é a Lei de Crimes Ambientais do Brasil, a Lei da Natureza, publicada em 12 de março de 1998, prevendo sanções penais pesadas para os poluidores, podendo levar até a prisão dos infratores.

Rose cita outro assunto que o Brasil se destaca: é o país na América Latina com o maior número de certificações na norma ISO 14001, com aproximadamente 450 certificações, a seguir a Argentina com de cerca de 80 certificações, o México com 45 e o Chile 25. As demais regiões estão com os números de certificações ainda reduzidas. A norma ISO 14001 é uma ferramenta para ajudar as empresas a gerenciar seus riscos ambientais como parte de suas 
práticas usuais, havendo um comprometimento com a preservação da poluição e melhorias contínuas (Rose, 2001).

\subsection{Gestão ambiental nas empresas}

Atualmente o mercado está cada vez mais aberto e competitivo, fazendo com que as empresas tenham que se preocupar com o controle dos impactos ambientais, vez que a implementação de práticas ambientais são sempre necessárias e interessantes, pois revertem em inúmeros benefícios. Os Sistemas de Gestão Ambiental (SGA) têm se tornando fortes aliados das organizações que buscam manter seus processos, aspectos e impactos ambientais sob controle.

Para Moura a decisão sobre a necessidade, ou não, de implantação de um sistema de gestão ambiental por uma empresa deve ser feita analisando se vai atender ou não a uma necessidade de seus clientes e de que forma esse sistema irá colaborar para auxiliar no cumprimento da legislação ambiental. A implantação de uma SGA é uma das melhores formas para obter melhorias de desempenho ambiental em uma empresa, cumprindo basicamente três grandes conjuntos de atividades:

- Análise da situação atual da empresa: verificar "onde estamos" no momento, no tocante ao desempenho atual da empresa, quanto aos seus produtos, serviços prestados e sistemas de produção. É a fase de diagnóstico do problema, levantando os impactos ambientais que resultam das atividades da empresa;

- Estabelecimento de metas: Estudar as possibilidades físicas, recursos materiais e humanos necessários e, a partir de diretrizes vindas da Política Ambiental, definir "onde queremos chegar" em termos de melhorias, em certo período de tempo; e

- Estabelecimento de métodos: a palavra método tem uma origem grega que significa "caminho para se alcançar a meta". Ou seja, o estabelecimento de métodos ou de um determinado modo de trabalho, vai definir "como chegar" (Moura, 2002). 


\subsection{A Contabilidade como ferramenta de gestão ambiental}

A Contabilidade tem por objetivo não só a mensuração dos fatos que evidenciam a situação patrimonial e sua evolução, mas, acima de tudo, também demonstrar, de forma clara, a todos os usuários e interessados em seus relatórios, de que modo a organização está interagindo com o ambiente em que se situa, pois informa os investimentos realizados, as despesas e as obrigações assumidas em benefício do meio ambiente, seja no sentido de evitar sua degradação ou nos gastos efetuados para recuperar agressões praticadas contra a natureza e o meio ambiente. Portanto, verifica-se que a Contabilidade Ambiental possui potencial para auxiliar os gestores no Sistema de Gestão Ambiental, porque pode ser usada para demonstrar a responsabilidade ambiental da empresa, através de relatórios contábeis que deverão evidenciar, de forma transparente e fidedigna, os gastos com o controle ambiental. 


\section{CONTABILIDADE AMBIENTAL}

O meio ambiente, atualmente, constitui-se em tema de estudo relevante e multidisciplinar, que permeia ao mesmo tempo vários campos do conhecimento. Muito tem se falado e escrito sobre o assunto. Esta discussão vem se ampliando e sendo objeto de pesquisas em áreas que até então permaneciam, aparentemente, muito distantes dessa área.

Várias ciências, como Economia, Direito, Engenharia e Administração, já estão se preocupando com a preservação ambiental, e a Contabilidade, como ciência social, apresenta condições para dar sua contribuição no assunto através da Contabilidade Ambiental.

\subsection{Surgimento da contabilidade}

A Contabilidade é uma ciência muito antiga. Evidências de registros e controle do patrimônio são datadas desde os primórdios da humanidade, aproximadamente entre 8.000 e 10.000 anos atrás. Uma das histórias representativas dessa época, segundo Silva, foi quando os pastores da Antiguidade levavam o seu rebanho para o pastoreio. De manhã, ao retirar o rebanho do cercado, os pastores colocavam uma pedra pequena em um embornal para cada ovelha que saía para o campo. Depois que todos os animais tivessem saído, tinham uma correspondência biunívoca, obtendo um conjunto de ovelhas e de pedrinhas (Silva, 1992). Slomski divide a história da Contabilidade em dois períodos: a primeira em contabilidade primitiva, e a segunda em contabilidade moderno-contemporânea (Slomski, 2005).

A contabilidade primitiva, de acordo com Slomski, era dos primórdios até o ano de 1202 da era Cristã. Os povos mais antigos, como os egípcios, já revelavam a existência de escribas e hieróglifos com significados de contagem de rebanho. A China, Confúcio (531 a 479 a.c), em sua história já possuía uma organização administrativa com atribuições de fiscalização. Na Índia, a vida antiga é retratada com códigos que referenciavam a ordem administrativa e as finanças públicas (Slomski, 2005).

Slomski cita o segundo período, a contabilidade modernocontemporânea, começando em 1202 com o livro do Abaco, de Leonardo Pisano ensinando a aritmética. No ano de 1494, o frei italiano chamado Luca Paccioli, 
condensa todos os conhecimentos contábeis, desde relatos verbais, livros e livretos que ensinavam os registros dos bens e mercadorias, e publica o livro Summa de arithmetica, geometria, proportioni e proportionalita, (Suma de aritmética, geometria, proporções e proporcionalidade) na cidade de Veneza, dessa maneira o frei italiano fica conhecido como "Pai da Contabilidade". No Brasil, a evolução da Contabilidade é recente, até a vinda de D. João VI, não havia fatos relevantes sobre o assunto. Mas no início do século passado, em 1902 foi criada a Escola de Comércio Álvares Penteado, em São Paulo. Em 1946, ocorreu a inauguração da Faculdade de Economia e Administração da Universidade de São Paulo. Posteriormente, em 1922, houve a promulgação do Código de Contabilidade da União, e 1964 foi promulgada a Lei 4.320, que estatui normas de direito financeiro para elaboração e controle dos orçamentos e balanços da União, dos Estados, dos Municípios e do Distrito Federal. Com os avanços da informática surge o SIAFI (Sistema Integrado de Administração Financeira do Governo Federal) e outros sistemas de controle. Em 4 de maio de 2000, criou-se a Lei Complementar 101, intitulada como Lei de Responsabilidade Fiscal, estabelecendo normas de finanças públicas voltadas para a responsabilidade na gestão fiscal, mediante ações em que se previnam riscos e corrijam desvios capazes de afetar o equilíbrio das contas públicas, destacandose o planejamento, o controle, a transparência e a responsabilização como premissas básicas (Slomski, 2005).

A contabilidade nasceu há milênios e vem se desenvolvendo conforme as necessidades da humanidade. Foi evoluindo e adquirindo normas até chegar à dinâmica de controle atual. Ganhou espaço no mercado de trabalho, acompanhando os avanços do contexto sócio econômico e financeiro, nas suas funções de controle e orientação da atividade contábil.

\subsection{Objetivo da Contabilidade}

Segundo Silva, o objetivo da Contabilidade é o estudo, registro e o controle do patrimônio, com a finalidade de fornecer dados à administração ou a terceiros sobre a situação econômico-financeira da entidade, seja ela com ou sem fins lucrativos (Silva, 2002). 


\subsection{Campo de atuação da Contabilidade}

O campo de atuação da ciência contábil é muito vasto porque é feito para captar, registrar, acumular, resumir e interpretar os fenômenos que afetam as situações patrimoniais, financeiras e econômicas de qualquer entidade, a qual pode ser pessoa física, pessoa jurídica com ou sem fins lucrativos, ou pessoa de direito público, como o estado, município, união, autarquia, sociedade de economia mista, empresas públicas e etc.

As informações produzidas pela área da Contabilidade são utilizadas por usuários internos e os externos.

Os usuários internos são aqueles que estão dentro da empresa, e necessitam das informações contábeis para o gerenciamento, tomada de decisões, planejamento, orçamento, rentabilidade e lucratividade, como por exemplo: gerentes, administradores, diretores, sócios e etc. É muito importante a contabilidade fornecer dados confiáveis, pois assim as decisões também serão confiáveis, uma vez que são baseadas nas informações contábeis.

Os usuários externos são aqueles que estão fora da empresa, e possuem interesses diferentes nos demonstrativos contábeis, como por exemplo: banco para aprovar empréstimos; investidores para identificar a situação financeira para investir ou não na entidade; fornecedores para averiguarem a capacidade de pagamento da empresa; governo para arrecadação de impostos; empresa pública, sociedade de economia mista e autarquias para analisarem a situação econômica, financeira da empresa para cadastro no SICAF (sistema de cadastro de fornecedores), sindicatos para acompanharem a produtividade do setor; e outros interessados como funcionários, órgãos de classe, concorrentes e etc.

Na FIG. 2 são exemplificados os usuários internos e externos da Contabilidade: 


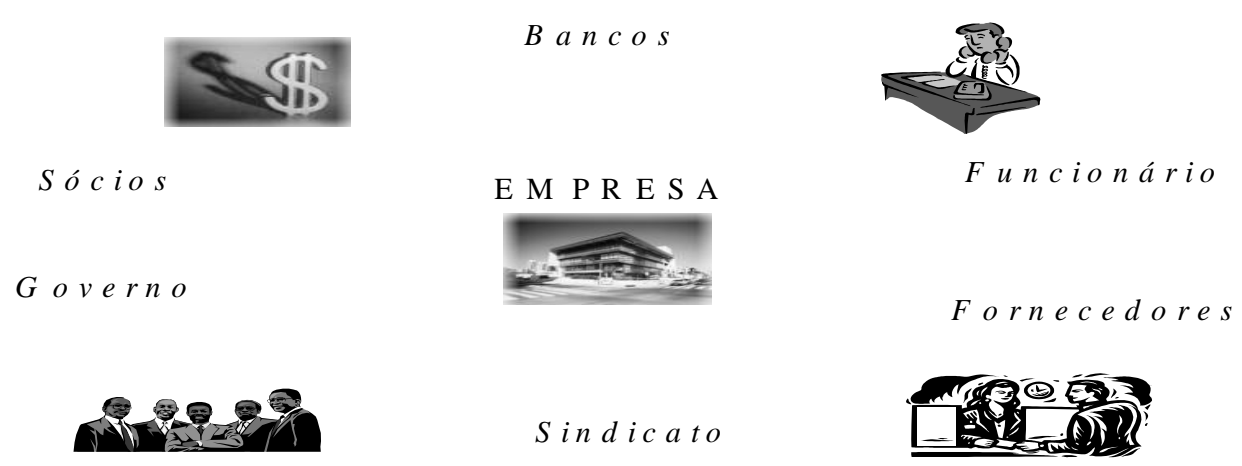

FIGURA 2 - Usuários internos e externos da Contabilidade

\subsection{Relatórios contábeis}

Relatório contábil, segundo Marion é a exposição resumida e ordenada de dados colhidos pela contabilidade. Com a finalidade de relatar às pessoas que dele se utilizam os principais fatos registrados em determinado período, também são conhecidos como informe contábeis (Marion, 2005).

Conforme a Lei das Sociedades por Ações, de 15 de dezembro de 1976, exige-se que ao final de cada exercício social, sejam elaboradas as seguintes demonstrações contábeis:

- Balanço Patrimonial;

- Demonstração do Resultado do Exercício;

- Demonstração de Lucros ou Prejuízos Acumulados ou Demonstração das Mutações do Patrimônio Líquido (a lei aceita uma das duas);

- Demonstração das Origens e Aplicações de Recursos.

De acordo com a Resolução CFC no 686 de 14 de dezembro de 1990, que aprova a NBC T.3, são definidos conceitos, conteúdo, estrutura e nomenclaturas das demonstrações contábeis em:

- Balanço Patrimonial: é a demonstração contábil que evidencia, quantitativamente e qualitativamente, numa determinada data, a situação patrimonial e financeira da entidade. Apresentando os ativos, os passivos e o patrimônio líquido. 
- Demonstração do Resultado: é a demonstração contábil que evidencia o resultado formado num certo período das operações de uma entidade, dentre o confronto das receitas, custos e despesas.

- Demonstração de Lucros ou Prejuízos Acumulados: é a demonstração contábil que evidencia, num determinado período, as mutações nos resultados acumulados de uma empresa.

- Demonstração das Mutações do Patrimônio Líquido: é a demonstração contábil que evidencia num certo período a movimentação das contas que fazem parte do patrimônio de uma empresa.

- Demonstração das Origens e Aplicações de Recursos: é a demonstração contábil que evidencia num determinado período, as modificações que originaram as variações no capital circulante líquido de uma entidade, ou seja, a folga financeira em curto prazo.

\subsection{Terminologia}

Os grandes estudiosos definem terminologias, para os conceitos contábeis como forma de orientar e facilitar o trabalho dos profissionais da área.

A seguir estão apresentadas algumas definições comumente usadas pela contabilidade geral, segundo (Martins, 1998):

- Gastos: são os sacrifícios financeiros suportados pela empresa na obtenção de produto ou serviço, sacrifícios estes representados pela entrega ou promessa de entrega de ativos. Como exemplo de gastos, temse a compra de equipamentos, de matérias-primas, pagamentos de salários e etc.

- Investimentos: são os gastos realizados com o propósito de obter benefícios futuros, tais como a aquisição de equipamentos mais modernos, treinamento de mão-de-obra, gastos com a realização de trabalhos de pesquisa e desenvolvimento de novos produtos, implantação de um novo sistema.

- Custos: são os gastos relativos à produção de um bem ou serviço, que se incorporam ao valor dos mesmos. Assim, como exemplo, ao comprar uma matéria-prima tem-se um gasto. Essa matéria-prima é um investimento enquanto está no estoque, mas vai ser transformada em custo assim que 
ela entrar no processo produtivo do bem. O produto acabado corresponde a investimento, até que seja vendido.

- Receitas: correspondem ao ingresso de elementos para o Ativo sob forma de dinheiro ou direito a receber, normalmente são as vendas de bens ou serviços.

- Despesas: são os gastos consumidos direta ou indiretamente para a obtenção da receita, como exemplo tem-se publicidade e comissão de vendedores. As despesas reduzem o patrimônio líquido da empresa, mas representam sacrifícios necessários no processo de obtenção de receitas.

- Perdas: são os bens ou serviços consumidos de forma anormal e involuntária. Elas caracterizam-se como gastos que não apresentam nenhum retorno financeiro para a empresa. Como exemplo o valor dos produtos e máquinas perdidos em um incêndio, o material obsoleto que ficou perdido em estoque e não será mais vendido, a perda ocasionada por greves.

- Lucro: é a remuneração resultante da utilização dos ativos da empresa.

- Ativo: são todos os bens e direitos de propriedade da empresa.

- Passivo: são todas as obrigações da empresa.

- Patrimônio: conjunto de bens, direitos e obrigações.

\subsection{Contabilidade Ambiental}

A contabilidade é uma grande ferramenta para a tomada de decisões através de seus relatórios, principalmente o Balanço Patrimonial e a Demonstração de Resultado.

Segundo Silva, a preocupação ecológica da sociedade tem afetado o ambiente empresarial, e ganhado destaque por causa da sua relevância na relação na qualidade de vida das pessoas. Em resposta a essa movimentação ecológica, determinadas organizações se antecipam à situação criando uma nova função administrativa em suas estruturas com a responsabilidade de cuidar das atividades empresariais relacionadas com o meio ambiente. A criação da nova função administrativa e o surgimento dessa variável ecológica no meio empresarial afeta o patrimônio ambiental da empresa e o patrimônio ambiental público, que são objeto de estudo da Contabilidade Ambiental (Silva, 2003). 
Com sua forma sistemática a área contábil colabora para a proteção do meio ambiente, contabilizando as operações relacionadas com impactos negativos ou positivos causados na natureza, através de uma vertente conhecida como Contabilidade Ambiental, surgida nos meados da década de 70.

Para Tinoco \& Kraemer a contabilidade do meio ambiente passou a ter status de um novo ramo da ciência contábil em fevereiro de 1998, com a finalização do "relatório financeiro e contábil sobre passivo e custos ambientais", realizado pelo grupo de trabalho, intergoverntamental das Nações Unidas de Especialistas em padrões Internacionais de Contabilidade e relatórios (ISAR United Nations Intergovernmental Working Group of Experts on International Standards of Accounting and Reporting) (Tinoco \& Kraemer, 2004).

A Contabilidade Ambiental é um dos ramos da Contabilidade Geral, como a Contabilidade Pública, Contabilidade Financeira, Contabilidade de Custos, Contabilidade Bancária e outras (FIG. 3), e a qual deve ser aplicada de acordo com a dependência e relação do ramo de atividade ou operação.
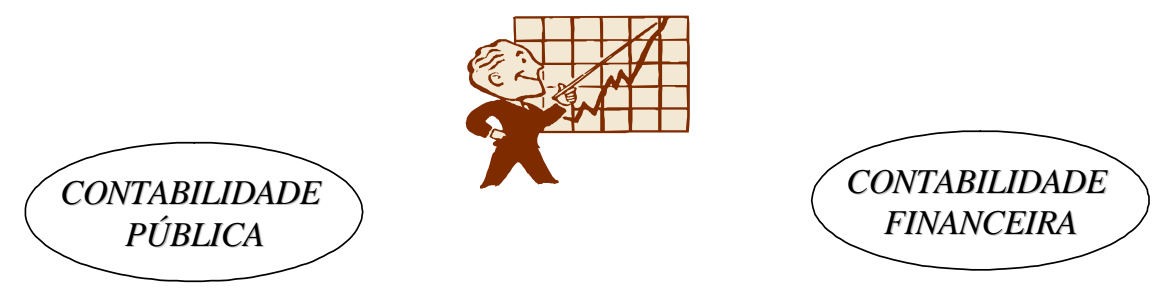

\section{CONTABILIDADE GERAL}
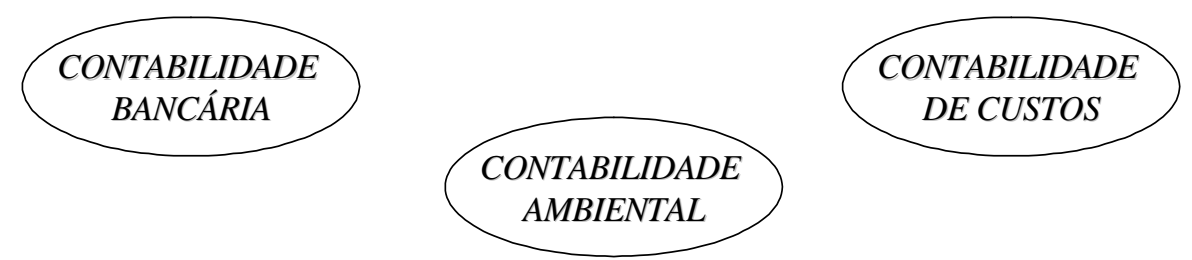

FIGURA 3 - Ramos da Contabilidade 
A Contabilidade Ambiental se preocupa com o meio ambiente, desenvolve e estuda maneiras de identificar os gastos ambientais apropriados aos produtos e serviços, assim podendo demonstrar o patrimônio ambiental da entidade.

A Norma e Procedimento de Auditoria (NPA) $n^{\circ} 11$ do IBRANCON define ativos e passivos ambientais:

- Ativo ambiental: de um modo geral os componentes dos ativos ambientais são o Imobilizado, relacionado aos equipamentos comprados para eliminação ou redução de agentes poluentes; o gasto com pesquisas e desenvolvimento de tecnologias a médio e longo prazo; estoques quando se referem a insumos do processo de eliminação dos níveis de poluição. Pertencem a este item, também, os impostos, obras de infra-estrutura local, escolas, creches, áreas verdes e ajardinadas. Buscando o desenvolvimento e a valorização da região e eliminando o passivo ambiental, a empresa gera ativo.

- Passivo ambiental: pode ser conceituado como toda agressão que se praticou ou que se pratica contra o meio ambiente e refere-se aos valores dos investimentos necessários para reabilitá-lo, bem como multas e indenizações em potencial.

\subsection{Interação com o meio ambiente}

As organizações ao captarem do meio ambiente recursos naturais não renováveis (aqueles que se encontram na natureza em quantidades limitadas e se extinguem com a sua utilização; uma vez esgotada, as reservas não podem ser regeneradas, como o carvão, petróleo, gás natural e o urânio), ou renováveis (aqueles que depois de utilizado ainda pode-se dispor para utilização, como a energia solar e eólica), estarão utilizando o patrimônio da humanidade. Quando não consumidos totalmente e devolvidos de forma deteriorada, eles afetam negativamente o patrimônio natural pela redução do volume de água potável, do nível de qualidade do ar e da área de terras habitáveis ou cultiváveis, o que restringe, a longo prazo, as condições de vida das gerações futuras, e até mesmo da presente. Dessa forma, contribuem para a sua extinção quando o consumo de tais recursos é total e indiscriminado. 
Essas preocupações podem ser resumidas no conceito de Desenvolvimento Sustentável, apresentado no relatório de Brundtland (1987), o qual preconiza que devemos nos preocupar em satisfazer as necessidades presentes sem comprometer a capacidade das gerações futuras de suprirem suas próprias necessidades.

Para Ribeiro as empresas são cada vez mais pressionadas, por vários segmentos, para melhorar e aperfeiçoar seus processos produtivos a fim de reduzir as agressões ao meio ambiente. Essas pressões se refletem em fatos e atitudes, como os relacionados a seguir:

- As legislações que, mundialmente tratam da obrigatoriedade de acondicionamento dos resíduos tóxicos, são novas ainda e objetivam a redução das agressões ambientais. Sua implementação consome importante soma de recursos e tecnologias avançadas e caras;

- Os produtos biodegradáveis requerem estudo e desenvolvimento de tecnologias não agressivas à natureza, que resultam na substituição de elementos do processo produtivo e na redução do teor tóxico das águas residuais desse processo;

- As exigências quanto ao tratamento dos resíduos tóxicos, antes do seu lançamento ao meio ambiente, têm resultado no desenvolvimento e aquisição de tecnologias caríssimas e, em alguns casos, na reutilização daqueles que são tratados no próprio processo produtivo, como no caso das águas residuais que recebem tratamento e são utilizadas para gerar energia interna;

- O EIA e o RIMA são documentos amplamente utilizados em todo o mundo. A autorização para que uma empresa funcione, em determinado setores econômicos, está condicionada à sua apresentação aos órgãos técnicos responsáveis (Ribeiro, 2005).

Donaire defende que empresas têm demonstrado que é possível ganhar dinheiro e proteger o meio ambiente mesmo não sendo uma organização que atua no chamado "mercado verde", desde que possuam certa dose de criatividade e suas condições internas possam transformar as restrições e ameaças ambientais em oportunidade de negócios (Donaire, 1999). 


\subsection{Balanço Social}

A sociedade precisa da empresa, porém essa precisa mais da sociedade, pois sem o seu aval nenhuma empresa permanece no mercado por muito tempo. Para Ribeiro \& Lisboa, o Balanço Social é um conjunto de informações da empresa para a sociedade, por meio do qual a justificativa para sua existência deve ser explicitada. Esta justificativa deve provar que o seu custobenefício é positivo, porque agrega valor à economia e à sociedade, pois respeita os direitos humanos e de seus colaboradores e, ainda, porque desenvolve todo o seu processo operacional sem agredir ao meio ambiente (Ribeiro \& Lisboa,1999).

Para Silva o Balanço Social é um instrumento colocado na mão de empresários para que possam mensurar e refletir como está a empresa, no seu campo social. Trata-se de uma avaliação para julgar os fatos sociais relacionados à entidade, tanto sua relação interna com os empregados, como externamente com a comunidade (Silva, 2003).

De acordo com Silva, a idéia do Balanço Social começou a ser difundida no começo dos anos 70. Na França em 1977, foi aprovada a lei que obrigava a elaboração desse instrumento de informação social, sendo, a princípio somente para fornecer informações sobre os recursos humanos, mas com a evolução do conceito de responsabilidade social, a difusão do conceito de valor adicionado, o Balanço Social passou a abordar também evidenciações do quanto a empresa estava adicionando à economia do ambiente social onde está inserida. Com a disseminação do conceito de desenvolvimento sustentável, das normas de certificação da qualidade ambiental, ele passou a abordar também aspectos sociais voltados à preservação e à conservação do meio ambiente (Silva, 2003).

No Brasil, a proposta só ganhou impulso nacional quando o sociólogo Herbert de Souza, o Betinho, em junho de 1997, lançou uma campanha pela divulgação voluntária do Balanço Social. Com o apoio e a participação de lideranças empresariais a campanha decolou e vem ganhando uma série de debates através da imprensa.

Um dos pontos mais polêmicos do Balanço Social é a questão da obrigatoriedade. Uns consideram que é necessário impor a publicação desse tipo de balanço, outros acham que deveriam ser pela escolha das empresas. Mas Ribeiro diz que independente da obrigatoriedade, por questão de responsabilidade social, a empresa que sempre buscou o lucro, precisa também 
incluir entre suas metas a satisfação da sociedade. Por sociedade entende-se investidores, clientes, governo, empregados, fornecedores e a população em geral. E por satisfação entende-se não apenas a qualidade do produto, como também a do meio ambiente antes, durante e depois do processo produtivo, a segurança e as condições no ambiente de trabalho, além de quantidade e preços adequados, ou seja, todo o ciclo de vida do produto ou serviço (Ribeiro, 2005).

Segundo Silva, este é o principal causador de inúmeras discussões, tanto nos meios acadêmicos, pesquisadores da área, como em órgãos regulamentadores e de apoio à profissão contábil. Ele insere uma observação quanto à obrigatoriedade ou não da contabilidade ambiental, porque na maioria dos países não existe legislação obrigando a divulgação de dados relativos ao meio ambiente. A atenção fornecida pelas empresas é um fator de competitividade, assim a aplicação da contabilidade ambiental pode e deve ocorrer independentemente da existência de uma legislação prévia tornando-a obrigatória. Nenhuma vantagem competitiva até hoje foi imposta como algo obrigatório para as empresas (Silva, 2003).

O Balanço Social envolve informações de natureza social, evidenciando as seguintes vertentes:

- Valor Adicionado;

- Recursos Humanos;

- Meio Ambiente;

- Benefícios a Comunidade.

A seguir, a FIG. 4 mostra as vertentes do Balanço Social:

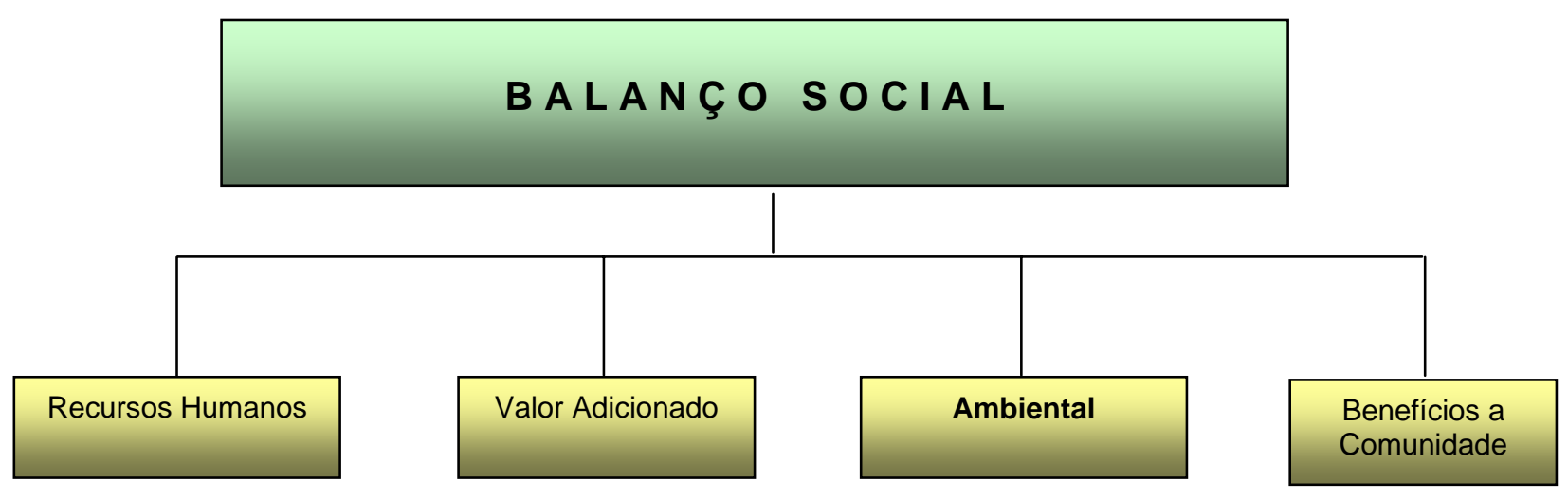

FIGURA 4 - Vertentes do Balanço Social Fonte: Silva, 2003 
A vertente dos Recursos Humanos, segundo Pinto \& Ribeiro, procura evidenciar o perfil da força de trabalho: sexo, idade, formação escolar, estado civil, tempo de trabalho na empresa, remuneração, benefícios concedidos, e gastos com treinamento dos funcionários (Pinto \& Ribeiro, 2005).

Segundo De Luca, a vertente Demonstração do Valor Adicionado (DVA) é um conjunto de informações de natureza econômica. É um relatório contábil que procura demonstrar o valor da riqueza gerada pela empresa e a distribuição para os diversos setores que contribuíram direta ou indiretamente para sua geração. A DVA é parte integrante do Balanço Social e não uma demonstração isolada como muitas empresas divulgam. Ela não contradiz a tradicional demonstração do resultado do exercício. Trata-se de uma visão diferente em termos de demonstrações contábeis. A demonstração do resultado do exercício está mais voltada a determinado tipo de usuário (proprietário, sócio ou acionista) que quer conhecer o resultado líquido da empresa em determinado período, bem como avalia a parte da riqueza criada pela empresa que se destina ao proprietário (detentor de cotas ou ações). Importantes informações sobre a atividade empresarial podem ser extraídas, tais como: valor adicionado da atividade produtiva, valor adicionado total dos negócios, parcela do valor adicionado distribuída aos empregados, ao Governo, aos acionistas e aos terceiros, além de valores retidos na empresa (De Luca, 1998).

Benefícios a Comunidade, segundo Pinto \& Ribeiro, podem refletir o grau de responsabilidade social e o comprometimento da empresa com as necessidades básicas da população, mediante investimentos voluntários nas diferentes áreas. Têm por objetivo demonstrar o que a empresa faz em termos de benefícios sociais, tais como contribuições a entidades assistenciais, filantrópicas, preservação de bens culturais e educação de necessitados (Pinto \& Ribeiro, 2005).

Em relação à questão ambiental o Balanço Social, que melhor pode ser exposto através do seu componente o Balanço Ambiental, mostra a preocupação da entidade com o meio ambiente, com a natureza e seus recursos, com os gastos para preservação, proteção, recuperação e conservação dos recursos, e todos os investimentos, incentivos e educação para a área ambiental.

A seguir na TAB. 2 é apresentado um quadro resumo das informações fornecidas por diversas empresas relativas aos gastos com o meio ambiente. 
TABELA 2 - Informações sobre gastos com o meio ambiente

\begin{tabular}{l|l}
\hline Empresa & \multicolumn{1}{c}{ Informação } \\
\hline Teka S/A & $\begin{array}{l}\text { Desde 1978, investiu mais de } 6 \text { milhões de dólares na implantação de } \\
\text { estações de tratamento de efluentes líquidos e gasosos. }\end{array}$ \\
\hline Karsten S/A & $\begin{array}{l}\text { Ações empreendidas como reutilização da água; controle de emissões } \\
\text { atmosféricas; e campanha de redução de energia. }\end{array}$ \\
\hline Cremer S/A & $\begin{array}{l}\text { Ações de preservação do meio ambiente; possui moderno sistema de } \\
\text { tratamento de efluentes com capacidade de 150m } \\
\text { mantém em funcionamento três lavadores de gases com a finalidade de } \\
\text { despoluição dos gases lançados à atmosfera. }\end{array}$ \\
\hline Frigorífico Aurora & $\begin{array}{l}\text { Educação ambiental e programa reciclagem vida implantado em 1994. As } \\
\text { idéias básicas são reaproveitar e dar o destino adequado aos materiais } \\
\text { recicláveis como metal, papel e plástico. }\end{array}$ \\
\hline Perdigão S/A & $\begin{array}{l}\text { Execução de projetos e programas como: sistema de tratamento de efluentes } \\
\text { e gases; processamento de resíduos sólidos; reflorestamento; preservação e } \\
\text { conservação de rios; redução do consumo de energia e água; educação } \\
\text { ambiental; e suporte aos seus produtores integrados na questão ambiental. }\end{array}$ \\
\hline Sadia S/A & $\begin{array}{l}\text { Desenvolve programas de reciclagem de material orgânico, utilizado na } \\
\text { adubação de lavouras dos produtores integrados e de materiais inorgânicos. }\end{array}$ \\
\hline Tupy S/A & Em 2001, investiu 9 milhões na defesa do meio ambiente. \\
\hline
\end{tabular}

Fonte: Revista Brasileira de Contabilidade, Julho/Agosto 2005, nº 154, páginas 45 e 46

\subsection{Valoração econômica ambiental}

A valoração econômica ambiental é um conjunto de técnicas que procuram avaliar monetariamente o recurso ambiental, em relação a outro existente na economia.

As técnicas de valoração econômica ambiental buscam mensurar as preferências das pessoas por um recurso ou serviço ambiental e, portanto, o que está recebendo "valor" não é o meio ambiente ou o recurso ambiental, mas as preferências das pessoas em relação a mudanças de qualidade ou quantidade ofertada do recurso ambiental. Essas preferências em relação a mudanças na qualidade ou quantidade desses recursos são traduzidas em medidas de bemestar, que podem ser interpretadas como a Disposição a Pagar (DAP) de um indivíduo por uma melhoria ou incremento no recurso ambiental ou como a Disposição a Aceitar (DAA) uma piora ou decréscimo na oferta do recurso (May et al, 2003).

O valor econômico dos recursos ambientais normalmente não é observado no mercado por intermédio do sistema de preços. No entanto, como os 
demais serviços presentes no mercado, seu valor econômico deriva de seus atributos, com a peculiaridade de que estes atributos podem ou não estar associados a um uso (Motta, 2006).

Conforme Oliveira \& Maciel, a importância da valoração econômica ambiental é estimar os custos sociais de usar recursos ambientais escassos ou incorporar os benefícios sociais advindos do uso desses recursos, ou seja, é a análise de custo/benefício de recursos ambientais. Com isso, a valoração econômica ambiental se torna uma ferramenta para a gestão dos recursos e tomada de decisões que participem projetos com impacto ambiental, possibilitando incluir o meio ambiente nas estratégias de desenvolvimento econômico (Oliveira \& Maciel, 2008).

\subsubsection{Métodos de valoração econômica ambiental}

Conforme Philippi Jr, se aos recursos naturais, antes vistos como bens livres e agora reconhecidos como recursos naturais escassos, forem atribuídos preços capazes de refletir sua efetiva escassez, sua preservação será mais provável. Mas é muito difícil atribuir preços ao ar, à água, ao solo, ao ecossistema, à biodiversidade, à flora e à fauna. São grandes os riscos de atribuir valores a esses bens, a tarefa é complexa e requer que se arbitre no presente e com dados imprecisos e incompletos, o interesse dos futuros habitantes do planeta (Philippi Jr et al, 2004),.

Os métodos de valoração econômica ambiental são classificados de diversas maneiras por vários autores, possuindo suas vantagens e desvantagens, cada uma com sua peculiaridade. A seguir destacam-se os mais usuais:

- Custo de viagem: estima o valor de uso recreativo por meio de análise dos gastos incorridos pelos visitantes desse lugar. Normalmente usam-se questionários aplicados em uma amostra de visitantes do lugar de recreação para levantar dados como: o lugar de origem das pessoas, seus hábitos e gastos relacionados à viagem. Desses dados podem-se calcular custos de viagem e relacioná-los a uma freqüência de visitas, de modo que uma relação de demanda seja estabelecida. Essa função de demanda por visitas ao lugar de recreação é, então, usada para estimar o valor de uso desse lugar (May et al, 2003). 
- Preços hedônicos: estima os custos sociais através de preços implícitos de certas características no valor de propriedade. Compara-se os preços de imóveis situados em áreas atingidas por poluição com outros semelhantes em outras áreas, a diferença dos preços seria o valor que se atribui à poluição do ar (Philippi Jr et al, 2004).

- Custo de reposição: técnica onde são feitas estimativas dos custos que seriam necessários para repor o ativo danificado. Não se trata de uma medida do benefício de se evitar o dano, uma vez que esta técnica é mais bem aplicada quando existe a certeza de que o dano vai acontecer ou aconteceu (Philippi Jr et al, 2004).

- Custos evitados: quando o custo de um produto substituto representa os gastos incorridos pelo consumidor para não alterar o produto que depende do recurso ambiental. Por exemplo, gastos com aquisição de produtos químicos para tratamento de água quando existem despejos de esgotos em curso d'água usado para abastecimento (Motta, 2006).

- Custos de controle: quando o dano ambiental pode ser valorado pelos custos de controle em que empresas ou consumidores incorrem para evitar a perda de qualidade do recurso ambiental. Por exemplo, gastos com disposição adequada de lixo industrial para evitar a degradação dos corpos hídricos (Motta, 2006).

- Produtividade marginal: se o recurso é um insumo de um bem ou serviço, este método utiliza-se de preços de mercado deste bem ou serviço para estimar o valor econômico do recurso ambiental (Motta, 2006).

- Custo de oportunidade: esse método não valora diretamente o recurso ambiental. Pelo contrário, estima o custo de preservá-lo pela não realização de uma atividade econômica concorrente. Ou seja, é o custo de oportunidade da renda sacrificada em prol da preservação do recurso ambiental (Motta, 2006).

- Valoração contingente: consiste na utilização de pesquisas amostrais para identificar monetariamente, as preferências individuais em relação a bens que não são comercializados em mercados. Pergunta-se o quanto as pessoas avaliam situações hipotéticas envolvendo uma mudança na qualidade ou quantidade de um recurso ambiental (May et al, 2003). 


\subsubsection{Externalidades e interiorização dos custos ambientais}

O conceito de externalidade, para Philippi Jr et al, aparece quando uma empresa adiciona para outra sem o desejar, custos ou benefícios, independentemente de transações mercadológicas, e seus efeitos podem ser tanto positivos, como negativos (Philippi Jr et al, 2004).

A construção de empresa em num determinado local podem produzir externalidade positiva como a criação de infra-estrutura mais adequada para a comunidade, e externalidade negativa como a poluição do ar, por exemplo. Moura cita que a solução preconizada é que essas externalidades negativas sejam internalizadas, ou seja, identificados os custos decorrentes do empreendimento e, estes custos sejam imputados ao projeto (Moura, 2003). 


\section{INSTITUIÇÃO}

\subsection{Coordenadoria para Projetos}

De acordo com a ordem interna 01/2006 do Centro Tecnológico da Marinha em São Paulo (CTMSP), a idéia da implementação de um órgão que reunisse os esforços em prol do desenvolvimento da Ciência \& Tecnologia no Brasil foi, possivelmente, concebido em 1946 durante a $1^{\text {a }}$ reunião da Comissão de Energia Atômica da ONU, quando foi apresentado o "Plano Baruch". Pretendia-se que as "injustiças" em relação à distribuição de reservas de minérios radioativos pelo mundo fossem corrigidas através da cessão desses minérios aos países detentores da tecnologia nuclear. O Almirante Álvaro Alberto foi o representante brasileiro nesse encontro, e sua posição era a de que nossos minérios poderiam ser exportados, mas a preço justo e em troca de fornecimento de equipamentos, assistência técnica e transferência de tecnologia na área nuclear. Tese que foi aceita internamente se tornando conhecido como a "Lei das Compensações Específicas". Além disso, foi também por ele proposta a criação de um organismo de coordenação e direção das atividades científicas e especificamente nucleares, o que ocorreu em 15 de janeiro de 1951 com a criação do CNPq. Entre os principais desejos do Almirante Álvaro Alberto estavam à construção de uma usina para produção de Hexafluoreto de Urânio e a fabricação de Reatores de Pesquisa e Potência.

Aos 17 dias do mês de outubro de 1986 foi criada a Coordenadoria para Projetos Especiais (COPESP), através do decreto $n^{\circ}$ 93.439, ocorrendo um rápido desenvolvimento dos trabalhos, culminando com a inauguração do Centro Experimental Aramar (CEA) em 1988, a fim de viabilizar a construção de um Reator Nuclear de pequena potência e dominar todas as etapas do ciclo do combustível.

Em 11 de setembro de 1995, a denominação foi alterada para Centro Tecnológico da Marinha em São Paulo. O CTMSP está situado à Av. Prof. Lineu Prestes, 2468, na Cidade Universitária, no município de São Paulo. Uma vista aérea do CTMSP é apresentada na FIG. 5, a seguir. 


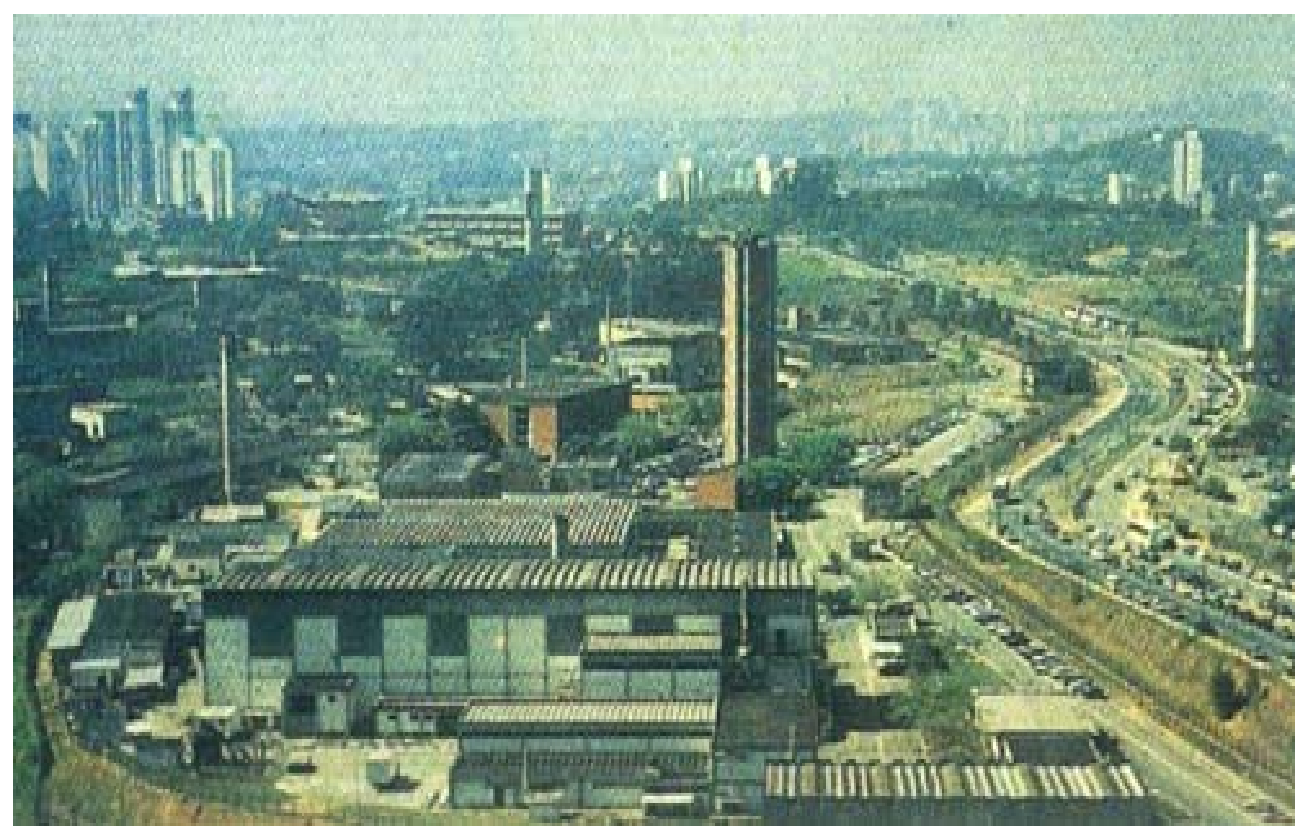

FIGURA 5 - Vista aérea do CTMSP no campus do IPEN Fonte: www.agencia.fapesp.br

\subsection{O Centro Tecnológico da Marinha em São Paulo}

O CTMSP é uma organização militar (OM) que trabalha em pesquisa e desenvolvimento de sistemas nucleares e energéticos para serem aplicados na propulsão de navios, com o intuito de preservar os interesses marítimos do Brasil. Ele está subordinado à Diretoria-Geral do Material da Marinha (DGMM), e esta ao Comando da Marinha (CM) que junto ao Comando do Exército mais o Comando da Aeronáutica, compõem o Ministério da Defesa.

A OM atua em diversas áreas tecnológicas como o desenvolvimento de sistemas térmicos, químicos e eletro-mecânicos, de processos químicos e projetos, fabricação e testes de componentes, contando com diversas instalações laboratoriais, oficinas, usinas e protótipos. Um resumo de suas principais atividades é mostrado na FIG. 6: 


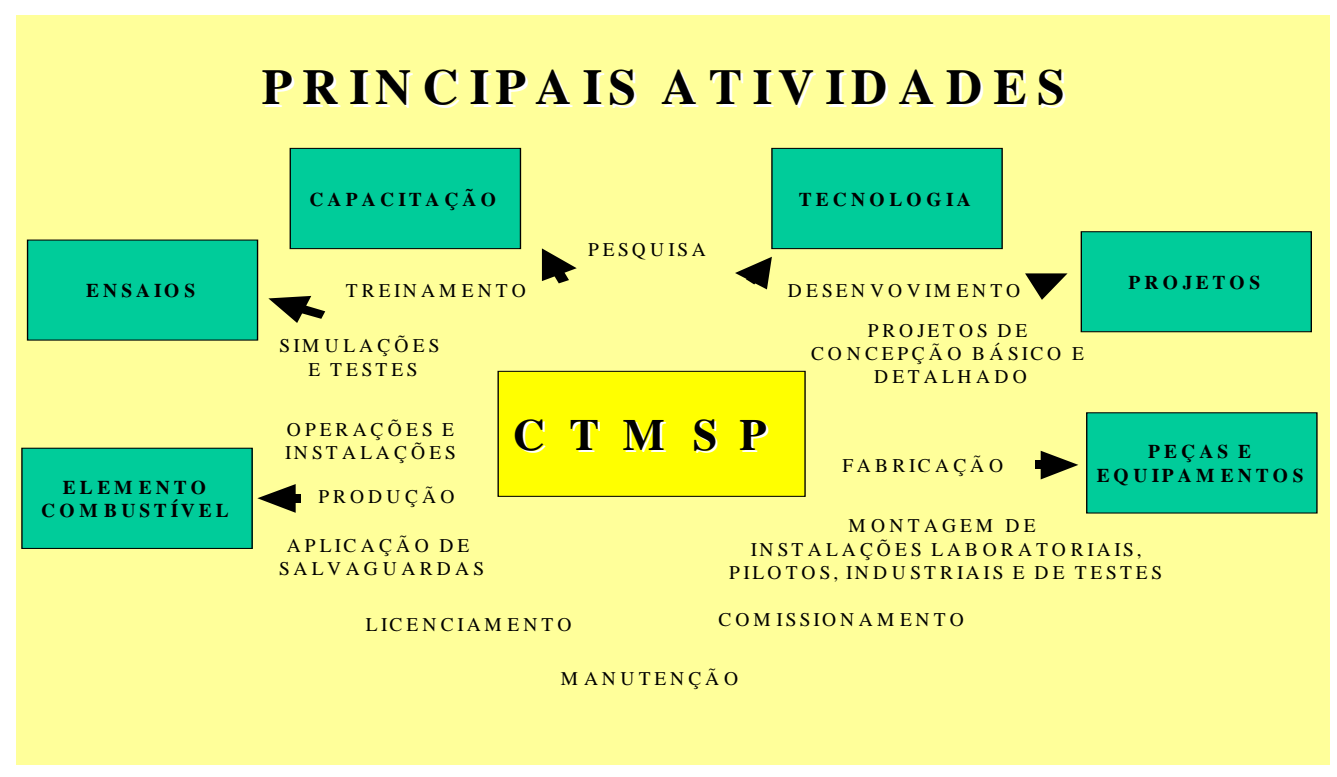

FIGURA 6 - Principais atividades do CTMSP

Fonte: CTMSP

No CTMSP existem superintendências que dão apoio aos desenvolvimentos em andamento, e coordenadorias que gerenciam as atividades dos projetos. Na FIG. 7 é apresentada a estrutura da instituição conforme seu organograma atual:

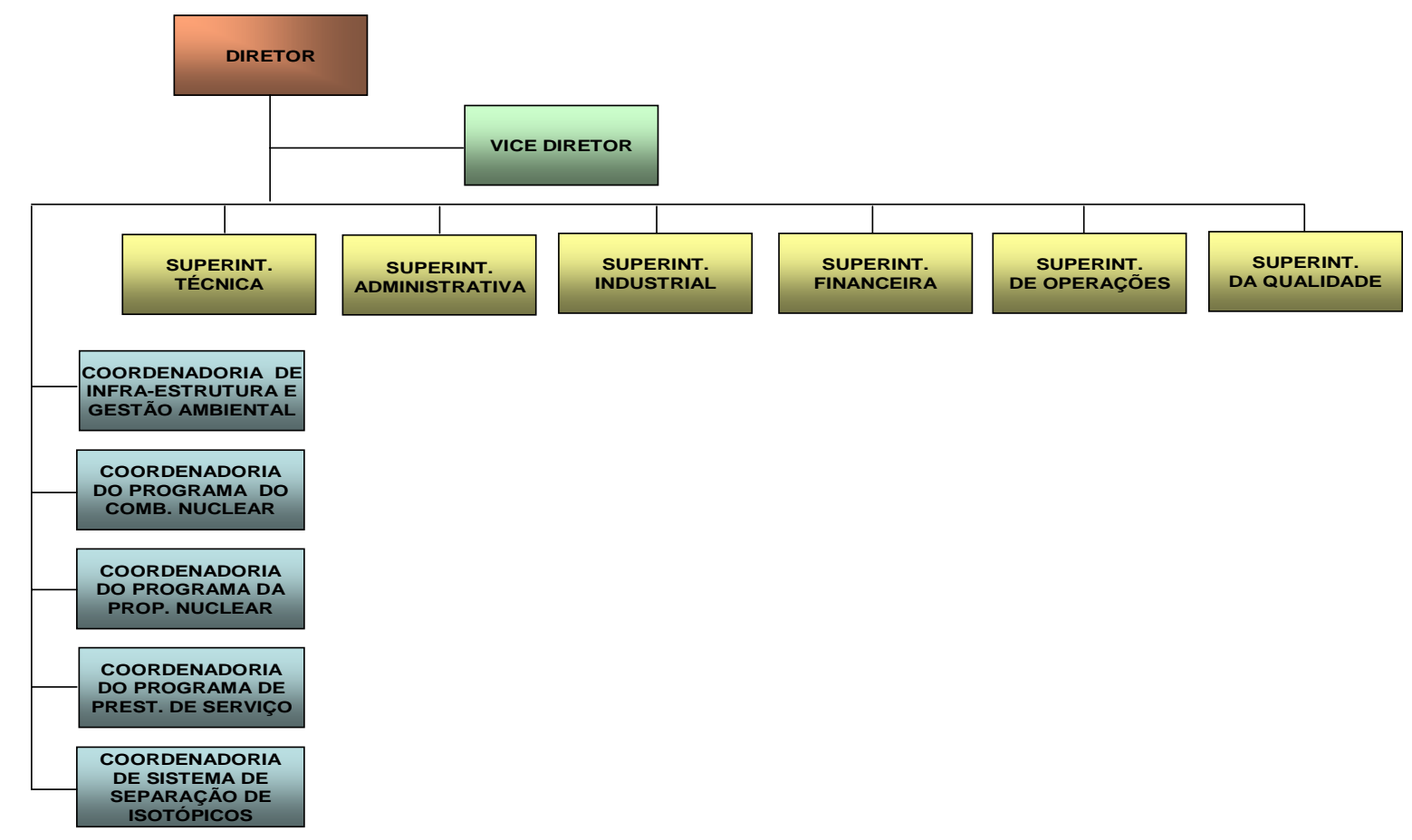

FIGURA 7 - Organograma geral CTMSP

Fonte: CTMSP 


\subsection{Centro Experimental Aramar}

O Centro Experimental Aramar (CEA) é parte integrante do CTMSP e está situado na cidade de Iperó, em área pertencente à Fazenda Ipanema, interior do estado de São Paulo, a aproximadamente $100 \mathrm{~km}$ da capital paulista. Contempla duas áreas de trabalho bem definidas: o ciclo do combustível nuclear e a propulsão nuclear. A instalação do CEA foi definida após estudos de diversos lugares, considerando a facilidade de locomoção do pessoal técnico-gerencial. Além disso, a escolha levou em consideração a topografia, climatologia, geologia, sismologia, hidrologia, energia elétrica, transporte, água e facilidade para aquisição. No que se refere à aquisição, esse fator foi decisivo, porque a área já pertencia ao Governo significando, na época, custo zero para adquirir o terreno.

O CEA, como o próprio nome diz, é um centro experimental e suas instalações são de pequeno porte. As atividades de concepção são efetuadas no CTMSP sede, e no CEA são realizadas as atividades experimentais, contando com oficinas especializadas, laboratórios e bancadas de testes, unidades pilotos de demonstração industrial do ciclo do combustível nuclear e infra-estrutura de apoio para as instalações. Uma vista aérea do CEA é mostrada na FIG. 8.

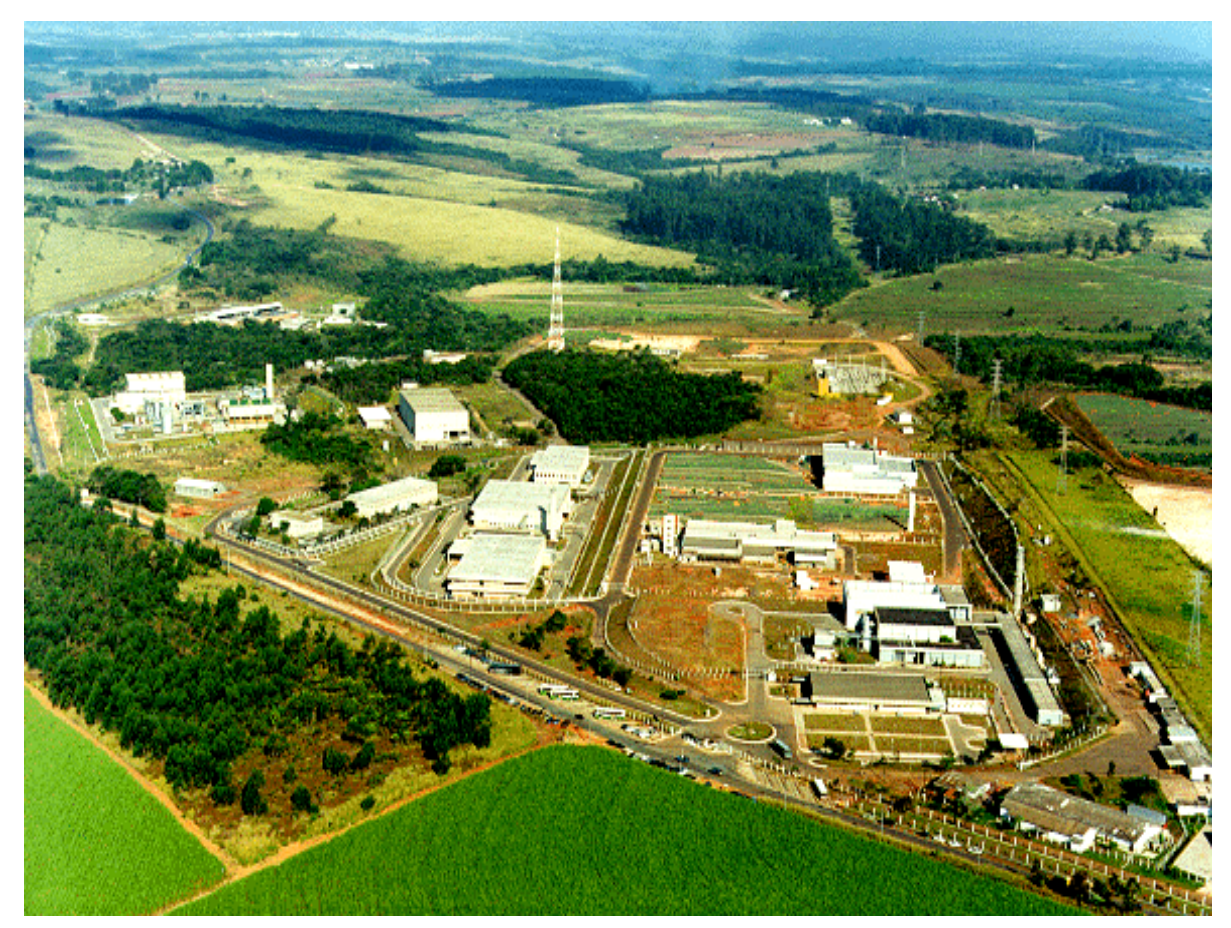

FIGURA 8 - Vista aérea do Centro Experimental Aramar 


\subsection{Unidade de Produção de Hexafluoreto de Urânio}

No Centro Experimental Aramar encontra-se a Unidade de Produção de Hexafluoreto de Urânio, a USEXA. Segundo Izique, as obras civis estão concluídas e pelo menos $75 \%$ dos equipamentos já estão comprados e entregues, faltando a montagem eletromecânica e os sistemas de controle. A conclusão do projeto ainda demanda gastos, mas parte dos recursos já foi obtida junto ao Fundo Setorial de Energia, administrado pela Financiadora de Estudos e Projetos (FINEP) (Izique, 2004).

No ciclo do combustível nuclear, o custo da etapa de produção do hexafluoreto de urânio representa aproximadamente 8\%. O maior custo é a etapa de enriquecimento realizado por meio de tecnologia de ultracentrifugação. De qualquer maneira, o domínio dessa tecnologia é estratégico, uma vez que as usinas nucleares tipo PWR necessitam de urânio enriquecido em ${ }^{235} \mathrm{U}$ e o processo de ultracentrifugação requer urânio sob a forma gasosa. O único produto de urânio estável sob a forma gasosa, em condições razoáveis de temperatura e pressão é o UF $_{6}$ (hexafluoreto de urânio). Na FIG. 9 é mostrada a vista aérea da USEXA:

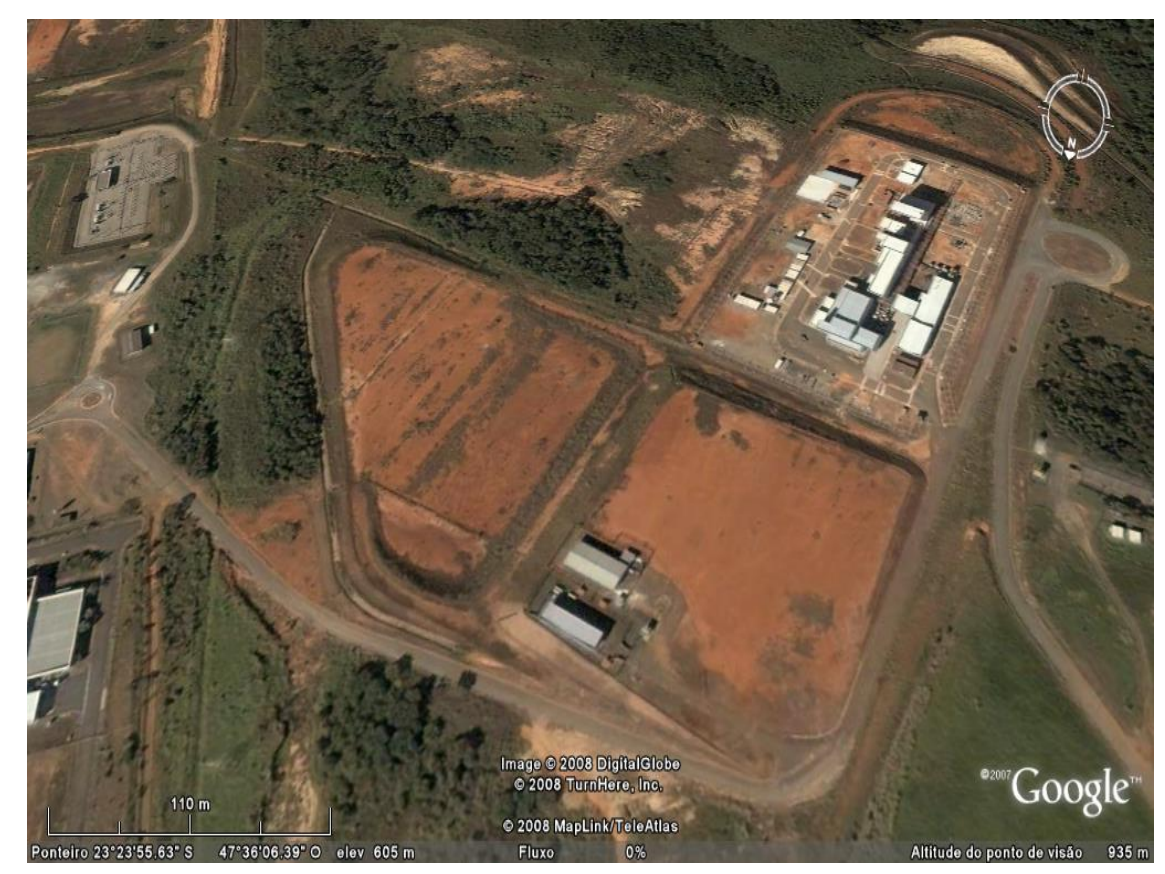

FIGURA 9 - Vista aérea da USEXA

Fonte: Google Earth 


\section{ENERGIA NUCLEAR}

\subsection{Histórico}

Uma seqüência de pesquisas em física atômica e nuclear no período de 1879 e 1939 levou a descoberta da fissão. Desenvolveu-se uma nova ciência sobre partículas e raios, radioatividade, equivalência entre matéria e energia, transmutação nuclear e a estrutura do átomo e do núcleo. A existência da fissão sugeriu que uma reação em cadeia envolvendo nêutrons era possível e que o processo teria grandes perspectivas na geração de energia (Murray, 2004).

Segundo Hammond et al, o primeiro uso da energia nuclear pelo homem foi destinado para a produção de armamentos. O projeto Manhattam que conduziu ao desenvolvimento da bomba atômica durante a Segunda Guerra Mundial levou também ao desenvolvimento de vários reatores nucleares para fabricar plutônio. Mesmo durante a guerra a probabilidade de que tais reatores pudessem ser uma nova e potente fonte de energia já havia sido prevista. A esperança que a energia nuclear pudesse provar o benefício da utilização atômica pacífica conduziu, no final dos anos 40, a um programa de pesquisa sob a égide da Comissão de Energia Atômica. A despeito do otimismo dos primeiros proponentes, foram consumidos muitos anos de esforços e grandes quantias de dinheiro para desenvolver, primeiramente, pequenas plantas para submarinos nucleares e, mais tarde, grandes reatores de potência (Hammond et al, 1973).

\subsection{Energia nuclear}

As diferentes formas de geração de energia elétrica têm suas vantagens e desvantagens. Assim como o carvão tem baixo custo, mas necessita de muitos gastos para controle do ar, as hidroelétricas têm baixo custo operacional, mas afetam o meio ambiente com a inundação de grandes áreas. A energia nuclear também possui os dois lados:

- Vantagens: é a fonte mais concentrada de geração de energia, base científica extensiva para todo ciclo, transporte seguro como novo combustível e não provoca a chuva ácida, sendo considerada uma energia limpa.

- Desvantagens: fonte de maior custo por causa dos sistemas de emergência, de contenção, de tratamento de resíduo radioativo e do seu 
armazenamento, que requer uma solução em longo prazo para os resíduos de alta atividade armazenados e potencial proliferação nuclear bélica.

Outra vantagem citada por Dantas é que os rejeitos radioativos frente aos outros rejeitos produzidos pela humanidade têm provocado um impacto insignificante ao ambiente, devido a fatores como volume menor, o que facilita o tratamento, e liberação controlada na biosfera. Com isso é possível identificar onde estão armazenados todos os rejeitos radioativos que já foram produzidos (Dantas, 2007). Para exemplificar como essas duas características, volume e concentração, são vantajosos, o atual presidente da INB, Alfredo Tranjan, comparou a produção de rejeitos das diferentes fontes de geração térmica. Ele tomou como base as usinas movidas a carvão, a óleo, a gás natural e uma usina nuclear, todas do mesmo porte, com uma geração hipotética de $1 \mathrm{MW}$ elétrico ao longo de um ano (Dantas, 2007). Na TAB. 3 é demonstrada a comparação da produção de rejeitos de diferentes fontes de energia.

TABELA 3 - Comparação da produção de rejeitos de diferentes fontes de energia

\begin{tabular}{l|c|c}
\hline Tipo de Térmica & $\begin{array}{c}\text { Consumo de combustível } \\
\text { para produção de 1 MW e ao } \\
\text { longo de um ano }\end{array}$ & Resíduos produzidos \\
\hline Carvão & $2.500 .000 \mathrm{~kg}$ & $\begin{array}{c}5.000 .000 \mathrm{~kg} \mathrm{de} \mathrm{CO}_{2}, \mathrm{SO}_{2}, \\
\text { cinzas e metais pesados } \\
\text { liberados para atmosfera }\end{array}$ \\
\hline Óleo & $1.500 .000 \mathrm{~kg}$ & $\begin{array}{c}4.800 .000 \mathrm{~kg} \text { de } \mathrm{CO}_{2}, \mathrm{SO}_{2}, \mathrm{e} \\
\text { outros }\end{array}$ \\
\hline Gás Natural & $700.000 \mathrm{~kg}$ & 2.400 .000 de $\mathrm{CO}_{2}$ \\
\hline Nuclear & $25 \mathrm{~kg}$ de urânio enriquecido & $\begin{array}{c}23 \mathrm{~kg} \text { de resíduos (apenas 1 } \\
\mathrm{kg} \text { de resíduos de alta } \\
\text { atividade) }\end{array}$ \\
\hline
\end{tabular}

Fonte: Brasil Nuclear, Julho/2007, nº 31, página 16

Segundo Rosa, do ponto de vista ambiental, a energia nuclear tem hoje a vantagem de não emitir gases do efeito estufa. As termelétricas emitem muito dióxido de carbono usando combustíveis fósseis como carvão, petróleo e gás natural. Quanto às hidrelétricas, embora suas emissões fossem consideradas desprezíveis, estudos realizados nos reservatórios de pesquisas no Instituto 
Virtual Internacional de Mudanças Globais da Coppe-UFRJ, mostraram que elas emitem metano e dióxido de carbono, embora, em geral, menos de que as termelétricas (Rosa, 2007).

Para Shreve \& Brink Jr a demanda crescente de energia, combinadas com a dificuldade de acesso a fontes de petróleo e gás, proporcionou uma corrida em direção aos suprimentos de urânio, tornando o investimento em usinas nucleares uma grande alternativa (Shreve \& Brink Jr, 1977).

A energia nuclear é obtida através da fissão do isótopo de Urânio 235 (físsil) em dois ou mais elementos. Essa quebra produz, além de 2 a 3 nêutrons que possibilitam manter a reação em cadeia, uma grande quantidade de calor, que pode ser usada para a geração de energia elétrica por meio de reatores nucleares de potência. O Brasil optou pelos reatores do tipo PWR (Pressurzed Water Reactor) que usa o urânio enriquecido no isótopo ${ }^{235} \mathrm{U}$ e água natural. Para Wakil (1971), a água desse tipo de reator tem múltiplas funções: resfriamento, moderador e refletor. A água é uma substância apropriada para a transferência de calor porque é segura, e tem boas propriedades físico-químicas.

Uma central de energia nuclear de $1000 \mathrm{MW}$ representa uma economia anual de 1,6 bilhões de litros de petróleo e produz 5 bilhões de kW de eletricidade que pode ser utilizada em 650.000 residências. A FIG. 10 mostra a comparação da quantidade de energia gerada por uma pastilha de urânio com outras fontes de energia.

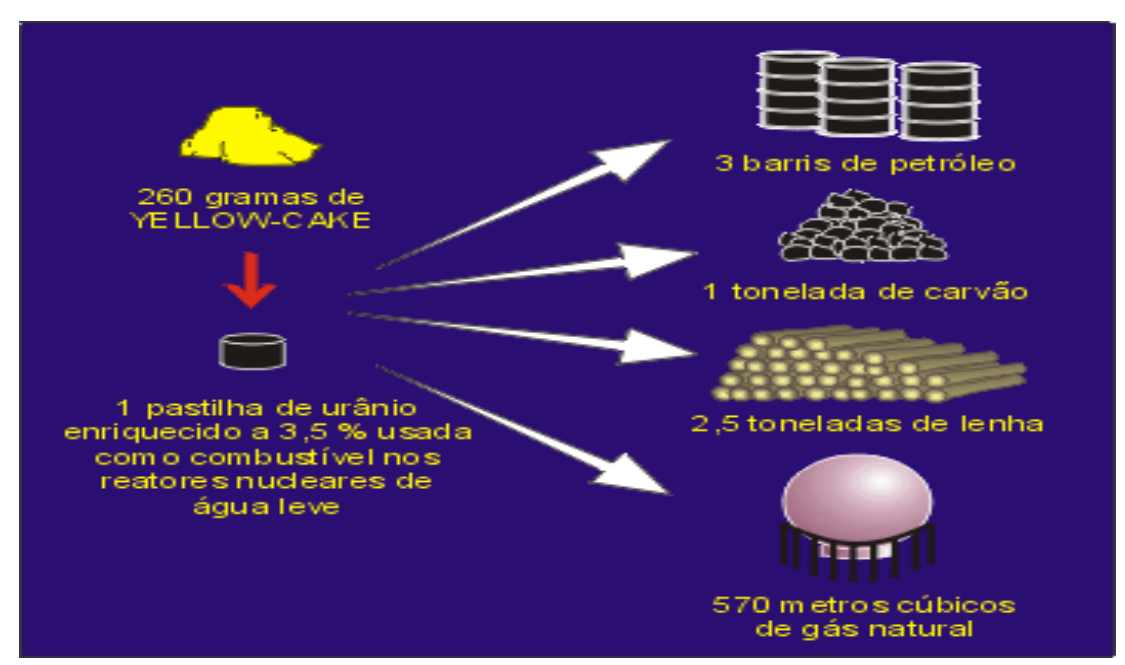

FIGURA 10 - Comparação das fontes de energia

Fonte: www.mar.mil.br/ctmsp/nav_usi_sub_nocoes/energia.htm 


\subsection{Energia nuclear no Brasil}

A produção de eletricidade através de reatores nucleares começou no Brasil como uma opção ao uso de combustíveis fósseis. A opção por outra fonte de energia foi marcada pela crise do petróleo em 1973, provocada pelo embargo da distribuição do petróleo para os Estados Unidos e países da Europa feita por países membros da Organização dos Países Exportadores de Petróleo (OPEP): Arábia Saudita, Irã, Iraque e Kuwait, desestabilizando a economia mundial.

Conforme Cassedy \& Grossman, a crise de energia começou de forma dramática devido às guerras entre árabes e israelitas. Nações árabes repentinamente cortaram todas as remessas de petróleo para os Estados Unidos, aliado de Israel. Durante as semanas seguintes, os americanos sofreram um desconforto antes nunca sentido: milhões de pessoas em seus carros, esperando em fila o abastecimento de gasolina. Desde a Segunda Guerra Mundial, os americanos possuíam uma provisão abundante de recursos de energia barata, especialmente petróleo, eles tinham criado uma sociedade extremamente consumista de energia que sofreu a mesma escassez encontrada em todos os lugares (Cassedy \& Grossamn, 1990).

Mas o embargo teve implicações mais sérias do que o desconforto de filas em postos de gasolina. Os americanos começaram a perceber a quantidade de energia que eles realmente precisavam. A imprensa encheu-se repentinamente de estatísticas preliminares sobre os milhões de barris de petróleo consumidos pelos Estados Unidos e que era a nação que mais consumia essa fonte de energia. As pessoas perceberam, que muito daquele petróleo era importado, os recursos de energia eram controlados por outros países e que o suprimento poderia ser cessado a qualquer momento.

Como o Brasil já pesquisava sobre a área nuclear, ficou fácil a tomada de decisão para diminuir sua dependência para suprimento de energia, estudando as alternativas possíveis. A estratégia central foi definida: todas as usinas nacionais seriam construídas segundo a tecnologia de um único parceiro, evitando a dispersão de técnicos e maiores dificuldades para a absorção e implantação de uma indústria nuclear. O governo americano, consultado, recusou-se a transferir sua tecnologia nuclear e somente a Alemanha concordou com as exigências brasileiras (Fonseca, 1990). Em junho de 1975 foi assinado o Acordo de Cooperação Nuclear Brasil-Alemanha, visando realizar um programa 
conjunto com esse país para construção de reatores nucleares. Mas uma pergunta precisava ser respondida: quem iria fabricar o combustível nuclear?

Os reatores que os alemães dominavam eram do tipo PWR (Pressurized Water Reactor), que trabalha com urânio enriquecido, mas em decorrência da Segunda Grande Guerra e dos convênios que havia assinado não podia obter material físsil na quantidade requerida para o projeto nem transferiria a tecnologia da ultracentrifugação. Naquela época, a tecnologia alternativa apresentada pela Alemanha se mostrou ineficaz e o enriquecimento isotópico se tornou inviável.

No início de 1980 os brasileiros começaram um programa nuclear paralelo dentro do Instituto de Pesquisas Energéticas Nucleares (IPEN), iniciando com estudos e pesquisas de enriquecimento por ultracentrifugação e com o Projeto Conversão (construção de uma fábrica de hexafluoreto de urânio).

Para otimizar as operações de uma usina nuclear, em assuntos como licenciamento, construção, fiscalização, operação, distribuição de energia e outros, o governo do Brasil comprou, nos anos 70, uma usina americana fabricada pela Westinghouse denominada Angra 1, montada em Angra do Reis, situada no Rio de Janeiro. A FIG. 11 mostra as instalações nucleares de Angra 1, localizada na cidade de Angra dos Reis, RJ.

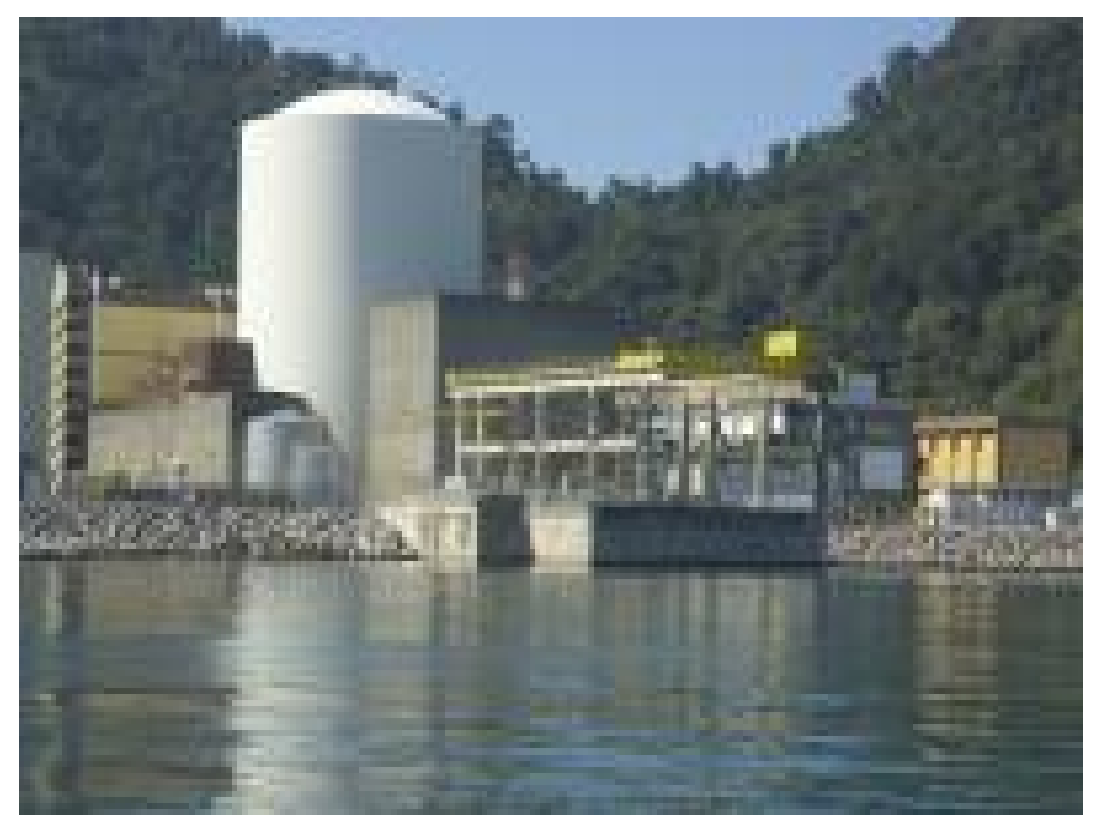

FIGURA 11 - Instalações nucleares de Angra 1

Fonte: http://www.miggo.com.br/clientes/eletronuclear/index.php?tipo=Fotos 
Esta unidade é operada pela Eletronuclear e foi inaugurada em 1983. Posteriormente, foi construída Angra 2, já dentro do convênio Brasil-Alemanha, sua capacidade é o dobro de Angra 1, com 1350 MW de potência. Juntas, as usinas nucleares representam 2,05\% da oferta atual de energia elétrica para 0 país ${ }^{1}$. Na FIG. 12 é mostrada uma vista aérea do local das usinas nucleares em Angra dos Reis, RJ.

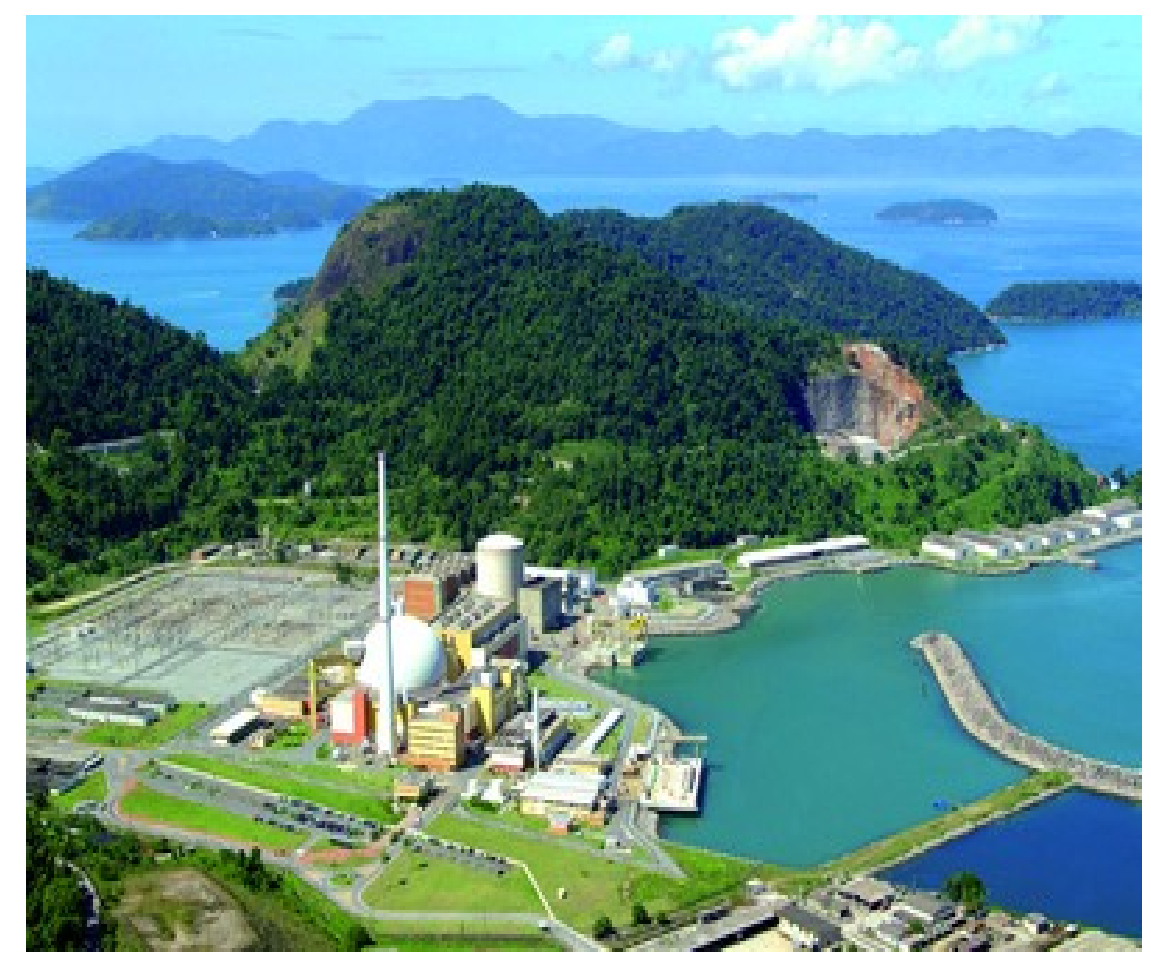

Figura 12 - Vista aérea das usinas nucleares de Angra dos Reis Fonte: http://www.wegweiser.de

Segundo Dantas, o Conselho Nacional de Política Energética (CNPE) aprovou, em junho de 2007, a retomada das obras da usina nuclear Angra 3, bem como o Plano Nacional de Energia 2030, elaborado pela Empresa de Pesquisas Energéticas (EPE) que prevê a construção de mais quatro usinas nucleares, para atender ao crescimento da demanda de energia. De acordo com o Plano a participação da energia nuclear na matriz energética, atualmente hidrelétrica, só ganharia impulso a partir de 2025 , até então o crescimento seria gradativo. 0 cronograma projeta o término de Angra 3 em 2013 e a entrada em operação de cada uma das novas usinas a cada cinco anos, sendo a primeira prevista para o

${ }^{1}$ http://www.aneel.gov.br 
período de 2015-2020, outra em 2020 e 2025, e mais duas entre 2025 e 2030. Ao traçar uma estratégia de implantação gradativa de novas usinas, a EPE buscou também atender uma das diretrizes do Programa Nuclear Brasileiro, no sentido de preservar a capacitação adquirida, investir no desenvolvimento tecnológico e garantir a renovação do contingente de recursos humanos do setor (Dantas, 2007).

\subsection{0 urânio}

O urânio é facilmente encontrado na crosta terrestre. É aproximadamente 500 vezes mais abundante que o ouro e tão comum como o estanho. Está presente na maioria das rochas e nos solos, assim como em rios e oceanos. Por exemplo, é achado em concentrações de cerca de quatro partes por milhões (ppm) em granito que compõe 60\% da crosta da Terra. Em fertilizantes, a concentração de urânio pode ser tão alta quanto 400 ppm (0.04\%) e alguns depósitos de carvão contêm urânio a concentrações maiores que 100 ppm $(0.01 \%)^{2}$.

O princípio que norteia as atividades nucleares é que para serem viáveis, não se pode gastar mais energia no ciclo do combustível do que a quantidade que vai ser gerada na usina quando em operação (balanço de energia). Por isso ao lado de uma mina de urânio sempre existe uma fábrica de concentrado denominado yellow cake. Porque o urânio ocorre na natureza em baixas concentrações, um minério contendo $0,2 \%$ de urânio é considerado rico. Imagine um fábrica de concentrado longe da mina, 99,8\% de material sem interesse seria transportado junto com o urânio, ou seja, 998 kg de estéril para cada 2 kg de urânio.

O nome urânio é em homenagem ao planeta Urano. Trata-se de um elemento químico de símbolo $U$, cuja massa atômica é igual a 238 (92 prótons e 146 nêutrons).

Além de ser utilizado como combustível nuclear para a produção de energia elétrica, o urânio tem outras aplicações como: material para instrumentos de orientação inercial como giroscópio; produção de raios $X$ de alta intensidade; blindagens; acetato é usado em análises químicas e alguns sais são empregados

\footnotetext{
${ }^{2}$ The Nuclear Fuel Cycle, Information papers, January 2007
} 
na produção de vidros amarelos. Na FIG. 13 é mostrada uma das aplicações do urânio, o giroscópio.

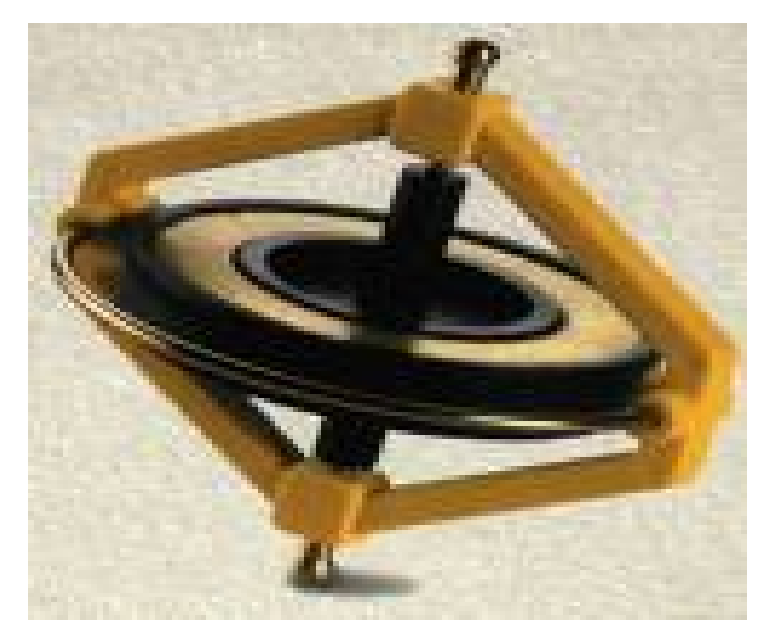

\section{FIGURA 13 - Giroscópio}

Fonte: www.bresciascienza.it/.../cult/science_shop.htm

Segundo Ishiguro o Brasil tem a sexta posição no ranking mundial de reserva de urânio, com aproximadamente 300 mil toneladas, podendo aumentar sua posição, porque nem todo o território foi prospectado (Ishiguro, 2002). Atualmente, o urânio é extraído da mina de Caetité, na Bahia, sendo transformado no hexafluoreto de urânio no Canadá, mas futuramente o Brasil terá condições de terminar sua Usina de Hexafluoreto de Urânio. Na Fig. 14 são indicadas as reservas brasileiras de urânio no Brasil.

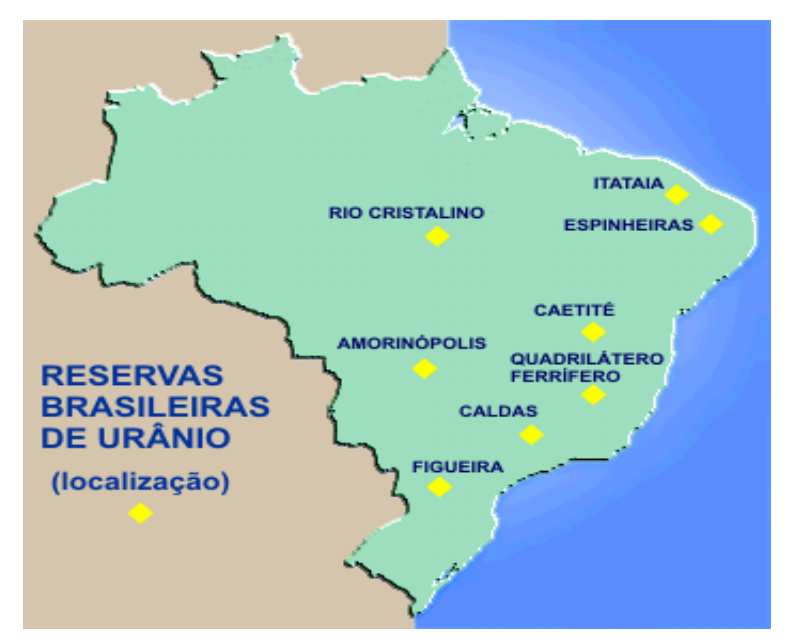

Figura 14 - Reservas brasileiras de urânio

Fonte: www.territorioscuola.com 


\subsection{Ciclo do combustível nuclear}

Combustível nuclear é todo material que contém uma fração fissionável e que é passível de uso em um reator nuclear para a geração de energia elétrica ou em reator de pesquisa para a obtenção de fluxo neutrônico adequado para a produção de radioisótopos de interesse, ou para estudo de materiais. Para isso é necessário manter uma reação em cadeia, o que pode conseguido usando o urânio natural ou enriquecido, ou ainda material físsil obtido em outros reatores, tais como ${ }^{233} \mathrm{U}$ e ${ }^{239} \mathrm{Pu}$.

A produção da energia nuclear requer mais do que um sistema de vapor por reator nuclear, associado a uma turbina geradora, necessários para a produção de energia elétrica a partir do calor criado pela fissão nuclear. Todos os passos do processo devem ser especificados, porque cada um envolve diferentes tecnologias, aspectos econômicos, de segurança e ambientais. No ciclo do combustível existem duas classes de ciclo: a "aberta" e a "fechada". Na "aberta" o combustível gasto descarregado do reator é tratado como rejeito. No ciclo "fechado" o combustível gasto descarregado do reator é reprocessado, e os produtos são separados como urânio (U) e Plutônio (Pu) prontos para a fabricação do óxido combustível ou mescla de óxido combustível (MOX) para serem reciclados no reator ${ }^{3}$.

O combustível é uma peça fundamental na operação eficiente e segura dos reatores nucleares, por isso, segurança, confiança, economia e qualidade são características intrinsecamente ligadas ao combustível nuclear.

Para a utilização do urânio como combustível nuclear em usinas geradoras de eletricidade, é necessário que ele sofra vários processos de transformações químicas e físicas, desde a sua mineração, queima no reator até a sua disposição final (Harrington \& Ruehle, 1969), o que constitui o ciclo do combustível nuclear.

A FIG. 15 mostra o diagrama simplificado do processamento do urânio, da mineração até a produção de hexafluoreto de urânio..

\footnotetext{
${ }^{3}$ The future of Nuclear Power. An Interdisciplinary MIT Study. Massachusetts, 2003
} 


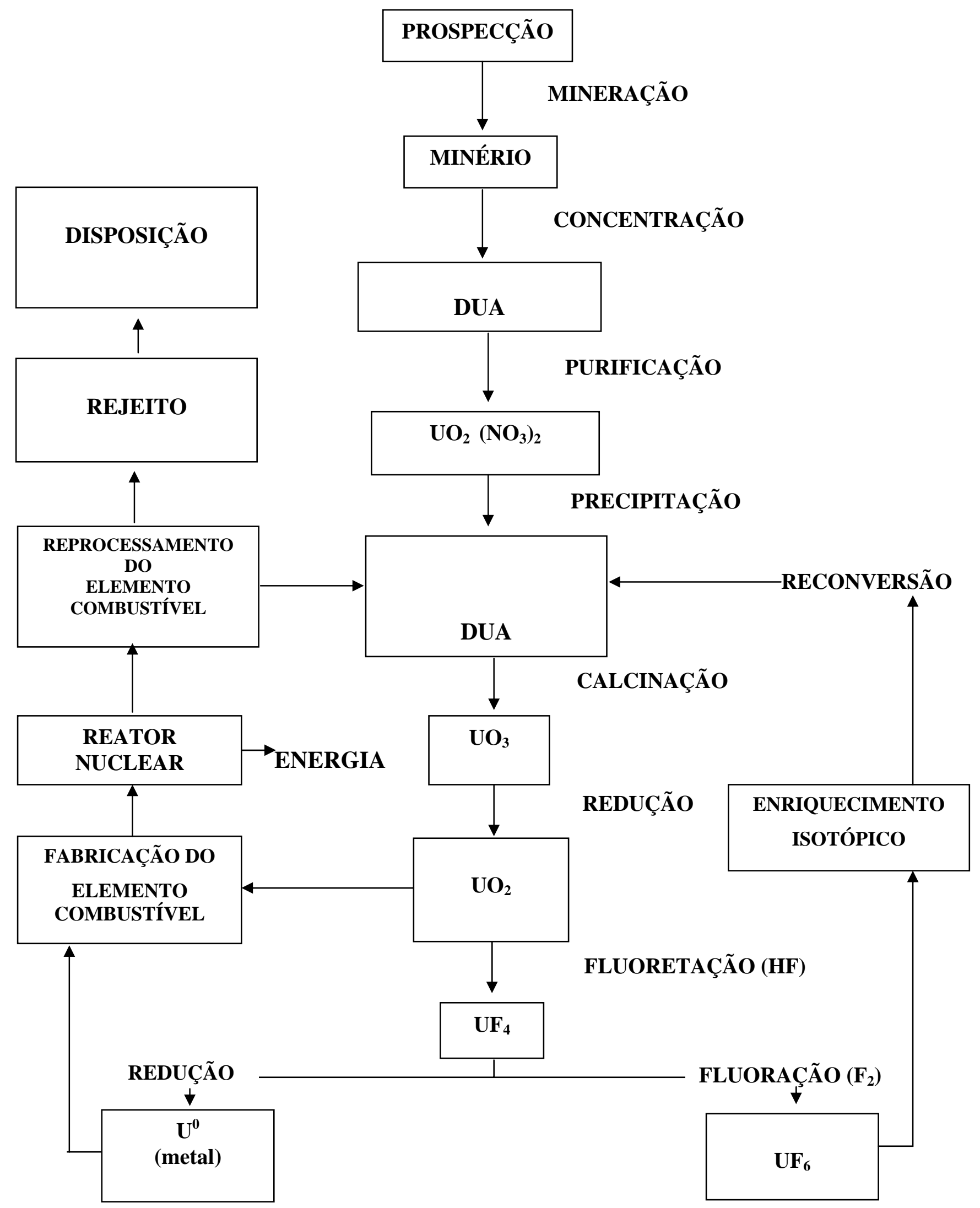

Figura 15 - Diagrama esquemático do ciclo do combustível nuclear de urânio. 
A necessidade dos processos industriais e serviços, chamados etapas do ciclo, são obrigatórios devido a duas características básicas deste combustível: a forma em que ele é queimado na usina é bastante diferente da forma em que ele é encontrado na natureza, e após ser queimado passa a apresentar intensa radioatividade que é prejudicial ao meio ambiente.

Os combustíveis nucleares caracterizam-se pela presença de um isótopo capaz de sofrer fissão nas condições neutrônicas estabelecidas no reator. O urânio- 235 é o isótopo físsil de interesse comercial e técnico para a geração de energia elétrica.

Comercialmente o urânio concentrado é distribuído sob a forma química de diuranato de amônio (DUA) o yellow cake. Após a obtenção do yellow cake, este precisa sofrer diversas transformações químicas até chegar à forma de hexafluoreto de urânio $\left(\mathrm{UF}_{6}\right)$, único produto de urânio estável na forma gasosa sob condições razoáveis de temperatura e pressão, a fim de ser enriquecido isotopicamente (Glasstone, 1975).

Na natureza o urânio é encontrado basicamente com 0,71\% de urânio235 e 99,29\% de urânio-238. Como o isótopo físsil é o do urânio-235 e em um reator de potência tipo PWR a concentração de 0,71\% é insuficiente para manter a reação em cadeia, torna-se necessário processar o enriquecimento isotópico do urânio (Wilson, 1996).

É comum a divisão do ciclo do combustível nuclear em blocos de atividades, cujos principais são descritos a seguir:

Mineração: esta etapa vai da prospecção até a fabricação do concentrado de urânio, yellow cake, e se caracteriza por ser toda ela realizada no próprio local da mina. A prospecção de urânio tem o objetivo de localizar, avaliar e medir reservas de urânio. Os trabalhos começam pela seleção de áreas promissoras, indicadas por exame de fotografias aéreas, imagens de radar e de satélites. Na FiG. 16 é mostrado o minério de urânio. 


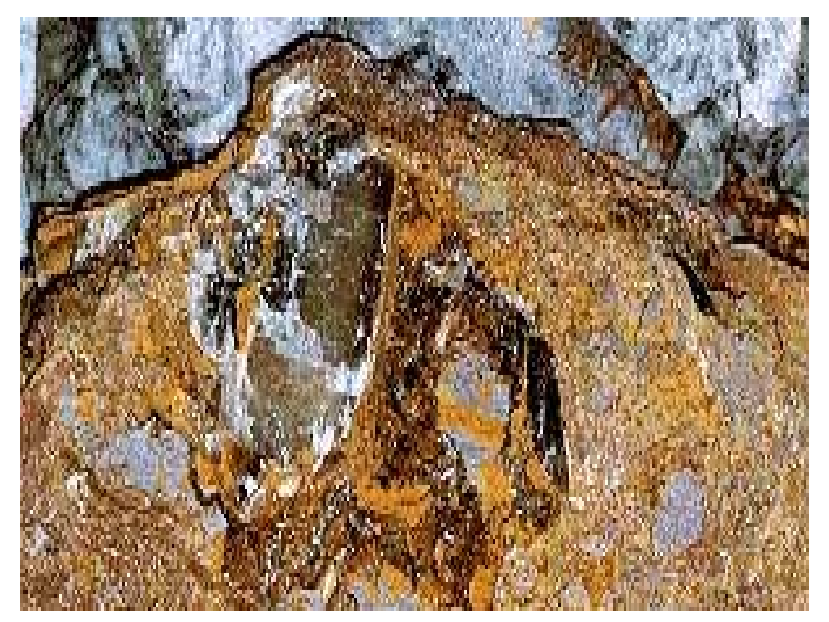

FIGURA 16 - Minério de Urânio

Fonte: http://www.colegiosaofrancisco.com.br/alfa/energia-nuclear/minerio-de-uranio.php

O minério de urânio é retirado da mina e após esse processo de extração é enviado para usina de beneficiamento. O urânio, depois de britado, é colocado em pilhas e, para separação do minério, ocorre o processo de lixiviação com ácido sulfúrico, conforme é mostrado na FIG 17.

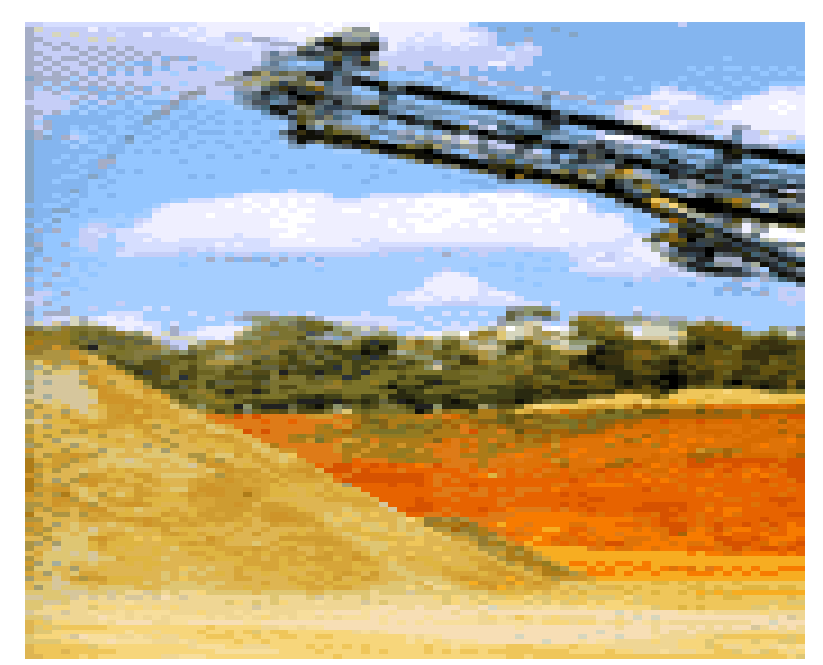

FIGURA 17 - Lixiviação

Fonte: www.inb.gov.br

O urânio é concentrado e purificado por extração com solvente, e depois é precipitado com amônia dando origem ao yellow cake (FIG. 18), que se apresenta com um sal de cor amarela. 


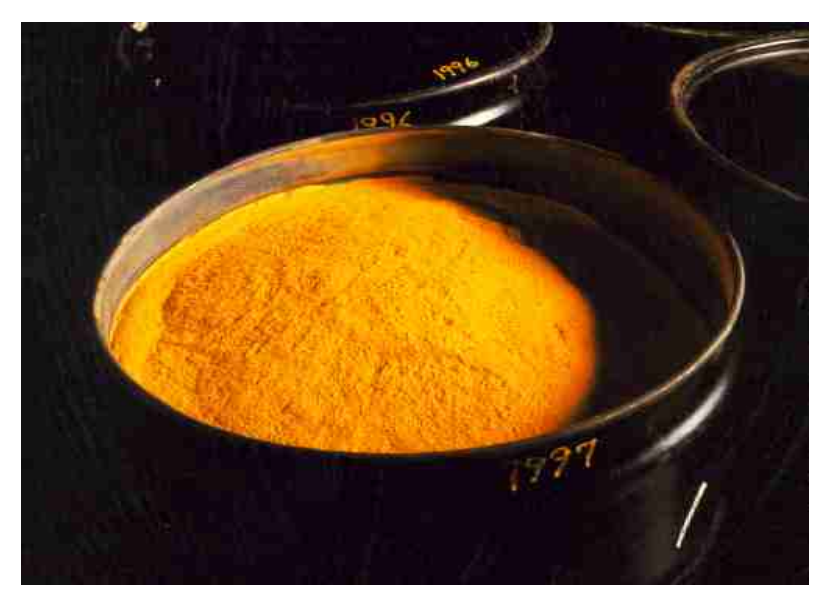

\section{FIGURA 18 - Yellow Cake}

Fonte: http://news.bbc.co.uk/1/shared/spl/hi/sci_nat/05/nuclear_fuel/html/conversion.stm

Conversão: esta etapa vai do concentrado de urânio até a fabricação do hexafluoreto de urânio. O urânio sob a forma de yellow cake é dissolvido e purificado por extração com solventes para obtenção do chamado "grau nuclear". Depois, após algumas etapas intermediárias, é convertido para o estado gasoso, o $\mathrm{UF}_{6}$, para poder fazer as outras transformações. A FIG. 19 apresenta um cilindro contendo $\mathrm{UF}_{6}$.

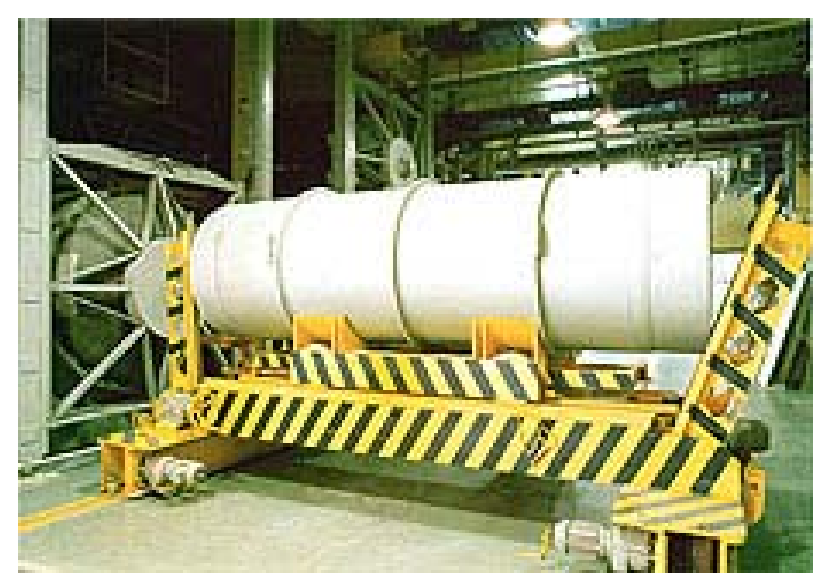

FIGURA 19 - Cilindro típico (modelo 48Y) para estocagem e transporte de $\mathrm{UF}_{6}$. Fonte: www.inb.gov.br

Enriquecimento isotópico: esta etapa é constituída de uma única atividade, que no caso brasileiro é realizada usando a técnica de ultracentrifugação, cujo esquema é mostrado na FIG. 20. 


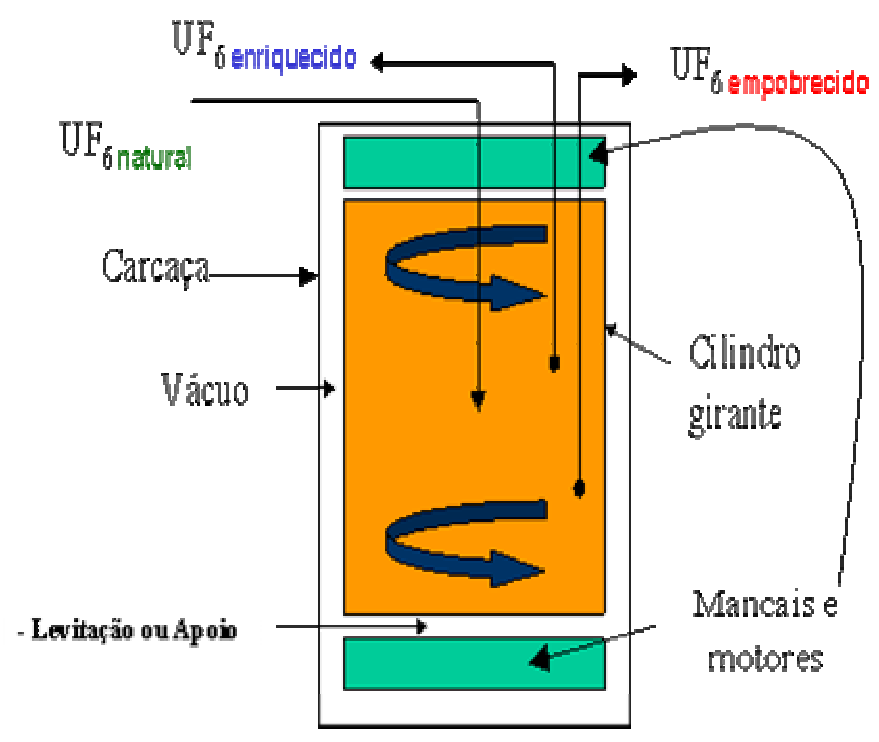

FIGURA 20 - Esquema de ultracentrifugação

Fonte: http://ecen.com/eee54/eee54p/enriquec_uranio_brasil.htm

Reconversão: esta etapa compreende a transformação do hexafluoreto de urânio, que é um gás, já enriquecido isotopicamente, ao estado sólido sob a forma de pó, o dióxido de urânio $\left(\mathrm{UO}_{2}\right)$. Na FIG. 21 é mostrado o dióxido de urânio.

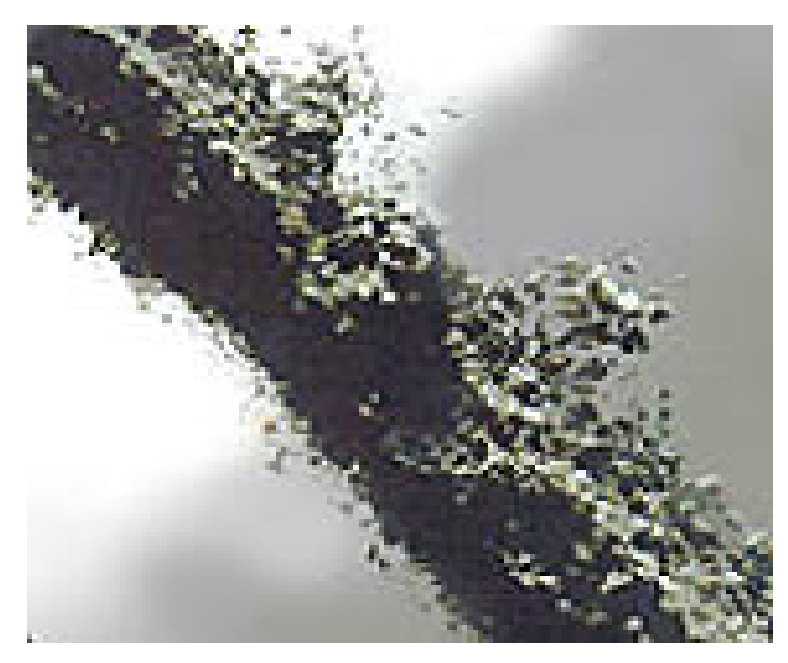

FIGURA 21 - Dióxido de urânio

Fonte: www.inb.gov.br

Fabricação do elemento combustível: esta etapa inclui a fabricação das pastilhas de dióxido de urânio (FIG. 22) e montagem do elemento combustível (FIG. 23). 


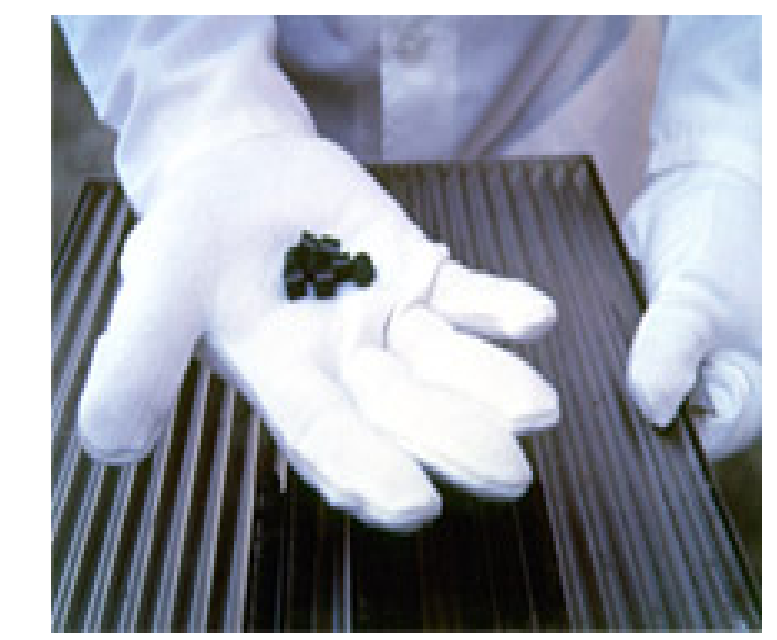

FIGURA 22 - Pastilha de dióxido de urânio

Fonte: www.inb.gov.br

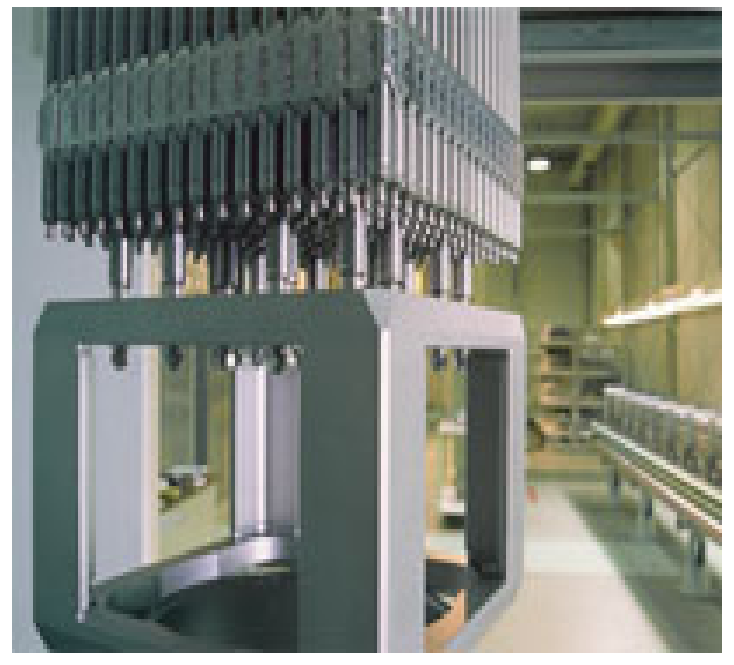

FIGURA 23 - Elemento combustível

Fonte: www.inb.gob.br

Reprocessamento do combustível irradiado: esta etapa abrange desde o desmonte mecânico do combustível irradiado até a separação dos rejeitos radioativos do urânio não consumido no reator.

Tratamento de rejeitos radioativos: esta etapa consiste no acondicionamento e disposição dos rejeitos radioativos.

\subsection{Unidade de Produção de Hexafluoreto de Urânio (USEXA)}

Conforme mencionado no Capítulo 5, para atender às necessidades experimentais do programa de pesquisa e desenvolvimento do CTMSP, funciona 
em Iperó, o Centro Experimental Aramar. Uma das instalações existentes é a Unidade de Produção de Hexafluoreto de Urânio (USEXA), compreendendo a etapa de Conversão do ciclo do combustível nuclear.

A instalação completa da USEXA é composta de várias unidades de processo, de utilidades e de apoio, cada uma prevista para realizar uma determinada etapa do processo. Os processos compreendem resumidamente as seguintes seqüências de etapas químicas: purificação do concentrado de urânio obtendo-se nitrato de uranilo (NTU); produção de trióxido de urânio $\left(\mathrm{UO}_{3}\right)$, por meio de reações químicas e calcinação; produção de tetrafluoreto de urânio $\left(U_{4}\right)$, por meio de reações químicas com ácido fluorídrico e outros elementos em ambiente controlado; produção de flúor $\left(F_{2}\right)$ em células eletrolíticas a partir do ácido fluorídrico (HF); produção e purificação de hexafluoreto de urânio (UF $)_{6}$, por meio da reação do $U_{F_{4}}$ com $F_{2}$ em reatores específicos. A previsão da produção é de 40 toneladas de hexafluoreto de urânio, visando atender às necessidades do Programa Nuclear da Marinha e também podendo atender parte das necessidades das Indústrias Nucleares do Brasil (INB).

\subsection{Etapa de Conversão do ciclo do combustível nuclear}

O produto de uma fábrica de urânio não é diretamente usado como combustível no reator nuclear. Para isso é necessário que ele seja convertido. 0 termo "conversão" refere-se ao processo de purificação do concentrado do urânio que o transforma na forma requerida para o próximo estágio do ciclo do combustível.

O hexafluoreto de urânio é o produto predominante nesta etapa do ciclo do combustível, uma vez que ele é convertido para o estado gasoso. De acordo com Cochran \& Tsoulfanidis $0 \quad U_{6}$ foi selecionado por causa de suas propriedades especiais. O fato de ser sólido na temperatura ambiente facilita 0 seu manuseio, e em temperaturas levemente elevadas torna-se vapor, sendo ideal para o processo, que requer o urânio em uma forma química estável, no estado gasoso, sob condições razoáveis de temperatura e pressão para separação isotópica (Cochran \& Tsoulfanidis, 1992).

Para isso, existe a necessidade de traçar uma rota química para chegar até $\mathrm{o} \mathrm{UF}_{6}$ e obter um produto com os requisitos de pureza exigidos para sua 
aplicação nuclear, com a maior economia de energia possível. As etapas envolvidas nesse trajeto são:

1) Purificação do urânio: justificada pela necessidade da obtenção de um material com o chamado "grau nuclear". Visa à remoção de impurezas capazes de absorverem os nêutrons do sistema, consequentemente diminuindo o rendimento de fissão do urânio-235 e impedir a presença de outras impurezas que comprometam as propriedades cerâmicas e mecânicas do combustível nuclear. A técnica adotada é a extração com solvente em coluna pulsada. O solvente, no caso, é o tri-n-butil fosfato TBP. O processo é operado em um sistema com três colunas onde a primeira é de extração, a segunda de lavagem e a terceira de reversão (térmica). O produto final é uma solução de nitrato de uranilo com cerca de $100 \mathrm{gU} / \mathrm{L}$.

2) Precipitação do DUA: justificada pela necessidade de se trabalhar com volumes menores. A solução de $100 \mathrm{gU} / \mathrm{L}$ corresponde a uma estocagem de $100 \mathrm{~kg} / \mathrm{m}^{3}$, enquanto sob a forma sólida este valor pode ser 20 vezes maior. Também são minimizados os problemas de corrosão e vazamento, melhorando a segurança. O DUA quando calcinado gera somente $\mathrm{UO}_{3}$.

3) Fabricação de tetrafluoreto de urânio: justificada pela necessidade de se economizar energia elétrica no ciclo. Para preparar o $U_{6}$ é preciso flúor obtido por eletrólise do ácido fluorídrico, enquanto que a preparação do $\mathrm{UF}_{4}$ pode ser feita usando diretamente o HF, que é obtido pela reação fluorita. O reator utilizado na produção do $U_{4}$ é do tipo leito móvel e se caracteriza por ter duas regiões distintas: redução de $\mathrm{UO}_{3}$ e fabricação do $\mathrm{UF}_{4}$.

4) Fabricação do hexafluoreto de urânio: etapa necessária para obter o urânio na forma química adequada para realizar o enriquecimento isotópico.

5) Enriquecimento isotópico: o enriquecimento isotópico em urânio-235 é uma das etapas do ciclo do combustível nuclear necessária para quem pretende fabricar elementos combustíveis para reatores de pesquisas e/ou PWR. Três são os principais processos adotados para aumentar a fração de urânio-235, que na natureza é de 0,7\%, para 4,2\%, concentração usada nos reatores PWR: difusão gasosa, ultracetrifugação e jato centrífugo. O jato centrífugo é um processo de enriquecimento isotópico que foi 
modelado pela Alemanha e transferido para o Brasil dentro do convênio firmado entre os dois países para o desenvolvimento conjunto de programa com finalidade de gerar energia elétrica. Nos anos 80 ainda não existia tecnologia para fabricar os equipamentos necessários para o domínio desse processo físico-químico. Outra iniciativa foi tomada com a criação do Projeto Paralelo, gerenciado pela Marinha do Brasil e, inicialmente, fazendo uso do quadro de pesquisadores do IPEN. A tecnologia adota nesse caso foi a da ultracentrifugação. O projeto atingiu o seu objetivo conseguindo colocar o Brasil no seleto grupo dos detentores da tecnologia do enriquecimento isotópico do urânio-235.

Cinco países operam em escala comercial a Conversão do concentrado de urânio para o hexafluoreto de urânio: Canadá, França, Rússia, Reino Unido e Estados Unidos da América.

Dados da International Atomic Energy Agency (IAEA), Vienna, 2001, constatam que no Canadá, a Cameco opera a planta de Port Hope (Capacidade de 12.500 t de U/a). Na França, a Comurhex opera as plantas de Malvesi e Pierrelatte (capacidade total de 14.000 t U/a). Na Rússia, a Minaton opera as plantas de Sverdlovsk e Angarsk (capacidade total de 34.000 t U/a). No Reino Unido, a British Nuclear Fuels (BNFL) opera a planta de Sprigfields Line 4 (capacidade de $6.000 \mathrm{t}$ de U/a) e nos Estados Unidos, a Honneywell International opera a planta de Metropolis (capacidade de 12.700 t de U/a). 


\section{MATERIAIS E MÉTODOS}

Para Gil, define-se pesquisa como o procedimento racional e sistemático que tem o objetivo de proporcionar respostas aos problemas que são propostos. A pesquisa é desenvolvida mediante o concurso dos conhecimentos disponíveis e a utilização cuidadosa de métodos, técnicas e outros procedimentos científicos. Na elaboração de uma pesquisa, descobre-se que trata-se de um universo vasto, aberto e que para compreendê-lo é necessário muito tempo de estudo e dedicação para a correta interpretação e entendimento dos autores e construção de metodologias próprias. O material coletado pode apresentar diferentes focos tais como: áreas de saúde e biológicas, pesquisas sociais (na área de humanas) e pesquisas de mercado, além das ciências ditas como exatas. Dependendo da atividade de cada autor, essa diferenciação ocorre tanto do ponto de vista da elaboração, quanto da análise, interpretação, rigor científico, generalizações e conclusões a respeito do assunto abordado (Gil, 2002).

Em relação à forma de abordagem, defini-se pesquisa quantitativa como a que traduz em números as opiniões e informações tornando possível classificá-las e organizá-las; já, a pesquisa qualitativa é mais descritiva e utiliza o método indutivo.

O estudo de caso caracteriza-se como um tipo de pesquisa cujo objeto é uma unidade analisada profundamente. Conforme Godoy, o propósito fundamental do estudo de caso (como tipo de pesquisa) é analisar intensivamente uma dada unidade social (Godoy, 2005).

Segundo Yin apud Godoy, o estudo de caso é a única forma de se fazer pesquisa empírica por investigar fenômenos contemporâneos dentro de seu contexto de vida real e em situações cujas fronteiras entre o fenômeno e o contexto não estão claramente estabelecidas. Com o objetivo de aprofundar a descrição de determinado fenômeno, o investigador pode optar pelo estudo de situações típicas (similares a muitas outras do mesmo tipo) ou não-usuais (casos excepcionais) (Yin apud Godoy, 1995).

Nesse trabalho, foi realizada uma abordagem quantitativa, a qual consiste de um levantamento estatístico, com o objetivo de se obter as características dos gastos efetuados desde o início da USEXA, e, também, com intuito de corroborar as hipóteses levantadas. Existe, para este trabalho, uma 
base empírica, pois esse tipo de estudo trabalha com dados mensuráveis obtidos numa amostra "deteriorada" com o passar do tempo, em função das inúmeras variações nacionais da moeda corrente.

Além disso, foram consultadas diferentes bases de dados sobre as áreas ambiental, química e contábil. Foram realizadas visitas à USEXA, consultado o banco de dados histórico da organização, entrevistas com o pessoal envolvido no projeto e realizada leitura do Relatório Preliminar de Análise de Segurança (RPAS).

A escolha da Contabilidade Ambiental no ciclo do combustível nuclear foi determinada pela possibilidade da aplicação do Balanço Ambiental na etapa de Conversão e pelo fácil acesso aos coordenadores e profissionais envolvidos no projeto.

\subsection{Infraestrutura}

A infraestrutura utilizada foi a instalação do Centro Tecnológico da Marinha em São Paulo. Primeiramente, as visitas a USEXA no Centro Experimental Aramar; depois uso do acervo da biblioteca; microcomputadores com acesso ao sistema de suprimentos, Internet, utilização de documentos da Coordenadoria do Ciclo do Combustível Nuclear. A FIG. 24 mostra a estrutura hierárquica da Coordenadoria do Ciclo do Combustível Nuclear.

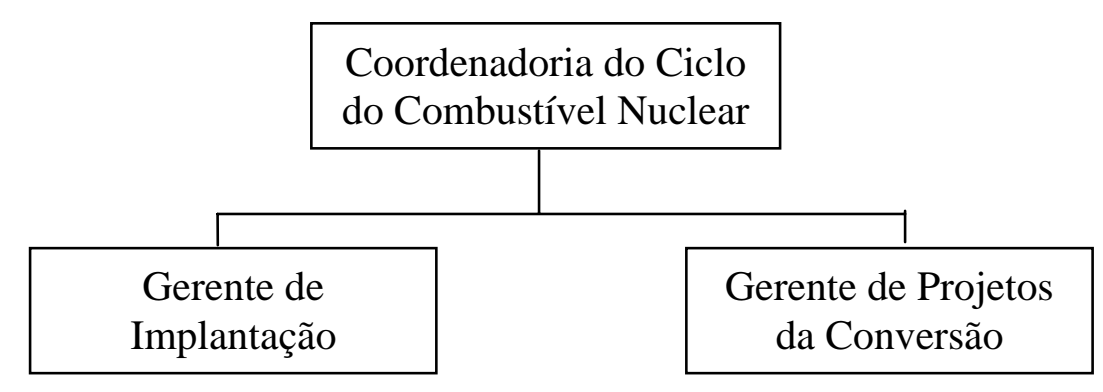

FIGURA 24 - Organograma da Coordenadoria do Ciclo do Combustível Nuclear

As informações no banco de dados do CTMSP foram coletadas na Divisão de Controle e Orçamento, subordinada à Superintendência Financeira, conforme mostrada na FIG. 25: 


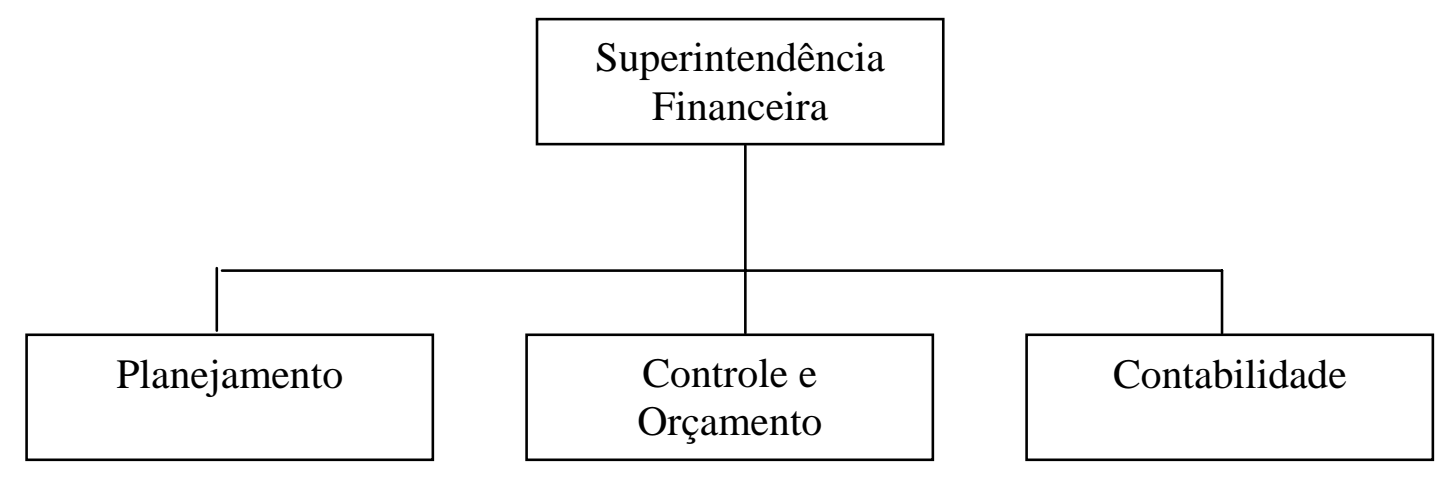

FIGURA 25 - Organograma da Superintendência Financeira 


\section{ESTUDO DE CASO}

Uma das etapas do ciclo do combustível nuclear é a obtenção de hexafluoreto de urânio nuclearmente puro, a partir do concentrado de urânio natural, o yellow cake. Segundo Grippi, a produção no passado era obtida a partir da mineração na cidade de Poços de Caldas, em Minas Gerais, com a capacidade média de 2.000 toneladas de minério/dia, suprindo as demandas de Angra I e as fases de pesquisas tecnológicas. Atualmente, a grande produção nacional é proveniente da cidade de Caetité, na Bahia, onde a INB prospecta urânio na mina de Lagoa Real. A FIG. 26 mostra uma vista aérea da Usina da INB (Grippi, 2008).

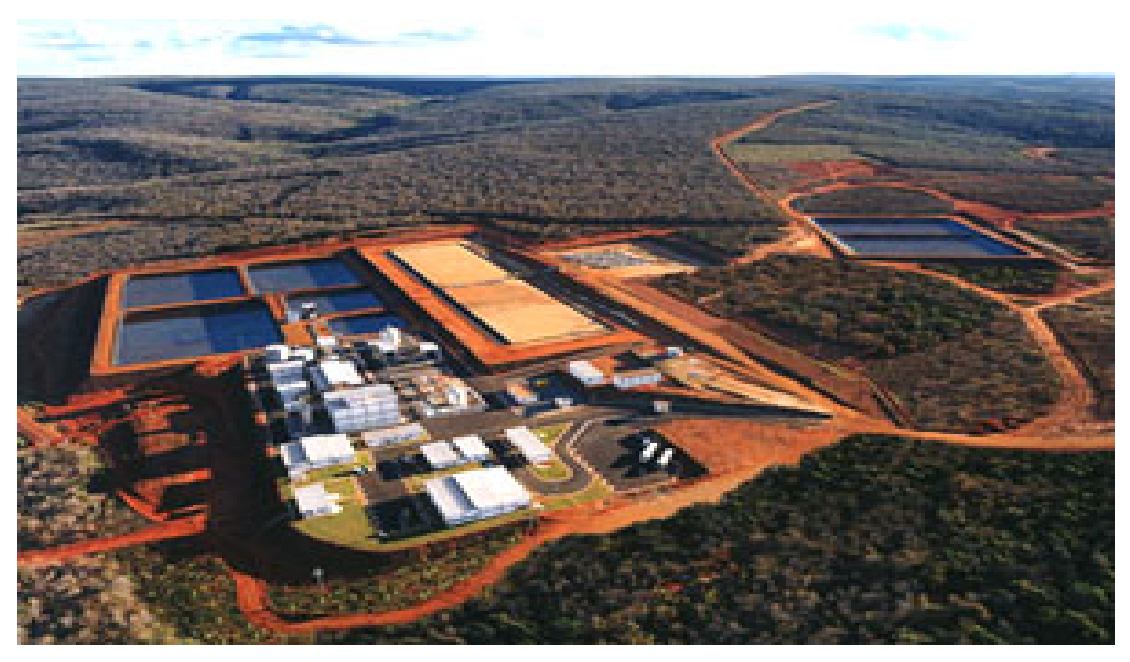

FIGURA 26 - Vista aérea das instalações da INB em Caetité-BA.

Fonte: www.inb.gov.br

O material nuclear a ser manuseado como matéria-prima é o concentrado de urânio, composto basicamente por diuranato de amônio (DUA) e impurezas. A partir de um conjunto de processos químicos, este material é transformado em hexafluoreto de urânio $\left(U_{6}\right)$. Depois disso, o produto será enriquecido pelo processo de separação isotópica nas ultracentrífugas já em plena operação no Brasil. Posteriormente, serão reconvertidos em dióxido de urânio, o que possibilitará a fabricação de pastilhas, elementos combustíveis que integrarão o núcleo de um reator nuclear. A implantação da tecnologia de produção de $U_{6}$ em escala industrial é parte importante do esforço nacional na 
busca de autonomia no domínio do complexo ciclo da produção de combustíveis nucleares. A técnica de obtenção laboratorial do $U_{6}$ já foi desenvolvida no Brasil, e o passo seguinte será a sua produção em escala industrial.

O Centro Tecnológico da Marinha em São Paulo, conforme mencionado no Capítulo 5, está implantando, no CEA, a Unidade de Produção de Hexafluoreto de Urânio, denominada USEXA, o objeto do estudo de caso do presente trabalho. A área construída é de aproximadamente $12.000 \mathrm{~m}^{2}$, e atende aos critérios de segurança, preservação do meio ambiente, saúde dos trabalhadores e das instalações físicas.

\subsection{Instalação}

A USEXA é formada por um conjunto de edifícios. Suas unidades de processos são listadas a seguir, e um diagrama esquemático das principais etapas do processo é mostrado na FIG. 27.

- Estocagem de matéria-prima;

- Purificação de nitrato de uranilo (NTU);

- Produção trióxido de urânio $\left(\mathrm{UO}_{3}\right)$;

- Produção de tetrafluoreto de urânio $\left(U_{4}\right)$;

- Produção hexafluoreto de urânio $\left(\mathrm{UF}_{6}\right)$;

- Destilação de hexafluoreto de urânio $\left(U_{6}\right)$;

- Recuperação de Urânio e Tratamento de Efluentes e Rejeitos;

- Produção de Flúor $\left(F_{2}\right)$;

- Estocagem de produtos químicos;

- Estocagem de ácido fluorídrico;

- Edifício administrativo e almoxarifado. 


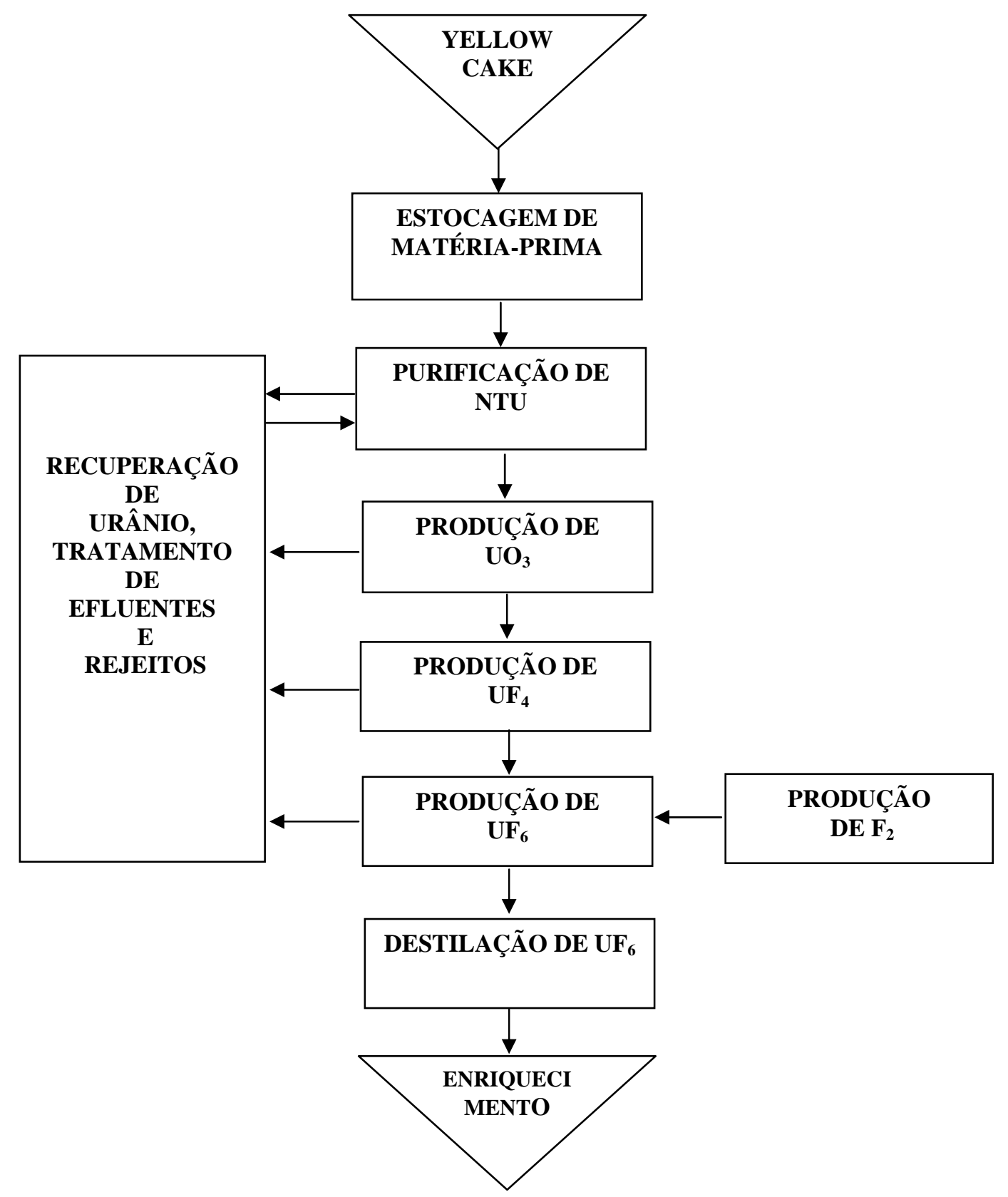

FIGURA 27 - Diagrama simplificado de processo 


\subsection{Processo}

Nesta seção são descritas os processos das diversas unidades que compõe a Unidade de Produção de Hexafluoreto de Urânio do Centro Tecnológico da Marinha em São Paulo.

\section{a) Estocagem de matéria-prima}

Os processos da USEXA iniciam-se na unidade de estocagem de matéria-prima que é responsável pelo recebimento, estocagem e coleta de amostras do concentrado de urânio.

O yellow cake chega através de caminhão baú, dentro de tambores metálicos, e é descarregado sobre paletes por empilhadeiras elétricas e armazenado na área de estocagem de matéria-prima. Depois são devidamente identificados e levados para a área de amostragem.

\section{b) Purificação de NTU}

Essa unidade é responsável pelos processos de dissolução, maturação, filtração e purificação do urânio, partindo do diuranato de amônio para se obter o nitrato de uranilo nuclearmente puro.

Nesta etapa, o yellow cake contido em tambores, após liberação da unidade de estocagem de matéria-prima, abastece um silo de estocagem que alimenta os reatores de dissolução/maturação, feita com um ataque com ácido nítrico o que resulta em uma solução de nitrato de uranilo. As partículas sólidas insolúveis e a sílica (impureza do concentrado) são separadas da solução por filtração à vácuo. Após a filtração, o licor obtido sofre purificação por extração com solvente em colunas pulsadas. O processo é de fase orgânica contínua, permitindo que o solvente contendo produtos de sua degradação seja continuamente recuperado e reutilizado.

\section{c) Produção de $\mathrm{UO}_{3}$}

A solução de nitrato de uranilo purificada e concentrada vinda da unidade de purificação de NTU é enviada para a unidade de produção de $\mathrm{UO}_{3}$.

O nitrato de uranilo é transformado em diuranato de amônio (DUA) mediante reação com amônia gasosa (precipitação). A suspensão de DUA obtida é filtrada a vácuo e a torta gerada, contendo $40 \%$ de sólidos, é seca e calcinada 
em forno elétrico horizontal de esteiras, tipo túnel, com fluxo de ar em contracorrente, produzindo o trióxido de urânio semi-hidratado, sob a forma de plaquetas.

$\mathrm{O} \mathrm{UO}_{3}$ obtido segue para uma peneira equipada com um quebrador para ajustar a granulometria das partículas. Depois do ajuste, o produto é estocado para posterior envio a produção de tetrafluoreto de urânio.

\section{d) Produção de UF $_{4}$}

Esta unidade tem por finalidade obter tetrafluoreto de urânio a partir do trióxido de urânio semi-hidratado.

Nesta etapa do processo, as reações de redução e de hidrofluoração ocorrem no mesmo equipamento: o reator de leito móvel. Neste reator o material sólido alimentado escoa, em contracorrente, com os gases reagentes introduzidos em pontos diferentes.

O trióxido de urânio semi-hidratado alimentado no reator sofre redução em contato com o fluxo gasoso ascendente contendo $\mathrm{H}_{2}$ proveniente do craqueamento da amônia. $\mathrm{O} \cup_{2}$ formado escoa, para o módulo intermediário onde sofre resfriamento, por troca de calor com o ambiente, pela parede do reator.

$\mathrm{Na}$ próxima etapa $\mathrm{o} \mathrm{UO}_{2}$ é convertido em tetrafluoreto de urânio, através da reação com hidrofluoração (HF).

\section{e) Produção de UF 6}

O processo usado para a produção do hexafluoreto de urânio com elevada pureza, parte da síntese direta entre tetrafluoreto de urânio e o flúor elementar, sendo dividido nas seguintes etapas:

- Estocagem e manuseio de material: o UF $_{4}$ é recebido através de um vaso de transporte. Um moinho de martelos ajusta a granulometria do material recebido para alimentação posterior dos reatores de chama e de prato, após estocagem em um silo. O circuito de sólidos contempla também o manuseio de cinzas.

- Fluoração primária: nesta etapa o UF $\mathrm{U}_{4}$, juntamente com as cinzas recicladas no processo, reage com o flúor em excesso no reator de chama, produzindo o $\mathrm{UF}_{6}$. 
- Fluoração secundária: o $\mathrm{UF}_{4}$, juntamente com as cinzas recicladas no processo, reage no reator de pratos com o flúor não convertido no reator de chama e proveniente de um dos cristalizadores primários.

- Cristalização do UF6: essa etapa contempla a retenção sob a forma sólida, do $\mathrm{UF}_{6}$ produzido.

\section{f) Produção de Flúor}

Essa unidade produz o flúor usado no processo por eletrólise de sal fundido em células eletrolíticas de temperatura média. O processo é dividido em preparo e transferência do eletrólito, condicionamento, eletrólise (produção de flúor).

\section{g) Destilação de $U_{6}$}

Sua finalidade é a obtenção do hexafluoreto de urânio puro com qualidade nuclear, a partir de material proveniente da unidade de produção de $\mathrm{UF}_{6} \mathrm{e}$, eventualmente, de $\mathrm{UF}_{6}$ puro reciclado no final do processo.

O sistema de destilação é composto basicamente da Coluna de Destilação; do Condensador da Fração e do Refervedor da Fração Pesada. O condensador tem por finalidade condensar parcialmente a corrente de vapor que sai pela coluna, enquanto o refervedor tem a função de vaporizar a corrente líquida com componentes pesados provenientes do fundo da coluna, ambas as correntes retornam à coluna. O hexafluoreto de urânio é retirado lateralmente da coluna de destilação no estado de vapor saturado. O UF 6 puro é condensado, escoado para um vaso de estocagem e depois transferido para cilindros de estocagem, dotados de sistema de resfriamento.

\section{h) Recuperação de Urânio e Tratamento de Efluentes e Rejeitos}

Unidade responsável pela recuperação de urânio, tratamento, monitoração e controle de todos os rejeitos/efluentes líquidos e sólidos de processo provenientes da USEXA. Independente disso, cada unidade é responsável pelo tratamento dos gases da exaustão do processo. Após o tratamento, os gases limpos são lançados na atmosfera, ou no ponto mais alto do respectivo prédio. Os tambores vazios de concentrado de urânio são lavados com água. A água de lavagem dos tambores, contendo DUA, é enviada para 
tratamento. Os rejeitos sólidos e líquidos das diversas unidades são enviados para tratamento e eventual recuperação de urânio.

\subsection{Materiais nucleares a serem manuseados}

O material nuclear a ser manuseado como matéria-prima é o concentrado de urânio, composto basicamente por diuranato de amônio (DUA) e impurezas. A partir do processo químico via úmida, este material é transformado em hexafluoreto de urânio na sua composição isotópica natural e acondicionado em cilindros de aço.

As reações químicas do processo de Conversão geram diversos compostos de urânio nas formas sólida, líquida e gasosa. A planta química da USEXA é constituída por um conjunto de equipamentos distribuídos de forma a tornar operacional uma seqüência de processos físicos e químicos. Como filosofia de projeto e futura operação da USEXA, todo produto químico/radiativo sempre é manuseado de tal forma que esteja numa barreira de contenção primária (tubulação, vaso de transporte ou equipamentos) auxiliado por um sistema de controle para detecção de condições de operação ou situações anormais. Paralelamente, o manuseio de material químico/radiativo é totalmente efetuado dentro de prédios com ventilação adequada, diminuindo qualquer efeito nocivo ao trabalhador. Qualquer vazamento para a atmosfera é controlado e quantificado.

Em relação à parte ambiental a USEXA atende aos seguintes órgãos:

- CONAMA - Por trabalhar com produtos químicos;

- CNEN - Por ser uma usina nuclear;

- CETESB - Fiscalização.

\subsection{Licenciamento}

De acordo com a legislação em vigor, a localização, a construção e o funcionamento das instalações do CTMSP dependem de autorizações e licenças concedidas por dois órgãos: a CNEN e o IBAMA.

No que se refere ao processo de licenciamento nuclear, os requisitos estão consubstanciados, principalmente, na NE 1.04 (Licenciamento de Instalações Nucleares, publicada pela CNEN), que especifica o conteúdo mínimo de informações, dados de projeto, planos e relatórios que devem ser 
encaminhados aos órgãos reguladores, anexos contendo requerimento de pedidos de aprovações, licenças ou autorizações, relacionados com as instalações.

\subsection{Gerência de rejeitos}

Os resíduos radioativos são os mais perigosos que existem, pois, além de altamente tóxicos, seus efeitos permanecem por longos períodos, impactando as gerações futuras. Durante muito tempo, essa mensagem foi continuamente passada à opinião pública por campanhas contrárias à energia nuclear. Nos últimos anos, no entanto, essas objeções vêm perdendo intensidade frente à preocupação crescente em todo mundo com os danos ao meio ambiente, muitas vezes irreparáveis, provocados pela poluição, desmatamento, emissão dos gases formadores do efeito estufa, entre outros. Em contrapartida, começa a haver uma percepção pública de que a geração nuclear apresenta em relação às demais fontes termelétricas, a vantagem de não provocar a emissão desses gases e, portanto, de contribuir para a redução do aquecimento global (Dantas, 2007).

A USEXA conduzirá operações envolvendo a manipulação e o processamento de compostos de urânio nas formas:

- Gasosa

- Líquido

- Sólido

Esses compostos serão controlados visando à proteção dos trabalhadores, indivíduos do público e do meio ambiente. Do ponto de vista radiológico, apresentam baixa atividade, porque há o manuseio de urânio natural.

\subsubsection{Rejeitos e efluentes gasosos}

O Relatório Preliminar de Análise de Segurança (RPAS) da USEXA, do Centro Tecnológico da Marinha em São Paulo, apresenta uma gerência de rejeitos e efluentes gasosos, com a finalidade de garantir um ambiente propício de trabalho, diminuindo e controlando os produtos nocivos à saúde, e monitorando a emissão de contaminantes para a atmosfera em níveis tão baixos quanto razoavelmente exeqüível. Para isso a USEXA conta com:

- Sistema de Ventilação - sistema de exaustão no ambiente de seus prédios; e 
- Exaustão de Processo - sistema de exaustão para equipamentos de processo.

\subsubsection{Rejeitos e efluentes líquidos}

Qualquer rejeito ou efluente gerado no processo deve ser enviado para a Unidade de Recuperação de Urânio e Tratamento de Efluentes e Rejeitos. Depois de tratados, os efluentes são reciclados ao processo, ou enviados ao SITEA (Sistema Integrado de Tratamento de Efluentes de Aramar).

\subsubsection{Rejeitos e resíduos sólidos}

Durante a operação, são gerados resíduos e rejeitos sólidos constituídos por papel, papelão, papel alumínio, algodão, usados na descontaminação de peças, equipamentos, pisos, ou que estiverem em contato com equipamentos do processo. Anualmente a USEXA deverá gerar 151 tambores (de 200 litros) de rejeitos sólidos. Consideram-se estes tambores cheios, sem que tenha ocorrido o tratamento para imobilização de rejeitos por cimentação. Ainda haverá a geração estimada de 20 tambores por ano de resíduos sólidos (metais, materiais diversos, papel, papelão, filtros de ar, vidro, madeira, gorros, sapatilhas etc).

\subsection{Pesquisas}

Para este trabalho as pesquisas iniciaram-se com uma visita às instalações da USEXA no CEA. Posteriormente, foram coletadas informações no banco de dados da empresa, realizadas entrevistas com o pessoal técnico e gerencial e análise do Relatório Preliminar de Análise de Segurança (RPAS).

\subsubsection{Visitas}

A primeira visita realizada à USEXA foi importante para um macro conhecimento do projeto, sendo possível visualizar os prédios, os equipamentos e todo o espaço ocupado pelo empreendimento, além de possibilitar compreender os processos que compõem a planta de produção de hexafluoreto de urânio.

A segunda visita foi realizada para validação dos dados obtidos e entendimento do funcionamento da unidade de tratamento de efluentes e rejeitos. 


\subsubsection{Banco de dados histórico}

A organização possui um banco de dados, desde o início, não apenas do empreendimento, mas de toda a organização, possibilitando a coleta de informações.

Através da extração de dados, foram identificados os desembolsos efetuados com segurança ambiental. Os gastos com equipamentos de proteção individual foram excluídos por tratar-se de cumprimento à legislação trabalhista, uma vez que o objetivo deste trabalho é obter os custos ambientais do projeto.

As instalações do ciclo do combustível nuclear já tiveram algumas modificações decorrentes da própria evolução tecnológica do projeto ao longo do desenvolvimento do programa. Devido a essas alterações, muitos dados históricos ganharam outras nomenclaturas para atenderem às mudanças, e somente profissionais que acompanham o empreendimento desde o início, e possuem memória histórica dos projetos, têm a capacidade de relacioná-los e fornecer as informações necessárias para o desenvolvimento desta dissertação.

Para apuração dos gastos ambientais do projeto, foram realizadas diversas abordagens. A primeira foi calcular os desembolsos para cada unidade do projeto, mas o banco de dados não possibilitava esse procedimento. A segunda foi calcular os desembolsos de acordo com a manipulação e o processamento de composto de urânio nas formas gasosa, líquida e sólida, mas essa também não foi bem sucedida por falta desse tipo de divisão no banco de dados. Então, foi considerado o projeto inteiro e realizado os cálculos dos porcentuais dos gastos ambientais.

O critério utilizado foi relacionar os lançamentos do banco de dados com vários itens: RPAS, fornecedores, rejeitos, resíduos, efluentes, licenciamentos e tratamento de urânio.

Os dados obtidos foram baseados no valor do dólar da época, devido às mudanças de moeda e inflação que o país passou desde o início do projeto da USEXA, dessa maneira foi possível realizar o cálculo do percentual pago com o tratamento e recuperação dos rejeitos, resíduos e efluentes radioativos.

A cada coleta dos dados, os itens foram devidamente tabulados e posteriormente submetidos à especialista da área, para validação dos mesmos. Algumas informações ficaram comprometidas pela falta de detalhamento por ocasião do lançamento histórico em relação à parte ambiental. 
O banco de dados conta com 10.000 lançamentos, acumulados até o ano de 2007. Todos eles foram analisados, separados, e confrontados com especialistas da área para se chegar a um porcentual gasto com proteção ao meio ambiente em relação ao total do projeto.

\subsubsection{Entrevistas}

Foram realizadas entrevistas com as pessoas envolvidas no projeto da USEXA, a fim de validar as informações apuradas no banco de dados da empresa, obtendo-se o porcentual de gastos ambientais no total do projeto.

\subsubsection{Relatório Preliminar de Análise de Segurança}

Para o entendimento da segurança ambiental da USEXA, foi necessária a leitura do Relatório Preliminar de Análise de Segurança (RPAS). Documento que apresenta as descrições do projeto com os aspectos de segurança. $O$ documento visa demonstrar que no projeto da USEXA foram considerados os critérios necessários para assegurar que a sua operação não apresentará riscos indevidos à saúde, à segurança da população como um todo e ao meio ambiente, podendo, desta forma, receber a Licença de Construção. O relatório atende aos critérios da norma CNEN NE-1.04 /1/, que estabelece as diretrizes para 0 licenciamento de instalações nucleares. A estrutura de elaboração segue a norma CNEN NE-1.11/2/, que estabelece o modelo padrão para Relatório de Análise de Segurança de Usinas de Produção de Hexafluoreto de Urânio Natural.

\subsubsection{Gastos ambientais indiretos da USEXA}

Após o levantamento dos desembolsos relacionados com o meio ambiente no projeto USEXA, considerados como gastos diretos, também foram obtidos os gastos indiretos, aqueles que a USEXA contribui e compartilha no CEA em seus projetos ambientais.

O levantamento de dados foi obtido com as entrevistas realizadas na Coordenadoria de Infra-Estrutura e Gestão Ambiental (Engenharia atuante na Qualidade Ambiental) e no Departamento de Radioproteção e Controle Ambiental. Foram pesquisados e estimados os gastos dos principais projetos ambientais, e através de rateios, foi possível atribuir à USEXA, a sua parcela de contribuição referente ao gasto ambiental indireto. 


\section{RESULTADO E DISCUSSÕES}

Ressalta-se que uma das grandes dificuldades dos levantamentos dos gastos ambientais da USEXA foram as análises das informações. Os dados obtidos são registrados desde 1986 até 2007, dificultando a identificação por causa das alterações do sistema monetário brasileiro, mudanças no projeto da planta, e interpretação dos lançamentos no banco de dados.

Portanto, quando se busca uma fração destes gastos, ainda mais se associadas à segurança ambiental, o trabalho é realizado com uma margem de erro significativa. Mesmo assim, para avaliação final, os resultados serão apresentados com valores arredondados com duas casas decimais para facilitar o acompanhamento do raciocínio desenvolvido na obtenção dos mesmos.

\subsection{Gastos ambientais não compartilhados com o CEA}

O projeto USEXA contempla, principalmente, na sua unidade de tratamento de urânio, os gastos ambientais não compartilhados com o CEA e somente associados ao projeto da planta piloto de hexafluoreto de urânio.

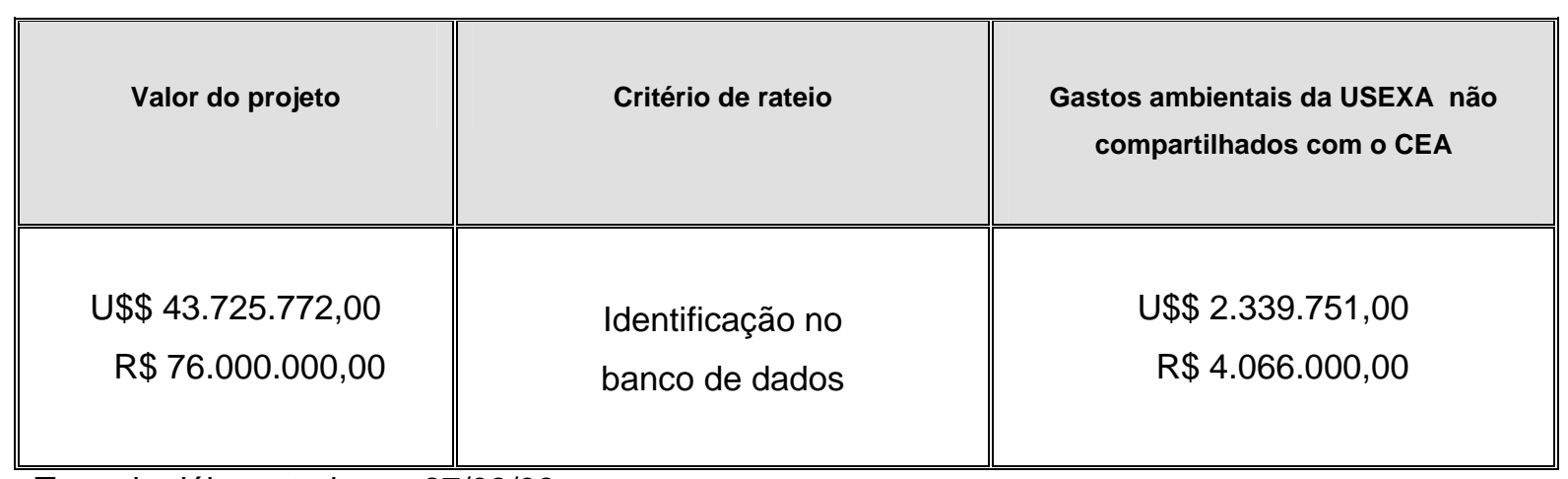

Taxa do dólar cotado em 27/03/08

Fonte: http://www5.bcb.gov.br/pec/taxas/batch/taxas.asp?id=txdolar

O critério adotado para calcular o montante dos gastos ambientais não compartilhados na USEXA foi a consulta e análise ao banco de dados históricos da empresa. Os valores foram obtidos em dólares, e depois convertidos para o real, tendo por base o câmbio da data do dia 27/03/08, fornecido pelo sistema de cotações do Banco Central. Os gastos ambientais assim calculados perfizeram o porcentual de $5,35 \%$ do total do projeto. 
Uma visão mais detalhada desta modalidade é apresentada a seguir:

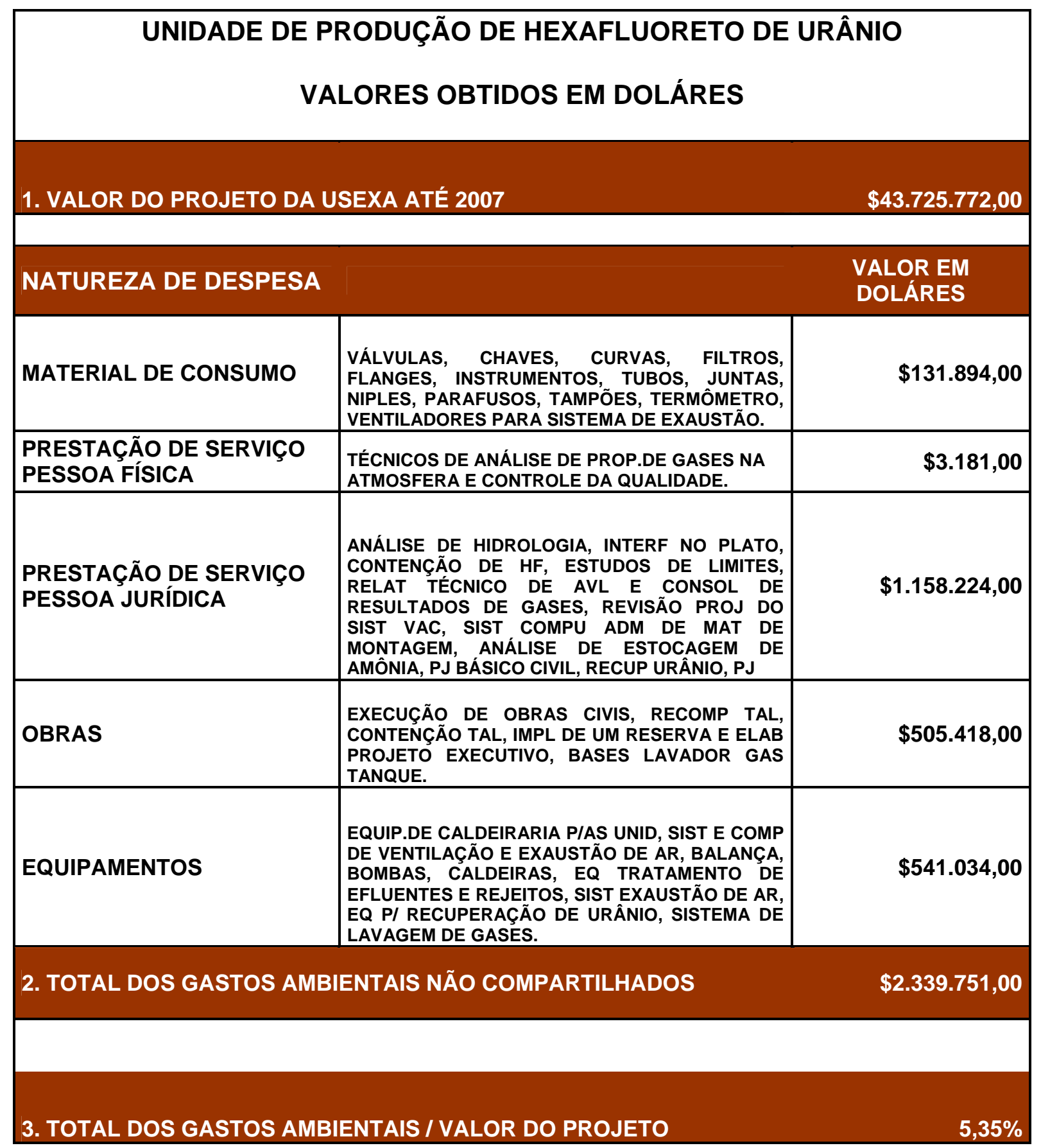




\subsection{Gastos ambientais compartilhados}

\subsubsection{EIA e RIMA}

O Estudo de Impacto Ambiental e o respectivo Relatório de Impacto Ambiental foram realizados para atender todo o Centro Experimental Aramar, sendo seu gasto compartilhado com todas as instalações nucleares existentes.

\begin{tabular}{|c||c|c||}
\hline Valor estimado & Critério de rateio & Gastos ambientais compartilhados \\
\hline \hline Cr\$ 1.770.000.000.00 & Número de instalações \\
Atualizado: $\mathrm{R} \$ 930.000,00$ & Nucleares & $\mathrm{R} \$ 186.000,00$ \\
\hline
\end{tabular}

Para fins de cálculos, não foram considerados os valores da Licença Prévia, Licença de Instalação e Audiências Públicas, o estudo foi concentrado apenas nos valores do EIA e RIMA. O valor apurado para o EIA e o RIMA foi de Cr\$ 1.770.000.000,00, na data de 18/12/1992, que, atualizado e corrigido pelo IGP-DI da FGV, através do site www.fee.tche.br, representa o montante de R\$ $930.000,00$.

O critério de rateio estabelecido para saber a contribuição da USEXA nos gastos ambientais compartilhados, foi dividir o montante apurado pelas cinco principais instalações nucleares do CEA. Vale a pena destacar que o critério adotado se justifica porque, independente do seu tamanho e/ou complexidade, qualquer uma das cinco instalações para ser licenciada necessitaria da elaboração do EIA/RIMA, por exigência da resolução CONAMA nº 001 de 23 de janeiro de 1986.

01. USEXA - Unidade de produção de hexafluoreto de urânio

02. LEI - Laboratório de enriquecimento isotópico

03. USIDE - Unidade industrial para enriquecimento de urânio;

04. LABMAT - Laboratório de materiais cerâmicos e nucleares;

05. LABGENE - Laboratório de geração núcleo-elétrica.

Valor do EIA e RIMA

Número de instalações nucleares

$$
=\frac{R \$ 930.000,00}{05}=R \$ 186.000,00
$$




\subsubsection{Sistema Integrado de Tratamento de Efluente de Aramar (SITEA)}

Levando-se em consideração o local onde o CEA está implantado e as atividades desenvolvidas, existe uma grande preocupação com a liberação dos efluentes gerados para o meio ambiente. Dessa maneira, é necessário o tratamento destes efluentes e resíduos, que permitam a sua reutilização, ou então, a liberação para o meio ambiente, dentro dos padrões exigidos. Para isso existe o SITEA, que tem a finalidade de tratar os efluentes líquidos gerados nas diversas instalações industriais do CEA.

\begin{tabular}{||c||c||c||}
\hline \hline $\begin{array}{c}\text { Valor estimado do projeto (pela } \\
\text { engenharia atuante na qualidade } \\
\text { ambiental) }\end{array}$ & Critério de rateio \\
\hline \hline $\mathrm{R} \$ 2.630 .000,00$ & Vazão $\mathrm{m}^{3} / \mathrm{dia}$ & $\mathrm{R} \$ 45.000,00$ \\
\hline
\end{tabular}

O SITEA está dimensionado para tratar até $20 \mathrm{~m}^{3}$ de efluentes por hora, tomando-se por base os regimes operacionais, demandas de águas e gerações de efluentes estabelecidas para cada empreendimento. Para a USEXA o volume diário de efluente de processo é de $8,2 \mathrm{~m}^{3}$.

O critério de rateio utilizado para se chegar à contribuição referente à USEXA dos gastos ambientais compartilhados do SITEA foi a vazão em $\mathrm{m}^{3} / \mathrm{h}$, transformada em $\mathrm{m}^{3} / \mathrm{dia}$ :

Vazão total hora $\times 24$ horas $=20 \mathrm{~m}^{3} / \mathrm{h} \times 24 \mathrm{~h}=480 \mathrm{~m}^{3} / \mathrm{dia}$

Depois foi efetuada a divisão do valor do projeto do SITEA sobre a vazão, e multiplicado pela vazão de $8.2 \mathrm{~m}^{3} /$ dia da USEXA:

Valor do SITEA $\times$ Vazão $\mathrm{m}^{3} /$ dia (USEXA) $=\underline{\mathrm{R} \$ 2.630 .000,00} \times 8.2=\mathrm{R} \$ 45.000,00$ Vazão $\mathrm{m}^{3} /$ dia 480 


\subsubsection{Lagoa de Monitoração}

O efluente tratado no Sistema Integrado de Tratamento de Efluente de Aramar é enviado a uma lagoa de monitoração, ou é reciclada nas instalações do CEA. A lagoa tem a finalidade de monitorar o efluente antes de seu lançamento no corpo receptor, sendo liberada após um controle ambiental.

\begin{tabular}{||c||c||c||}
\hline $\begin{array}{c}\text { Valor estimado do projeto (pela } \\
\text { engenharia atuante na qualidade } \\
\text { ambiental) }\end{array}$ & Critério de rateio & Gastos ambientais compartilhados \\
\hline \hline $\mathrm{R} \$ 200.000,00$ & Vazão $\mathrm{m}^{3} / \mathrm{dia}$ & $\mathrm{R} \$ 3.500,00$ \\
\hline
\end{tabular}

O critério de rateio utilizado para a contribuição da USEXA dos gastos ambientais compartilhados da Lagoa de Monitoração foi o mesmo adotado no SITEA, ou seja, a vazão em $\mathrm{m}^{3} /$ dia.

Foi efetuada a divisão do valor do projeto da lagoa sobre o efluente na vazão de $480 \mathrm{~m}^{3} /$ dia, multiplicado pela vazão de $8,2 \mathrm{~m}^{3} /$ dia da USEXA:

Valor da Lagoa $\times$ Vazão $\mathrm{m}^{3} / \mathrm{dia}=\underline{\mathrm{R} \$ 200.000,00} \times 8.2=\mathrm{R} \$ 3.500,00$ Vazão $\mathrm{m}^{3} /$ dia 480

\subsubsection{Estação de tratamento de esgoto (ETE)}

A Estação de Tratamento de Esgoto é uma unidade de tratamento que adota o processo aeróbico, com a finalidade de tratar os esgotos sanitários das instalações do Centro Experimental Aramar.

\begin{tabular}{||c||c||c||}
\hline $\begin{array}{c}\text { Valor estimado do projeto (pela } \\
\text { Engenharia atuante na qualidade } \\
\text { ambiental) }\end{array}$ & Critério de rateio & Gastos ambientais compartilhados \\
\hline \hline$R \$ 800.000,00$ & Número de instalações & $\mathrm{R} \$ 33.334,00$ \\
\hline
\end{tabular}

A contribuição da USEXA em relação aos gastos ambientais compartilhados da Estação de Tratamento de Esgoto foi o rateio do valor do 
projeto, pelo número de instalações previstas para atuarem no complexo Aramar, uma vez que a estação foi construída para atender todas as unidades, sejam elas convencionais ou nucleares.

A lista a seguir contempla as instalações convencionais e nucleares, que compõem o Centro Experimental Aramar, perfazendo o total de 24 unidades:

01. Almoxarifado;

02. Refeitório;

03. Lavanderia;

04. Enfermaria;

05. Administração;

06. LATEP - Laboratório de testes de equipamento de propulsão;

07. LARE - Laboratório radioecológico;

08. LABCHOQUE - Laboratório de choques, vibração e ruído;

09. LACEM - Laboratório de compatibilização eletromagnética;

10. OFMEPRE - Oficina mecânica de precisão;

11. LAC - Laboratório de aferição e calibração;

12. Simulador de treinamentos e testes;

13. OFCOM - Oficina de fabricação de componentes mecânicos;

14. OFTUB - Oficina de fabricação de tubulação;

15. OFCEL - Oficina de fabricação e componentes eletromecânicos;

16. OFCESP - Oficina de montagem de componentes especiais;

17. OFMEQ - Oficina de montagem de equipamento;

18. Prédios de utilidades;

19. Unidade de jateamento e pintura;

20. USEXA - Unidade de produção de hexafluoreto de urânio;

21. LEI - Laboratório de enriquecimento isotópico;

22. USIDE - Unidade industrial para enriquecimento de urânio;

23. LABMAT - Laboratório de materiais cerâmicos e nucleares;

24. LABGENE - Laboratório de geração núcleo-elétrico.

A adoção do critério de números de funcionários seria interessante, mas devido às constantes mudanças no quadro em função da descontinuidade de 
verbas, modificações no projeto e mercado de trabalho, não refletiria a situação na USEXA em plena operação.

$\frac{\text { Total do projeto }}{\text { Número de instalações }}=\frac{\mathrm{R} \$ 800.000,00}{24}=\mathrm{R} \$ 33.334,00$

\subsubsection{Rede coletora de esgoto}

A rede coletora de esgoto pertencente à ETE, faz parte do projeto que contempla o tratamento de esgoto das unidades que compõem o Centro Experimental Aramar.

\begin{tabular}{|c||c||c||}
\hline $\begin{array}{c}\text { Valor estimado do projeto (pela } \\
\text { Engenharia atuante na qualidade } \\
\text { ambiental) }\end{array}$ & Critério de rateio & Gastos ambientais compartilhados \\
\hline \hline $\mathrm{R} \$ 200.000,00$ & Número de instalações & $\mathrm{R} \$ 8.334,00$ \\
\hline
\end{tabular}

O critério de rateio adotado para mensurar a contribuição da USEXA, em relação aos gastos ambientais compartilhados da rede coletora de esgoto foi o mesmo utilizado na estação de tratamento de esgoto. Dividir o montante do projeto da rede coletora pelo número total de instalações previstas para atuarem no CEA.

$\frac{\text { Total do projeto }}{\text { Número de instalações }}=\frac{\mathrm{R} \$ 200.000,00}{24}=\mathrm{R} \$ 8.334,00$

\subsubsection{Obras de recuperação das áreas degradadas}

A recuperação das áreas degradadas é constituída do plantio de mudas nativas, incluindo árvores frutíferas, ornamentais e outras, e material para preparação de covas para o plantio das mudas como terras e adubos, além da mão-de-obra especializada. 


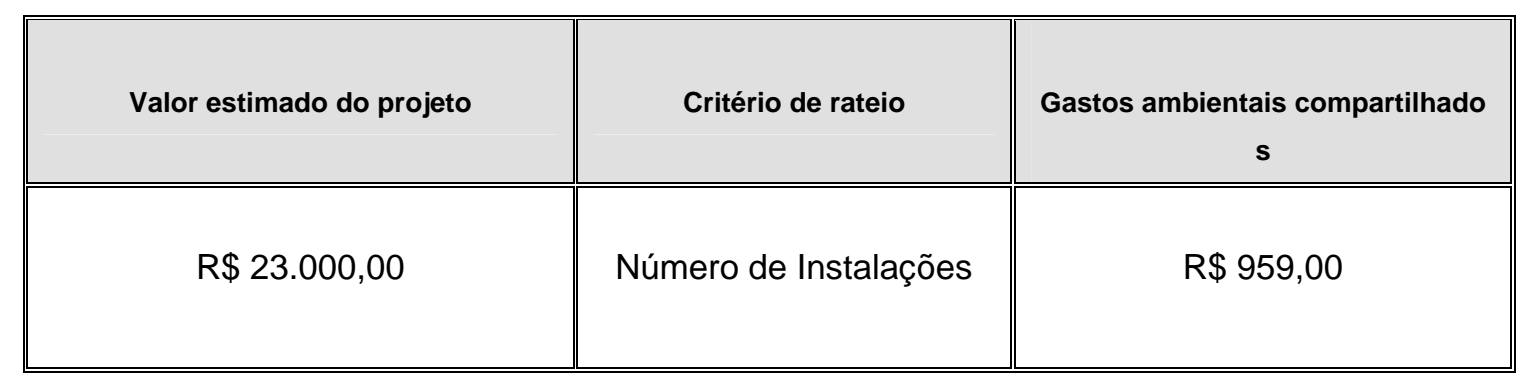

O valor estimado representa o gasto atual do projeto, considerando além da degradação ambiental causada pela ocupação humana, as degradações provocadas por queimadas, fortes chuvas, ventos e inundações.

Em grande parte a degradação das áreas são resultantes do processo de edificação da construção de instalações e, consequentemente, a recuperação está associada à própria unidade, ou seja, é de responsabilidade de todos a preservação do meio ambiente.

O critério de rateio atribuído a obras de recuperação das áreas degradadas foi dividir o montante do projeto pelo número de instalações previstas para operarem no CEA, pois todas as unidades têm a responsabilidade com o espaço ocupado.

$\frac{\text { Total do projeto }}{\text { Número de instalações }}=\frac{R \$ 23.000,00}{24}=\mathrm{R} \$ 959,00$

\subsubsection{Laboratório Radioecológico (LARE)}

Conforme RIMA (1997), as atividades da Divisão de Proteção Radiológica e Ambiental, que engloba o LARE, visam monitorar os efeitos da implantação e operação das atividades do CEA sobre o meio ambiente e prover proteção radiológica, através dos controles das liberações de material radioativos; avaliação da exposição do indivíduo do público à radiação; aferição do cumprimento das normas de radioproteção; detecção de mudanças ambientais e verificação da eficiência do tratamento de rejeitos, resíduos e efluentes. Suas atividades contemplam a coleta periódica, processamento e análise de amostras das principais vias de contaminação do homem (ar, águas de superfície, água de poços, águas das chuvas, águas subterrâneas, sedimento de fundo de rio, pasto, solo, vegetação rasteira, produtos agrícolas, peixe e leite), para determinação das concentrações de elementos radioativos. 


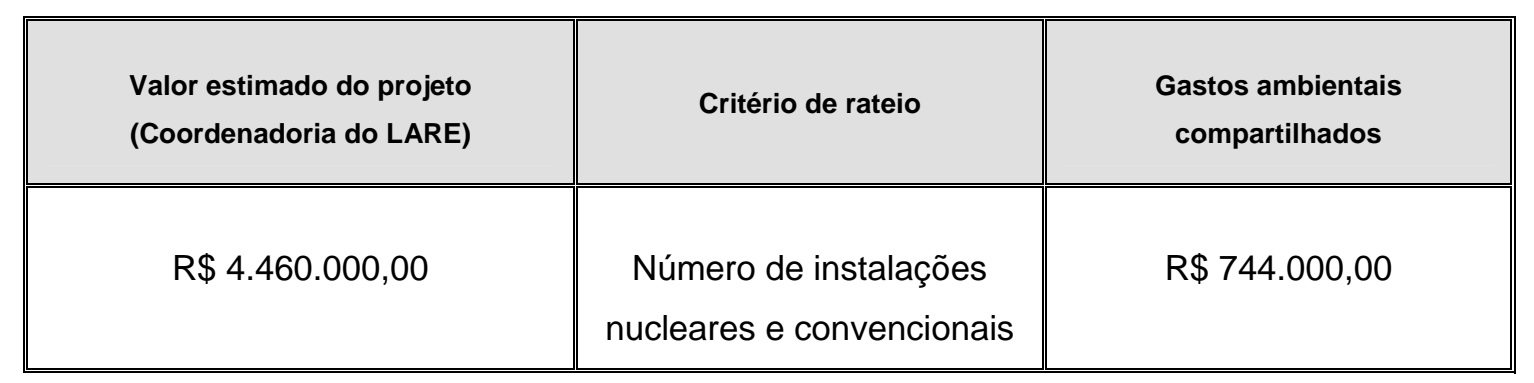

Monitorar as atividades sob o ponto de vista ambiental é uma exigência da CNEN, independente do número de instalações existentes. Portanto, o critério de rateio adotado foi dividir o valor do projeto pelo número de instalações nucleares e instalações convencionais (considerada como uma unidade) previstas para operarem no CEA, que são em número de seis:

\section{USEXA;}

02. LEl;

03. USIDE;

04. LABMAT;

05. LABGENE;

06. Instalações convencionais.

Total do projeto $=\mathrm{R} \$ 4.460 .000,00=\mathrm{R} \$ 744.000,00$

Número de instalações $\quad 06$

\subsubsection{Estação de observação meteorológica}

O controle ambiental da qualidade do ar é realizado através de uma torre meteorológica, com sensores de temperatura, velocidade e direção dos ventos, pressão, umidade e chuvas. Isso permite um acompanhamento da evolução temporal local, para fornecer suporte aos procedimentos de liberação atmosférica rotineira, emergencial e acidental das instalações do Centro Experimental Aramar. 


\begin{tabular}{|c||c||c|}
\hline $\begin{array}{c}\text { Valor estimado para equipamentos } \\
\text { (Engenharia atuante na qualidade } \\
\text { ambiental) }\end{array}$ & Critério de rateio \\
$\mathrm{R} \$ 250.000,00$ & $\begin{array}{c}\text { Número de instalações } \\
\text { nucleares }\end{array}$ & $\begin{array}{c}\text { Gastos ambientais } \\
\text { compartilhados }\end{array}$ \\
\hline \hline
\end{tabular}

Para cálculo dos custos não foram considerados os associados à manutenção e operação do projeto.

A estação é uma exigência ambiental da CNEN, uma vez que qualquer instalação nuclear necessita de monitoração permanente. Portanto havendo uma unidade ou mais no CEA, sempre existirá esta exigência. Com isso, o critério de rateio para a contribuição da USEXA em relação aos gastos compartilhados da estação de observação meteorológica foi dividir o montante do projeto pelo número das principais instalações nucleares, que são em número de cinco:

\section{USEXA;}

02. LEI;

03. USIDE;

04. LABMAT;

05. LABGENE.

Total do projeto $\equiv \mathrm{R} \$ 250.000,00=\mathrm{R} \$ 50.000,00$

Número de instalações $\quad 05$

\subsection{9. Área Verde}

O Centro Experimental Aramar está localizado em um terreno doado à Marinha do Brasil e pertencente à Fazenda Nacional Ipanema, sediada no município de Iperó.

\begin{tabular}{|c||c||c|}
\hline Valor estimado da área preservada & Critério de rateio & Ativo ambiental \\
\hline \hline $\mathrm{R} \$ 163.516 .320,00$ & Sem rateio & $\mathrm{R} \$ 163.516 .320,00$ \\
\hline
\end{tabular}


O cálculo da área verde do CEA foi realizado subtraindo a área ocupável da área total. Assim é possível saber o quanto será preservado.
(+) Área total
$=8.603 .000,00 \mathrm{~m}^{2}$
(-) Área ocupável $=\left(1.277 .000,00 \mathrm{~m}^{2}\right)$
$(=)$ Área verde $\quad=7.326 .000 \mathrm{~m}^{2}$

A cotação para um terreno na região, com área construída correspondente a 4,5\% da área total, é de $\mathrm{R} \$ 22.32$ por metro quadrado ${ }^{4}$. Este valor será adotado como o da cotação para a região. É importante ressaltar que as melhorias (construções) introduzidas no terreno aumentam o preço por metro quadrado. No caso do complexo CEA, a área ocupável é de 14,8\%, o que poderia encarecer o imóvel conforme outras cotações obtidas em outros endereços eletrônicos e com valores superiores ao adotado ${ }^{5}{ }^{6}$.

Para valorar a área verde do CEA, multiplicou-se o valor do metro quadrado pela área verde preservada: $7.326 .000 \mathrm{~m}^{2} \times \mathrm{R} \$ 22,32=\mathrm{R} \$$ 163.516.320,00.

Neste caso, o ativo é considerado como um todo, evitando-se a fragmentação entre as diferentes unidades do CEA. A sustentabilidade ganha maior significado quando a área preservada pode abrigar maior diversidade em conseqüência de sua maior extensão. Por questão de princípio, não foi feito o fracionamento da natureza, o que acarreta a incorporação do ativo no projeto USEXA, embora apresentado à parte.

\subsection{Balanço Ambiental}

O Balanço Ambiental, que procura demonstrar o quanto a empresa está investindo no meio ambiente, é apresentado na forma resumida na TAB. 04.

\footnotetext{
${ }^{4}$ Fonte: http://www.estanciaimoveis.com.br/os/-p-285.html

${ }^{5}$ Fonte: http://produto.mercadolivre.com.br/MLB-70186948-chacaras-em-sorocaba-ipero

${ }^{6}$ Fonte: http://www.portaldasimobiliarias.com.br
} 
TABELA 4 - Balanço Ambiental da USEXA

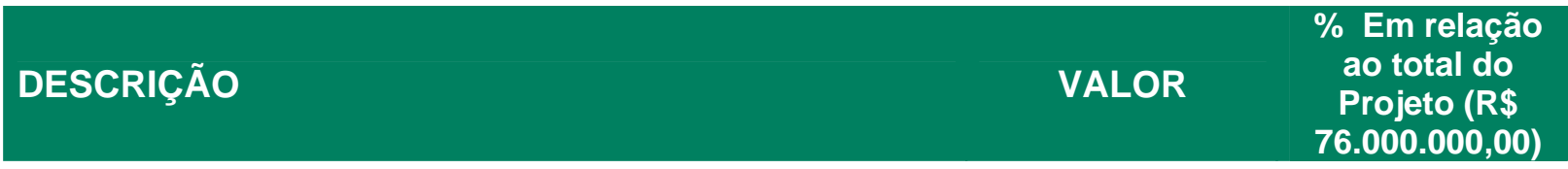

1 Gastos Ambientais

Não Compartilhados

\begin{tabular}{llrr} 
& & $\mathbf{R} \mathbf{4 . 0 6 6 . 0 0 0 , 0 0}$ & $\mathbf{5 , 3 5 \%}$ \\
\hline & EIA RIMA & $R \$ 186.000,00$ & $0,24 \%$ \\
\cline { 2 - 4 } & SITEA & $R \$ 45.000,00$ & $0,06 \%$ \\
\cline { 2 - 4 } & Lagoa de Monitoração & $R \$ 3.500,00$ & $0,00 \%$ \\
\cline { 2 - 4 } $\begin{array}{l}\text { Gastos Ambientais } \\
\text { Compartilhados }\end{array}$ & ETE & $R \$ 3.334,00$ & $0,00 \%$ \\
\cline { 2 - 4 } & Rede coletora de esgoto & $R \$ 8.334,00$ & $0,01 \%$ \\
\cline { 2 - 4 } & Recuperação das áreas degradadas & $R \$ 959,00$ & $0,00 \%$ \\
\cline { 2 - 4 } & LARE & $R \$ 744.000,00$ & $0,98 \%$ \\
\cline { 2 - 4 } & Estação de observação meteorológica & $R \$ 50.000,00$ & $0,07 \%$ \\
\hline
\end{tabular}

3 Total $(1+2)$

R\$ 5.107.127,00

$6,72 \%$

4 Ativo Ambiental

(Áreas Verdes Preservadas) 


\section{CONCLUSÕES}

O presente trabalho estudou os gastos ambientais da Unidade de Produção de Hexafluoreto de Urânio, mais conhecida como USEXA. Empreendimento que vem sendo desenvolvido no Centro Tecnológico da Marinha em São Paulo, instalada no Centro Experimental Aramar no município de Iperó, $\mathrm{SP}$.

As porcentagens obtidas da integração dos gastos, ao longo de mais de 20 anos, mostram um valor de $6,72 \%$ do total previsto para o empreendimento. Este resultado é um número puro, uma vez que não foram considerados os desembolsos com equipamentos de proteção individual, que foram excluídos por tratar-se de legislação trabalhista, e o objetivo deste estudo foi obter os gastos ambientais do projeto. A porcentagem de $6.72 \%$ é um valor orientador que pode ser adotado em de mesma natureza.

Outro fator a ser destacado é o ativo ambiental representado pela área preservada no CEA que, segundo conceito da IBRACON, significa uma valorização da própria região onde o empreendimento se insere, ou uma externalidade positiva na qual a empresa adiciona benefícios independente das transações mercadológicas (Philippi, 2004) e que, segundo Silva, pode ser apresentado no Balanço Social como um fator diferencial de competitividade (Silva, 2003). Ressalta-se que, no Brasil, de acordo com Oliveira \& Maciel, a Contabilidade Ambiental está em processo de evolução, o que abre inúmeras possibilidades para sua discussão, pois esta prática ainda não está regulamentada (Oliveira \& Maciel, 2008).

Assim, curiosamente, o maior patrimônio da USEXA, ou do próprio CEA, é a sua área preservada que, em termos mercadológicos, representa mais de $200 \%$ do valor do empreendimento industrial, motivo de orgulho para qualquer instituição que tente se adequar aos tempos modernos, nos quais a preservação ambiental é uma questão crucial. Hoje em dia, o consumidor brasileiro, em mais de 52\%, opta por produtos ambientalmente corretos em detrimento de outros não corretos. Há previsão, segundo o mesmo estudo, de que rapidamente $78 \%$ dos consumidores terão esta mesma postura (Ibope, 2007). 


\section{REFERÊNCIAS BIBLIOGRÁFICAS}

AGENCIA FAPESP. Fundação de Amparo à Pesquisa do Estão de São Paulo. Vista aérea do CTMSP no campus do IPEN. 1 fotografia, color. Disponível em: <www.agencia.fapesp.br>. Acesso em: 01 abr. 2007.

BARBIERI, J.C. Gestão ambiental empresarial: conceitos modelos e instrumentos. São Paulo: Saraiva, 2007.

BBCNEWS. The Nuclear Fuel Cycle. Yellow Cake. 1 fotografia, color. Disponível em:

<http://news.bbc.co.uk/1/shared/spl/hi/sci_nat/05/nuclear_fuel/html/conversion.stm >. Acesso em: 25 jul. 2007.

BRASIL. Ministério da Defesa. Centro Tecnológico da Marinha em São Paulo CTMSP. Apresenta texto sobre o Centro Tecnológico da Marinha em São Paulo. Disponível em: <http://www.mar.mil.br/ctmsp>. Acesso em: 11 fev. 2006a.

BRASIL. Ministério da Defesa. Centro Tecnológico da Marinha em São Paulo CTMSP. Ordem Interna $\mathrm{n}^{\circ}$ 01/2006. Aniversário do Centro Tecnológico da Marinha em São Paulo. São Paulo, 2006b.

BRASIL. Ministério da Fazenda. Banco Central do Brasil. Apresenta cotação de fechamento de dólar. Disponível em: <http://www5.bcb.gov.br/pec/taxas/batch/taxas.asp?id=txdolar>. Acesso em: 27 mar. 2008.

BRASIL. Ministério de Minas e Energia. Agência Nacional de Energia Elétrica. Apresenta texto sobre capacidade energética. Disponível em: < http://www.aneel.gov.br/>. Acesso em: 20 jun. 2007.

BRESCIASCIENZA. Giroscópio. 1 fotografia, color. Disponível em: <www.bresciascienza.it/.../cult/science_shop.htm>. Acesso em: 01 abr. 2008.

CASSEDY, E.S.; GROSSMAN, P.Z. Introduction to energy. Resources, technology and society. Cambridge University Press, 1990.

CENTRO EXPERIMENTAL ARAMAR. Relatório de impacto ambiental - RIMA. Setembro, 1997.

CNEN. Comissão Nacional de Energia Nuclear. Apresenta texto sobre atividades. Disponível em: <http://www.cnen.gov.br/acnen/atividades.asp>. Acesso em: 20 Jan. 2008. 
COCHRAN, R.G; TSOULFANIDIS,N. The Nuclear fuel cycle: analysis and manangement. Illinois: American Nuclear Society, 1992.

COLEGIOSAOFRANCISCO. Colégio São Francisco. Minério de urânio. 1 fotografia, color. Disponível em: <http://www.colegiosaofrancisco.com.br/alfa/energia-nuclear/minerio-deuranio.php>. Acesso em: 25 mar. 2008.

CONSELHO FEDERAL DE CONTABILIDADE. Norma Brasileira de Contabilidade NBC-T-03. Conceito, conteúdo, estrutura e nomenclatura das Demonstrações Contábeis. Brasília: CFC, 1991.

DANTAS, V. A verdade sobre os rejeitos nucleares. Brasil Nuclear. n. 31, p.1521, 2007.

DE LUCA, M.M.M. Demonstração do valor adicionado: do cálculo da riqueza criada pela empresa ao valor do PIB. São Paulo: Atlas, 1998.

DONAIRE, D. Gestão ambiental na empresa. São Paulo: Atlas, 1999.

ENERGY indicators for sustainable development: guidelines and methodologies. Vienna: International Atomic Energy Agency, 2005.

ESTÂNCIA IMÓVEIS. Apresenta texto sobre venda de sítio em Iperó. Disponível em: <www.estanciaimoveis.com.br/os/-p-285.html>. Acesso em: 18 abr. 2008

FONSECA, E. O Brasil rumo à auto-suficiência energética e mineral. Ministério das Minas e Energia. São Paulo: Hanna e Amorim Serviços Especiais de Comunicação, 1990.

GIL, A. C. Como elaborar projetos de pesquisa. São Paulo: Atlas, 2002.

GLASSTONE, S; SESONSKE. A. Ingenieria de reactores nuclears. Madrid, 1975.

GODOY, A.S. Introdução à pesquisa qualitativa e suas possibilidades. Revista de Administração de Empresas. v. 35, n. 2, p.57-63, 1995.

GOOGLEEARTH. Google Earth. Vista aérea da Unidade de Produção de Hexafluoreto de Urânio (USEXA). 1 fotografia, color. Disponível em: <http://earth.google.com/intl/pt/>. Acesso em: 01 mar. 2008. 
GRIPPI, S. Energia Nuclear. Os bastidores do programa nuclear brasileiro e seus reflexos na sociedade e na economia nacional. Rio de Janeiro: Interciência, 2006.

HAMMOND, A.L; METZ, W.D, MAUGH II, T.H. Energy and the future. American Association for the Advancement of Science. Washington, 1973.

HARRINGTON, C. D \& RUEHLE, E. Uranium production techonology. New Jersey, Van Nostrand, 1969.

IBAMA. Instituto Brasileiro do Meio Ambiente e dos Recursos Naturais Renováveis. Apresenta texto sobre licenciamento ambiental federal. Disponível em: <http://www.ibama.gov.br/institucional/historia/index.htm>. Acesso em: 20 Jan. 2008.

IBOPE - Instituto Brasileiro de Opinião Pública e Estatística. Sustentabilidade: hoje ou amanhã. In: FÓRUM IBOPE, 2., 2007, São Paulo. Negócios sustentáveis. São Paulo, 2007.

IBRACON - Instituto dos Auditores Independentes do Brasil. NPA-11. Balanço e ecologia. São Paulo: IBRACON, 1996.

INB. Indústrias Nucleares do Brasil. Lixiviação, ciclo da conversão, dióxido de urânio, pastilha de dióxido de urânio, elemento combustível e usina em Caetié. 6 fotografias, color. Disponível em: <www.inb.gov.br>. Acesso em: 25 jul. 2007.

INTERNATIONAL ATOMIC ENERGY AGENCY. Country nuclear fuel cycle profiles. Vienna: IAEA, 2001. (Technical Report, $\left.n^{\circ} 404\right)$.

IPEA. Instituto de Pesquisa Econômica Aplicada. Uso de instrumentos econômicos na gestão ambiental da América Latina e Caribe: Lições e Recomendações. Rio de Janeiro, 1996.

ISHIGURO, Y. A energia nuclear para o Brasil. São Paulo: Makron Books, 2002.

IZIQUE. C. O desafio da competitividade. Marinha pleiteia recursos do BNDES para aprimorar tecnologia de enriquecimento de urânio. Revista Pesquisa FAPESP. n. 101, 2004.

IUDÍCIBUS, S. de.; MARTINS, E.; KANITZ, S.C.; RAMOS, A. de T.; CASTILHO, E.; BENATTI, L.; WEBER FILHO, E.; DOMINGUES JÚNIOR, R. Contabilidade introdutória. São Paulo: Atlas, 1996. 
KRAEMER. M.E.P. Contabilidade Ambiental como sistema de informações. Revista Brasileira de Contabilidade. n. 133, p. 69-82, 2002.

MARTINS, E. Contabilidade de custos. São Paulo: Atlas, 1998.

MAY, P.H.; LUSTOSA, M.C.; VINHA,V. Economia do meio ambiente. ECONOMIA DO MEIO AMBIENTE. São Paulo: Campus, 2003.

MERCADO LIVRE. Apresenta texto sobre venda de chácara em Iperó. Disponível em: <produto.mercadolivre.com.br/MLB-70186948-chacaras-em-sorocaba-ipero>. Acesso em: 18 abr. 2008.

MIGGO. Instalações nucleares de Angra 1. 1 fotografia, color. Disponível em: < Fonte: $\quad$ http://www.miggo.com.br/clientes/eletronuclear/index.php?tipo=Fotos $>$. Acesso em: 15 set. 2007.

MOTTA, R.S. Economia ambiental. Rio de Janeiro: FVG, 2006.

MOURA, L.A.A. de. Qualidade e gestão ambiental. São Paulo: Juarez de Oliveira, 2002.

MOURA, L.A.A. de. Economia ambiental: gestão de custos e investimentos. São Paulo: Juarez de Oliveira, 2003.

MOREIRA, E. M.; UDAETA, M. E. M.; GRIMONI, J. A. B. Energia nuclear e mecanismo de desenvolvimento limpo no planejamento energético. In: Congresso Brasileiro de Planejamento Energético, 4. 2004. Minas Gerais.. Minas gerais, 2004.

MURRAY, R.L. Energia Nuclear. Uma introdução aos conceitos, sistemas e aplicações dos processos nucleares. Brasil: Hemus, 2004.

OLIVEIRA, K.R.; MACIEL, L.E.S. Contabilidade ambiental como fonte de aplicação de recursos em projetos ambientais. Boletim CRC SP, n. 165, p. 16-21, 2008.

ONU - Organização das Nações Unidas no Brasil. Mundo deve ter 10 bi de habitantes em 2050. 25 jul. 2005. Disponível em: <http://www.onubrasil.org.br/view_news.php?id=2628>. Acesso em: 28 abr. 2008.

PHILIPPI JR, A.; ROMÉRO, M. de A.; BRUNA, G. C. Curso de gestão ambiental. São Paulo: Manole, 2004. 
PINTO, A.L.; RIBEIRO, M. de S. R. O Balanço Social como instrumento de evidenciação de responsabilidade social: um estudo no estado de Santa Catarina.

Revista Brasileira de Contabilidade. n. 154, p. 37-49, 2005.

PORTAL DAS IMOBILIÁRIAS. Apresenta textos sobre venda de chácara em Iperó. Disponível em: <www.portaldasimobiliarias.com.br>. Acesso em: 16 abr. 2008.

PORTAL DE CONTABILIDADE. Apresenta texto sobre o que é contabilidade ambiental. Disponível em: <http://www.portaldecontabilidade.com.br/tematicas/contabilidadeambiental.htm>. Acesso em: 28 jul. 2006.

RIBEIRO, M. de S.R. Contabilidade ambiental. São Paulo: Saraiva, 2005.

RIBEIRO, M. de S; LISBOA, L.P. Balanço Social: Instrumento de divulgação da interação da empresa com a sociedade. Anais do $23^{\circ}$ ENANPAD. Ribeirão Preto: USP, 1999.

RIO GRANDE DO SUL. Secretaria de Planejamento e Gestão. Fundação de Economia e Estatística. Atualização de valores, através do Indice Geral de Preços-Disponibilidade Interna (IGP-DI) da Fundação Getúlio Vargas. Disponível em: <http://www.fee.tche.br/sitefee/pt/content/servicos/pg_atualizacao_valores.php>. Acesso em: 01 abr. 2008.

ROSE, R. Legislação e normas ambientais na América Latina. São Paulo: COMPAM, 2001. Disponível em <http://www.compam.com.br/artigo_america2.htm>. Acesso em: 22 mar. 2007.

ROSA, L. P. Geração hidrelétrica, termelétrica e nuclear. Estudos Avançados, São Paulo, v.21, n.59, jan./abr. 2007. Disponível em: <http://www.scielo.br/scielo.php?script=sci_arttext\&pid=S01034014200700010000 5\&lng=\&nrm=iso\&tlng=>. Acesso em: 23 mar. 2008.

SEMINÁRIOS temáticos para a 3a . Conferência Nacional de Ciência, Tecnologia e Inovação. Parcerias Estratégicas, Brasília, DF, n.20, jun. 2005

SHREVE, R.N.; BRINK JR, J.A. Indústrias de processos químicos. Guanabara: Koogan, 1977.

SILVA, B.G. da. Contabilidade geral para concursos. São Paulo: Meta, 1992. 
SILVA, B.A. Contabilidade e meio ambiente. Considerações teóricas e práticas sobre o controle dos gastos ambientais. São Paulo: Annablume, 2003.

SILVA, O. L. P. da; MARQUES, A. L. F. Esquema de ultracentrífuga. 1 ilustração, color. Economia \& Energia, ano 10, n.54, fev./mar. 2006. Disponível em: <http://ecen.com/eee54/eee54p/enriquec_uranio_brasil.htm>. Acesso em: 20 jun. 2008.

SLOMSKI, V. Mensuração do Resultado Econômico em Entidades Públicas: uma proposta. 2006. Dissertação (Mestrado) - Universidade de São Paulo, São Paulo.

SUAPESQUISA.COM. Poluição do ar: fontes de poluição, efeito estufa, chuva ácida, combustíveis fósseis, conseqüências da poluição, combustíveis não poluentes, poluição ambiental e poluição atmosférica. Disponível em: <http://www.suapesquisa.com/poluicaodoar>. Acesso em: 24 jul. 2006.

TERRITORIOSCUOLA. Reservas brasileira de urânio. 1 fotografia, color. Disponível em: <www.territorioscuola.com>. Acesso em: 25 mar.2008.

TINOCO, J.EP.; KRAEMER.M.EP. Contabilidade e gestão ambiental. São Paulo: Atlas, 2004.

THE FUTURE OF NUCLEAR POWER. An Interdisciplinary Mit Study. Massachusetts, 2003.

THE NUCLEAR FUEL CYCLE. Australian Uranium Association. Information papers, 2007. Disponível em: <http://www.uic.com.au/nip65.htm>. Acesso em: 13 abr. 2007

WAKIL, M.M. EL. Nuclear Energy Conversion. New York: Intext Educational Publishers, p. 145, 1971.

WCED (World Commission on Environment and Development). Our Common Furute. Oxford, UK: Oxford Universtiy Press, 1987.

WEGWEISER. Made in Germany. de. Usinas nucleares de Angra 1 e 2. 1 fotografia, color. Disponível em: <http://www.wegweiser.de/cps/wegweiser/home.php>. Acesso em: 15 jun.2008.

WILSON, P.D. The Nuclear Fuel Cycle from ore to wastes. New York: Oxford University Press, 1996. 


\section{BIBLIOGRAFIA RECOMENDADA}

IGAMI, M.P.Z. Guia para elaboração de dissertação e teses. São Paulo: IPEN, 2002.

IZIQUE. C. O submarino que dá luz. Programa terá R\$ 1 bilhão para o reator que também servirá à geração elétrica. Revista Pesquisa FAPESP. n. 139, 2007.

LIMA, D.V. O ciclo do combustível nuclear. Ciclo de palestras do PROINFO. 1988.

MARION, J.C. Contabilidade empresarial. São Paulo: Atlas, 2005.

RIBEIRO, M. de S.; GRATÃO, A. D. Custos ambientais: o caso das empresas distribuidoras de combustíveis. In CONGRESSO BRASILEIRO DE CUSTOS, 7, 2000, Recife. Anais do VII Congresso Brasileiro de Custos. Recife: PE, 2000. 


\section{CURRICULUM VITAE}

\section{IDENTIFICAÇÃO}

Cintia Nagako Komatsu

Rua Lourenço Prado, 209

CEP 05596-150

Telefone com (11) 3817-7129

Telefone cel (11) 9529-3608

E-mail: nagako@ig.com.br

\section{FORMAÇÃO}

Bacharel em Ciências Contábeis

Instituição: Faculdade de Ciências Econômicas e Administrativas (FAC-FITO)

Especialização em Gestão de Negócios

Instituição: Instituto de Paulista de Ensino e Pesquisa (IPEP)

Mestrado em Tecnologia Nuclear - Materiais

Instituição: Instituto de Pesquisas Energéticas e Nucleares (IPEN/USP)

\section{ÁREAS DE ATUAÇÃO}

Área Financeira

Contabilidade Pública

Contabilidade de Custos

Ciências Ambientais

Docência de $2^{\circ}$ e $3^{\circ} \mathrm{Grau}$ 